QL

677.2

L58

1914

Birds

\title{
HANDBOOK AND GUIDE
}

\section{BRITISH BIRDS}

\author{
ON EXHIBITION IN
}

THE LORD DERBY NATURAL HISTORY

MUSEUM, LIVERPOOL.

ILLUSTRATED BY TWELVE PLATES AND PLAN OF ARRANGEMENT.

LIVERPOOL :

C. TINLING \& CO., LTD.. 53, VICTORIA STREET. 
(1)

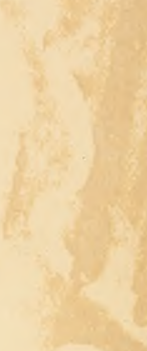

39.

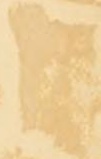

7n: 1

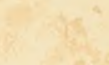

s.t.

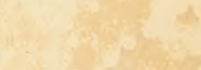









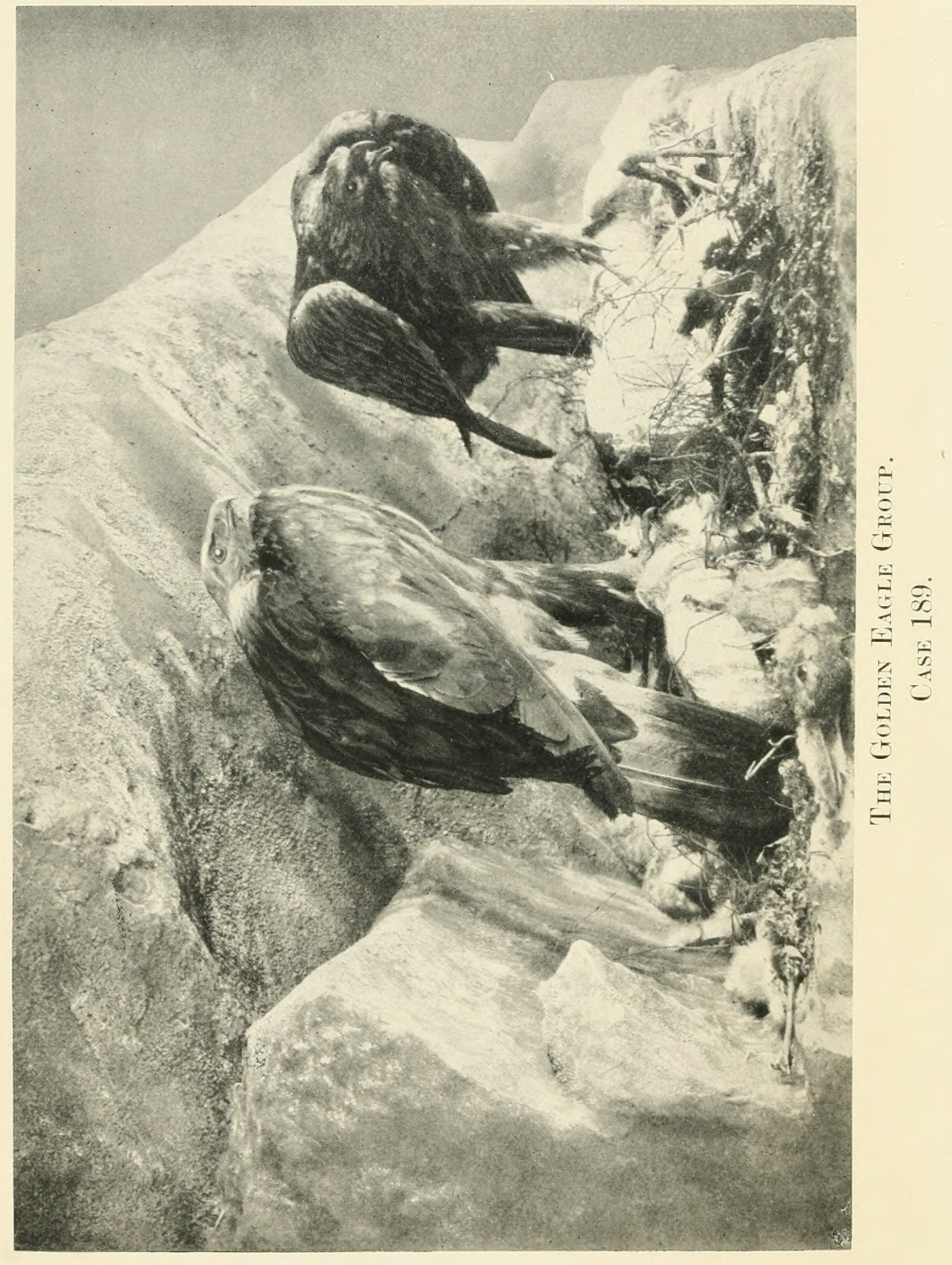




\section{HANDBOOK AND GUIDE}

TO THE

\section{BRITISH BIRDS}

ON EXHIBITION IN

THE LORD DERBY NATURAL HISTORY

MUSEUM, LIVERPOOL.

ILLUSTRATED BY TWELVE PLATES AND PLAN OF ARRANGEMENT.

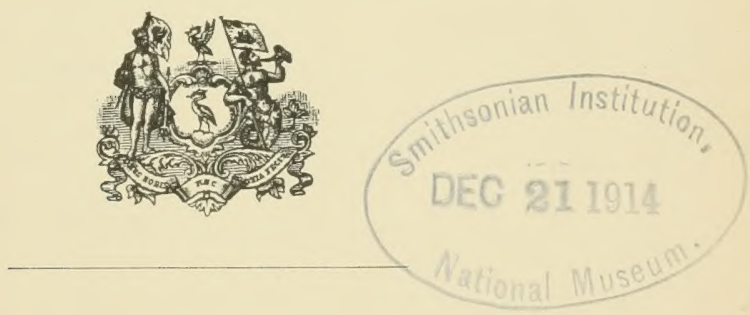

LIVERPOOL :

C. TINLING \& CO., LTD., 53, VICTORIA STREET. 



\section{O N T E N'I'S.}

PACF

Introduction

V.

Description of British Birds (exhibited with natural surroundings)............. 1

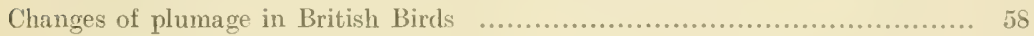

Domesticated Birds ......................................................... 58

The British Birds' Egg Collection ........................................ 59

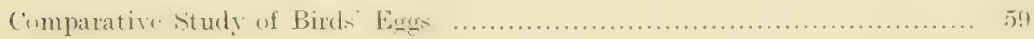

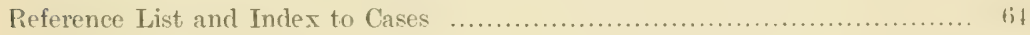


With the Curator's Compliments.

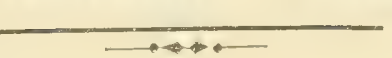




\section{LIST OF TILLESTRATTONS.}

\section{The Plates are reproduced from the Groups in the Gallery.}

The (4) liten Easle

Frontispiere.

Plan of the arrangement of cases in British Bird Gallery To face page 1

The Hooded or Grey Crow

, Ruff

, Dipper and Pied Wagtail

,. Kingfisher

.. Curckin)

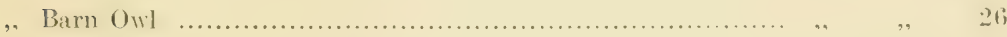

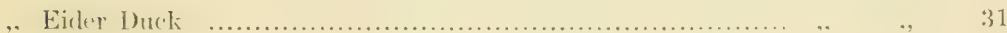

., Orster Catcher ........................................ .. . $\quad 33$

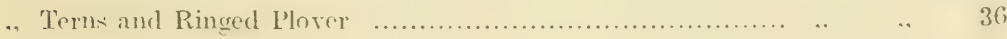

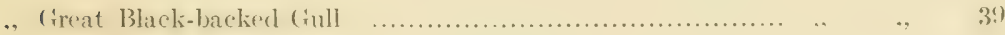

, Black-throated Diver ....................................... , , , 42 



\section{PREFA C E.}

The Liverpool IInsenm was the first institution of its lind in Cireat Britain, if not in the world, to place on exhibition a case showing a species of Bird mounted with a representation of its habitat. This was in the year 1865, and the group, that of the Bald cont. Was exhibiterl at the British Association Meeting held in Birminghan. the same year. It is still in existence and because of its historical interest is placed on exhibition.

Considerable advances in technical detail have been made since then, and the collection now possesses a latge number of highly educational and artistic groups mounted on this principle, the work on which has all been done in the Museum. The Committee has been fortunate in possessing on the staff an artist in taxidermy, the present Head Taxidermist and Assistant in Vertebrate \%oology. Mr. .J. W. C'utmure. and I have pleasure in acknowledging his skill in this work.

This little booklet is on the lires of the British Museum Guicie. from which much useful help has been received.

I hope that this "Guide and Handbook," will serve not only as a useful companion to the visitor while in the Musemm Gallery hut also as an instructive and interesting handbook for future reference.

JOSEPH A. CLUBB,

Curator of Museums.

Free Public Museuns,

Liverpool, Jamuary, 1914. 



\section{N'TRODUCTION.}

The latest list of British Birds contains about 400 species. But opinion differs much as to the number which should be allowed to rank as British. Birds are not subject to physical barriers, such as affect mammals, reptiles or fresh water fishes, and their lankis are constantly reinforced by migrants from the continent and eren from the far distant shores of America. Thus in addition to the resident spece iles and anmual

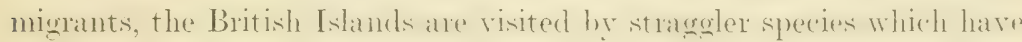
been blown out of their course on migration - so that birds which have occurred but once may be included in the British List, and others are doubtful as not sutticiently anthenticater. of the total number about 130 are residents (species that breed and are found in this country throughout the rear), alwut 5.) arre regular summer visitors or mignatory birds which breed here, about 70 are spring and autumn migrants, and winter visitor's which do not hreed here. the remainder being rare and accidental wanderers.

The following lists of these respective groups, omitting the rare and accidental visitors, may be useful. All birds that may be found throughont the year in some part of the British Islands are included in the "Resident" list, but it is open to question whether certain of these. of which the main body is migratory, should be so regarded.

\section{A.-RESIDENT BIRDS.}

Included in this list are all species of which representatives remain throughout the year in some part or other of the British Islands. Certain of these species have their numbers greatly angmented at certain times in the year by visitors from the continent.

Blackbird

Bullfinch

Bunting, Cirl

, Corn

,$\quad$ Reed

"Yellow

Buzzard, Common
Capercaillie

Chaffinch

Chough

Coot

Cormorant

Crossbill
Green (Shag) 


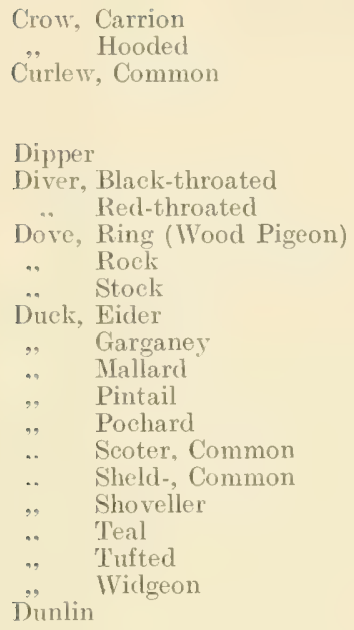

Eagle, Golden

Falcon, Peregrine

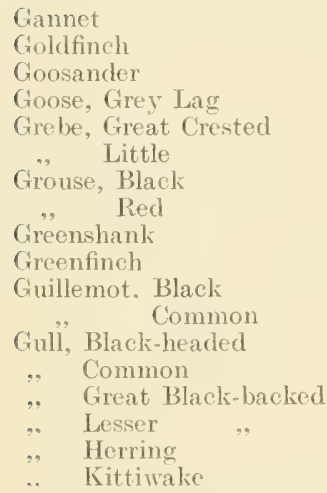

Hawfinch

Hawk, Sparrow

Harrier, Hen

Heron, Common

Jackdaw

Jay
Kestrel

Kingfisher

Kite, Common

Lapwing (Peewit)

Lark, Sky

, Wood

Linnet

Magpie

Merganser, Red-breasted

Merlin

Ioorhen

Nuthatch

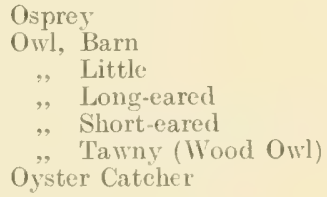

\section{Partridge, Common \\ ", Red-legged}

$$
\text { .. Ieach's Fork-tailed }
$$$$
\text { , Storm }
$$

Pheasant.

Pipit, Meadow

$$
\text { , Rock }
$$

Plover. Golden

Ptarmigan

\section{Rail, Water}

Raven

Razorbill

Redpoll, Lesser

Redshank

Robin

Rook

Shearwater, Manx

Siskin

Skua, Aretic or Richardson's

Great

Snipe, Common

Sparrow, Hedge

, House 
Starling

Stonechat

Sivan, Mute

Thrush, Mistle

Tit, Bearded

, Blue

. Cral

, Crested

, Great

" Long-tailed

, Marsh
'T'ree Creeper

'Twite

Wagtail, Grey

Warbler, Dartford

Woodecels

Woodpecker, Great Spotted

Lesser

., Golden Crested

\section{B.-MIGRATORY BIRDS.}

(a) Summer Visitors.

Includes all species which visit the British Islands for nesting purposes.

Blackeap

Bittern, Little

Buzzard, Honey

\section{Chiffchaff}

Corncrake (Landrail)

Crake, Spotted

Cuckoo

Curlew, Stone

Dotterel

Dove, 'Turtle

Flycatcher, Spotted

$$
\text { , Pied }
$$

Garganey

Grebe, Black Necked or Eared

Harrier, Montague's

Hobby

Martin, House
, Sand

Nightingale

Nightjar

Oriole, Golden

Osprey

Ouzel, Ring
Phalarope, Red-necked

Pipit, Tree

Plover, Kentish

Puffin

Quail

Redstart

Sandpiper, Common

Shrike, Red-backed

Swallow

Swift

'I'ern, Aretic

., Black

, Caspian

., Common

" Gull-billed

, Little

", Roseate (rare)

" Sandwich

Wagtail. Blue-headed

, Yellow

, White

Warbler, Garden

" Grasshopper

"Narsh

, Savi's

" Sedge

" Reed

, Willow

Wood

Wheatear

Whinchat

Whitethroat

Whiminel

Lesser

IVryneck 
viii.

(b) Winter Visitors and Passing Wigrants.

Inclurles the pergular winter visitors and migrants making a short star in the British Islands on their autumn and spring passage.

Auk, Little

Avocet

Bittern

Brambling

Bunting, Lapland

. Ortolan

.. Snow

Buzzard, Rough-legged

Crake, Little

.. Baillon's

Duck, Ferruginous

.. Gadwall

,Golden-eye

, Long-tailed

,. Scoter, Velvet

Scaup

Diver, Great Northern

Eagle, White-tailed

Falcon, Greenland

Fieldfare

Eirecrest

Goose, Bean

, Bernacle

, Brent

, Pink-footed

, IVlite-fronted

Godwit, Black-tailed

Bar-tailed

Grebe, Red-necked

Goshaw k

Sclavonian

Grosbeak, Pine

Gull, Glaucous

.. Irory

Iceland

. Little
Hoopoe

Harrier, Marsh

Knot

L.ark, Shore

Nuteracker

$$
\begin{array}{cl}
\text { Owl, Scops } \\
,, & \text { Snowy } \\
, & \text { Tengmalm's }
\end{array}
$$

Pastor, Rose-coloured

Phalarope, Grey

Pipit, Scandinavian Rock

Plover, Grey

Pratincole

Redpoll, Mealy

Redstart, Black

Redwing

Redshank, Spotted (Dusky)

Ruff

Sanderling

Sandpiper, Green

, Wood

, Purple

Curlew

Shrike, Great Grey

Snipe, Great

Jack

Smew

Skua, Pomatorhine

Stint, Little

Temminck's

Swan, Bewick's

.. IVhooper

Turnstone

Waxwing

The Lancashire and Cheshire records contain about 260 species, so that about 1:30 speries rended in other parts of the British Isles hatre not been seen in this neighbourhood. Of this total the resident species 
number about 8 .; the summer visitors or migratore birds which beed about 31 , the winter visitants and migrants making a short star on their autumn and spring passage, but do not breed here, about 77 , the remainder being stragglers or occasional visitors.

In the British Birl Gallery all mestimy birds of the meinhtomblomel. together with species common in other parts of the Britinl Islindis. are mounted with nests and natural surroundings and in the following

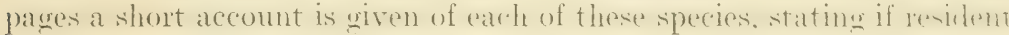
or summer migrant, the character of country frepuented, mat ure of foust. colonir of egess and number of clutrh, character of nest and ot her arhlit innal points of interest.

The winter migrants and species that have only been recorded on rare occasions are on exhibition. Some of these latter such as the Collared Pratincole, which is the first recorted sperimen in Britain, ane of special interest.

A case is added illustrating the changes in plumage of many birds according to age and season; also a case of domesticated birds.

In addition to a cabinet of British Bird's Eggs there is a case illustrating many interesting facts connected with egg structure, texture, colour, form, etc. 




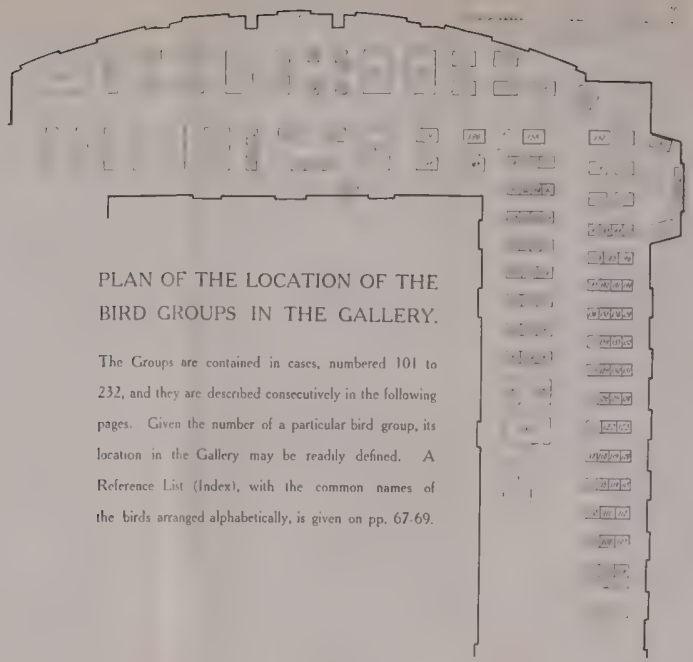



wool, amd is huilt in a tree or on a ledge of rock. The egrgs (see British Bircl Egg ('abinet, drawer (6) are from four to five in number and closely resemble those of the Rook and Hooded Crow. The food comsists of small mammals, birds and egus, and all sorts of rarron and refuse. Creat. damage is done in game preserves by the deprediations of these crows.

\section{Case 102.}

HOODED oR GREY CROIV (Corvus cornix).

Local names: Royston Crow, Sea Crow.

The Rosston ('row, as this spexcies is also called, visits England and IVales from Or.tober onwards in larese numbers, while in the north and west of Scotland and in Ireland it is resident. Its favourite food seems to consist of cockles, and when the bird finds a difficulty in opening one of them. it Hies up in the arie and lets the molluse fall upon a rock or hard ground so as to break the shell. It also does great damage to the eross of game birels, and is considered by the cramelieeper quite as destructive as the ('imion (rom. The nest is a solicl structure. often built in cliffis, of the usual ('orvine trye, composed of twigs and branches, coarse roots, moss, wool, and a few feathers. There are three to six eggs in a clutch, of a green or greenish blue, generally clouded with brown spots and motflings and overlaid with linger mottlings of greenish-brown (see British Bird Egg ('abinet, drawer 6).

\section{Case 103.}

\section{RAVEN (Corvus corax).}

A resident species, local and diminishing in numbers. A few pairs are still found in the Northern Counties, but it is only in the milder parts of the north and west that the Raven occurs regularly, where it breeds in the eliffs of the high fells and on crag ledges of unfrequented dales.

Although exceedingly rare in Lancashire, it may be still seen on some of the wilder hills in the north of the Comnty, and there are few of the hill districts without some rock crag which takes its name from the hirk (Mitchell, " Birds of Lancashire." p. 83). In (heshire, Ravens were plentiful in the 15th century. and formerly frepuented the marshes of the Dee Estmary. A pair nestert on IIilbre Island in 1857 (Coward. "Birds of Cheshire," p. 102).

The nest is large and bulky and the same nest may be occupied

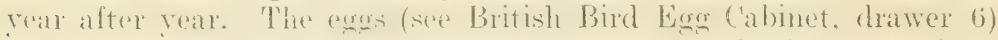
are laid rarly in the yeatr and do not ereatly exceed in size those of the Camion Crow: They are three to six in number, and have a ground colom of blush or areysh-green. thickly blotehed and overlated with. brown. 


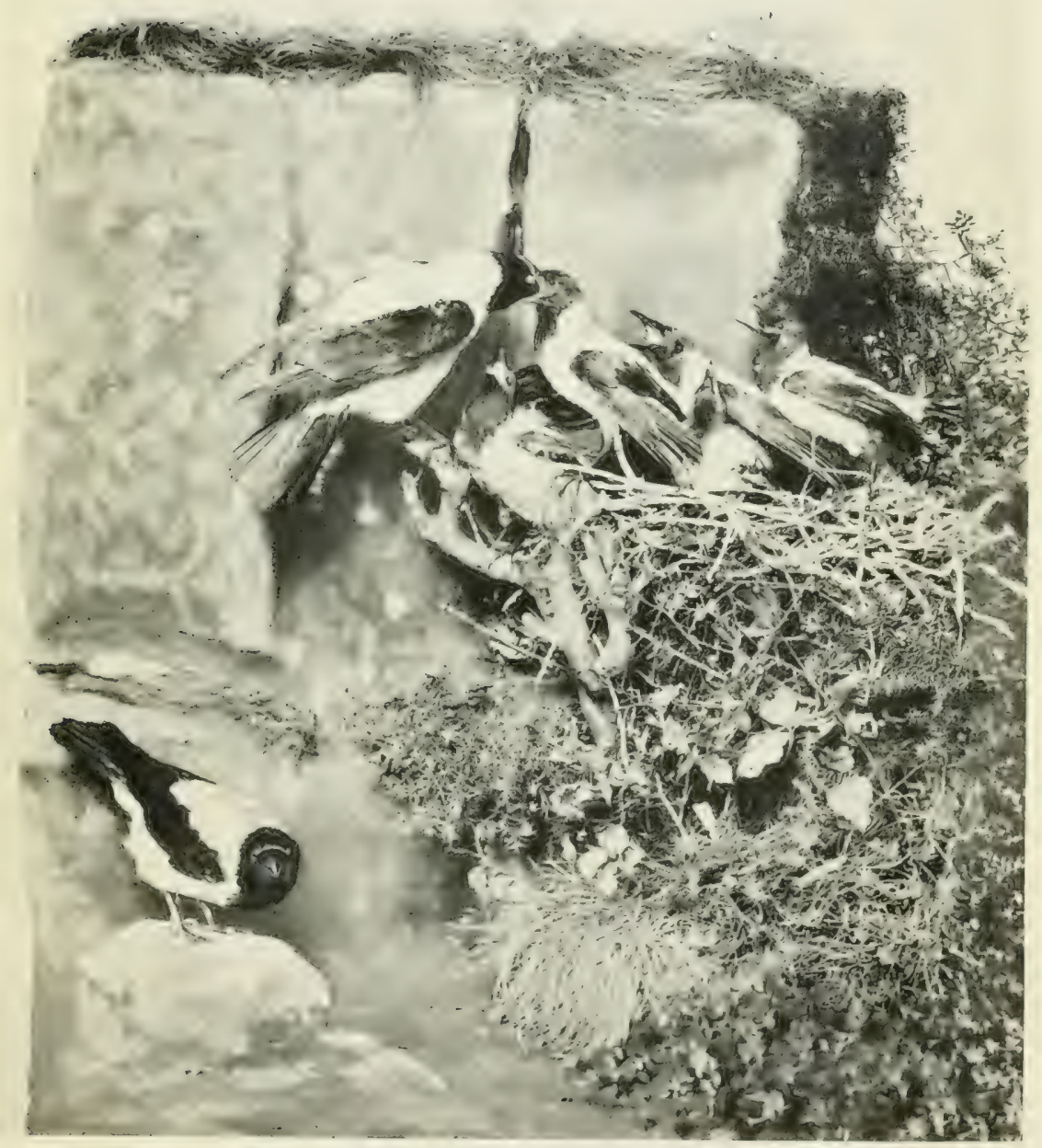

Hooned or Grey Crow Group.

Case 102. 




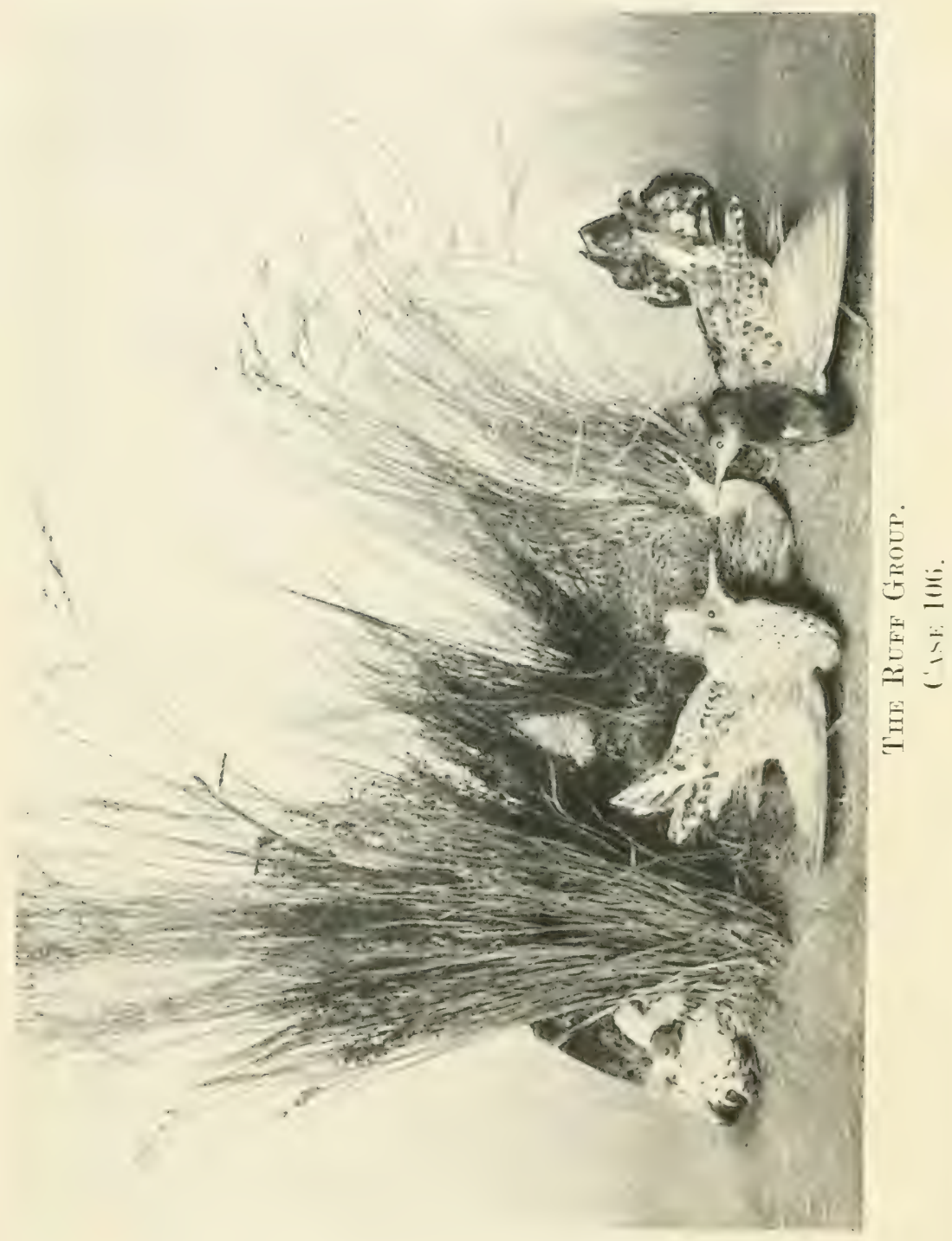




\section{Case 104.}

\section{CHOUGH (Pyrrhocorax graculus).}

Local name: Red legged Crow.

The C'hough, or Red-leogred Crow as it is sometimes called, is resident among sea-cliffs in Ireland, the west of Scotland. Wales. Cornwall, Devon and Dorsetshire, but there are no suitable places nearer to Liverponl than Anglesea and the Isle of IIan. It is of sedentary habits and rarely wanders far inland. The nest is unenerally placed in holes in cliffs or in cares. It is made of sticks and stems of heather and is lined with wool and hair. The eggs are three to six in number and are creamy white in colour, with greatly varving grey underlying marks and brown spots (see British Bird Egg Cabinet, drawer 5).

\section{Case 105.}

\section{JACKDAW (Corvus monedula).}

A resident generally distributed over the British Islands and abundant throughout Lancashire and the local area. It breerls in steeples and old beeches or oaks and is equally at home on cliffs. ruins. rabbit-warens or old trees in woorled distriets. Its nest ennsists of sticks, with smaller twigs and wool, or other soft materials forming the bed. Sometimes when built in hollow trees or in towers the accumulation of sticks is immense in order to raise the surface to within a convenient height from the entrance. instances being on record where the mass of sticks was 10 to 12 feet in height. The eggs, six in number, are bluish-green, marked with greyish or brownish spots (see British Bird Egg Cabinet, drawer 5).

\section{Case 106.}

\section{RUFF (Pavoncella pugnax).}

The Ruff is now chiefly a migrant, but in the fens and marshes of the eastern comnties it used to breed. It mostly visits our eastern and southern coasts and is sometimes foumd on inland waters. The males vary remarkably in plumare, and the breast shield and ruff, which the bind dons at the perion of the nesting seisom. is one of the most striking nuptial garments of any hired in the world. I tuft of long rough grass is invariably chosen for the nest. which is deep and always well concealed. The eggs, four in number, vary much in marlings. The ground is grenerally olive. buhlly spotted and blotehed with rufus-brown. In the group the artist portrays a very characteristic scene where several males are engager in deadly combat for possession of the female, who sits calmo he awatinge the issute of the fight. 


\title{
Case 107.
}

\author{
MAGPIE (Pica rustica). \\ Local names: Pye, Pyanet.
}

The Magpie is resident and common all the vear round in the woods of our local area: and throughout the British Islands, except in some parts of Scotland and of the south-east of England. In many districts it is much persecuted, and has been almost exterminated on account of the damage it dues to egges and young of game birds, although it is verv useful in destroying quantities of harmful inserts and grubs. The nest is large, composenl of sticks, the base being cemented with mud or clay and generally placed high up in the fork of a tree. It is suggested that the loading of the hase is for the purpose of steadying the nest by adding to its weight. A screen of sticks to shield the sitting bird from attark, is erected over the nest. It nests from mid A pril to early Mar, and lars six to eight exgs of a greenish colour, with small purple and brown markings (see British Bird Egg Cabinet, drawer 5).

\section{Case 108.}

\section{JAY (Garrulus glandarius).}

The Jay is resident in most of the higher woodlands of our local area and of Britain generally, except the north of Scotland and northwest of Ireland. It was formerly more common, being persecuted in many localities on aceount of its egrestealing and fruit-eating propensities. It hops on the ground instead of walking like the rest of the crow family and frecpuents thickly-wooded districts, building its nest at a height of from eight to twenty feet from the ground on a branch or in a high bush. The nest is open at the top and made of short twigs with a lining of fine roots and grass. It builds in Ipril and early May, laying from four to seven eggs, which show considerable variation in their markings (sees British Bind Fogn ('alhinet, drawer 5).

\section{Case 109.}

COMIION STARLING (Stumus vulgaris).

Local names: Shepster, Stare.

The Common Starling is one of the commonest birds in our local areal and indeed of Europe. It eats fruit, hut is most useful in destroying immense gluantities of harmful gruhs and inserets, and thus proves to be a great friend of the farmer. It nests in chimmeys, trees and under eaves, at the end of April. The nest, a large untidy structure is composed of straw and gratss, sometines lined with wool or feathers.

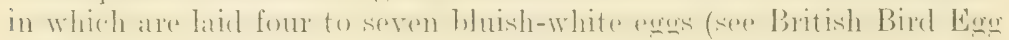
Cabinet, drawer 5). It is very prolific, rearing two broods in the

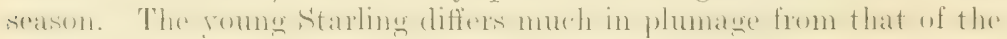
parents. A young specimen in its first plumage is seen in the group perched on top of the tree stump. 


\title{
Case 110.
}

\author{
BULLFINCH (Pyrhala europare). \\ Local names: 'Thick-bill, Nope.
}

Generally distributed in wooded districts throughout Great Britain

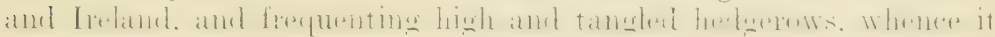
makes its way to orchards and gardens, where it has earned for itself a bad reputation by the regular way in which it proceeds to bite off the

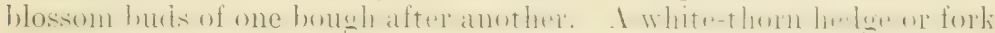

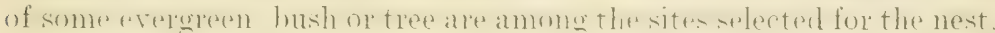
(The one here shown is built in a fir tree). The eggs, four or five in

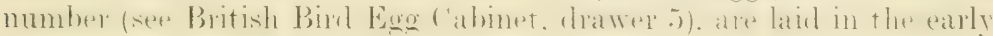
part of May.

\section{Case 111.}

\section{CHAFFINCH (Fringilla crebs).}

\section{Local names: Pink-Pink, Fleckie.}

A resident species and generally distributed throughout the cultirated and wooded portions of the British Islands. The food consists mostly of insects, varied, especially in winter, with seeds. The nest is usually placed in a fork of the lower branches of a tree (here shown in a rew trese or in a bush. and is remarkahle for its heatutiful (anstruetion. the whole of the materials being woven together so as to produce a shapely nest of almost miform consistency. It is remerally rovered with liehen or other highly deenrative matrital. and a mest has been

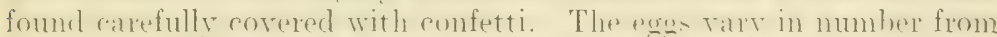

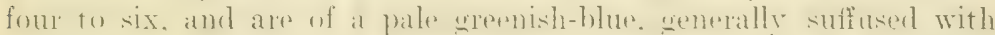
reddish-hrown and dark crimson markinge (see British Bird Egg (abinet. drawer t). The engs are lairl in April or Mar. and two broods are generally reared in the season.

\section{Case 112.}

\section{GREENFINCH (Ligurinus chloris).}

\section{Local name: Green Linnet.}

A resident and generally distributed species. frequenting cultivated and wooded districts. and in times of hard frost seen in assordation with sparrows starlings and robins around dwellings. Its food consists mostly of grain, seeds and insects. The nest a somewhat louse st rueture of coarse filorous roots, moss and wool. with a lining of hair and feat thers. is placed in hedges, shrubs and evergreens and even in trees (here shown in ash tree). The exgss. from four to six in number, laid in April or .Iay, are in colour white or pale French white, with blotches and spots at the larger end of reddish-hrown and purplish-grer (sere British Bird Ego Cabinet, drawer 4). Two broods are often reared in the season. 


\section{Case 113.}

\section{LESSER REDPOLL (Linota rufescens).}

\section{Local names: Grey Bob, Jitty.}

A resident, common in the lowlands of the northern counties. It feeds on the seeds of the thistle, groundsel, dandelion and other composite plants. The nest, which is usually built in a low tree or hush in some shelterel position, is rerv beautifully macte. It is formed nutwardly of a few fine twigr as a foundation. with dry grass stems, antermixed with moss and woul and lined with regetal)le down, the whole structure being very neat and compact. The eggs are very -mall and are four to six in number (see British Birl Eig Cabinet. drawer 4). Two broods are frequently reared in a season.

\section{Case 114.}

\section{TWITE (Linota favirostris).}

Local name: Noor Linnet.

A resident species frequenting heaths and moors, but during the winter months it leatres the higher gromed and mar be seen in thocks near the sea coast. The food consists mainly of seeds and in this, as in flight, general hahits and appearance, it much resembles the Linnet. The nest. made of twigs and ronts. lined with wool and feather's, is seually placed among heather or in a low bush, and often on the ground. Four to six egress of pale greenish blue, blotehed with reddish-brown (see British Bird Egg (allonet, drawer j) are laid towards the end of Whay. It is. however, easily distinguished from the Limnet, by its yellow beak.

\section{Case 115.}

\section{LINNE'T (Linota cannabina).}

Local names: Brown Linnet, Gorse Finch.

A resident and rommon species throughout the country, frequenting whin-covered moors, and gorse fields not far from the sea, but its numbers are affected by the professional bird-catchers. The food consists mainly of seeds. The nest is generally placed in gorse or low bushes, and the egges, fonr to six in mumber, are latid at the end of April or begimning of May, and are french white in colour, more or less tinged with green or blue and generally spotted or blotehed with reeldishbrown and purplish-red (see British Bird E⿺ra ('abinet. drawer 4). A second brood is often reared later in the season.

\section{Case 116.}

\section{GOLD-FINCH (Carduelis elegans).}

Generally distributed in the British J lands thoughout the summer months, but far less numerous than formerly, due to insuficient prosection from hird-ratehers. Instly migratory, leaving in october and 
returning in April, but in mild winter's many individuals remain. The neat compact nest of moss, fine twigs and roots, lined with down, feathers or hair, is usually formed about the middle of Mar, in the fork of a tree or more seldom in a hedge. The eggs, four to six in number, are greenish white, spotted and streaked with purplish-hrown (see British Bird Egg ('abinet, llawe: 1). Two hroods ale profluced in a year.

\section{Case 1ำ.}

\section{SISKIN (Carduclis spinus).}

Local name: Aberdevine.

Known principally in Englamel and Treland ats at winter visitor, but it breeds regularly in many parts of sontand. The nest is verediflicult. to find, being usually placed in the fort of a lenizontal branch of a pine tree, some distance from the stem, and a considerable height above

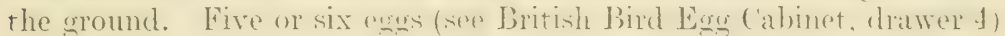

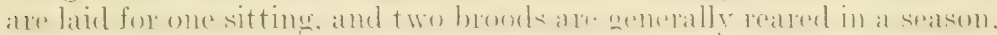
the first leaving the nest early in May.

\section{Case 118.}

\section{WOOD-LARK (Alauda arborea).}

A deciderlly local species. more plentiful in the southern counties of Fingland, and decreasing in numbers trwards the north. though it has been recorded as breeding in Sorotind. It is resident in Ireland in a few places only. Is its name implies it is a more wondland hird than the sky-lark, frequenting the neighbourhood of woods and plantations, and always affecting trees. Its nest is placed on the ground and skilfully concealed under a tuft of herbage or a small hush. It is composed of dry grass and fine rutlets, lined with finer grats's and a little hair, and is more finely put tougether than the nest of the sky-lark. The eges are four to five in number (sire British Bird Lige l'abinet. drawer (5), and have a white or redhish-white ground colour. numerously dotted with fine reddish-brown and grey spots.

\section{Case 119.}

\section{NIGH'TINGAlA (Daulias luscinia).}

This noted somgster is generally distributed. from the beginning of April till sepentembere orer the greater part of England. hut is rate in the northern and western wounties, and in thales. It has beren reconded in ('heshire, but is of douleful oremenere in Lancashire. Its farcourite resorts are small wookls and copplices in the neighbourhood of water and damp meadows, and, till the young are hatehed in Jume. its well known song can be heard at almost any hour of the dar or night. The 


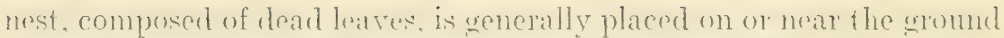

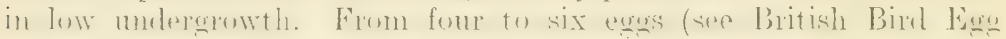

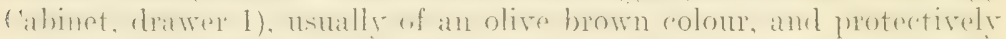

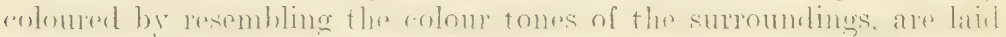
about the middle of May.

\section{Case 120.}

\section{CROSSBILL (Loxia curvirostris).}

This species is a somewhat rare resident in our islands. It has heen known to breed in numerous instances in England, but is more often met with in the northern counties of Scotland, and parts of Ireland. Its principal food is the seed of the pine and the larch, and the peculiar shape of the bill is admirably adapted for tearing open the cones. Four or five exgs (see British Bird Eorg ('abinet, drawer 5) are latid as early as February or March, and the mest is wsully situated in a pine tree some distance from the ground.

\section{Case 121.}

HAWFINCH (Coccothraustes vulgaris).

I farly numerous and increasing resident, but so great is its shrnesis. that it undoubtedly exists in many districts without revealing its presence. The food consists of the seeds of trees, the fleshy pulp of the most succulent fruits being rejected for the sake of the enclosed kernel. The love of the Hawfinch for green peas is notorious. The nest, generally placed in old hawthom, oak, apple or other fruit trees (here shown in the cherry), is built of twigs mixed with grey lichen, and lined with fine roots and hair. The four or five eggs (see British Bird Egg Cabinet, drawer 4) are laid at the end of April or early in May. One brood only is reared in the season. It may be noted that the first phumage of the rommg hirts is in this speries, quite different to either of its parents (see group), whereas in most finches the young bird in its first plumage resembles the female.

\section{Case 122.}

\section{GARDEN WARBLER (Sylvia hortensis).}

A common summer migrant arriving in the end of April, and often seen late in the autumn in gardens and orchards. It feeds on insects, peas, various fruits and berries. The nest is usually built in low trees and brambles (here shown in a sreamore treet) and is loosely comstructed of grass stems, with a well shajed immer eup of horsehair. The exges. four or fire in rumber, ase white, marked and blotehed with greenishbrown and riolet gley (see British Bird Egeg ('ahbinet. drawer 2). 


\section{Case 123.}

RED-BACKED SHRIKE (Lanius collurio).

A summer visitor arriving early in May, and irregularly distributed

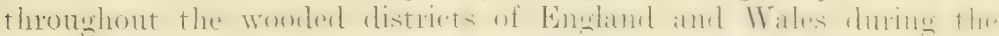

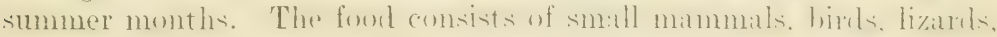

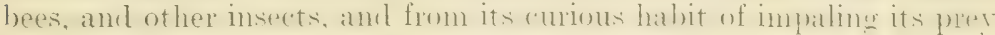
on thorns, this speries and its allies ate commonly known as " Butcher Birds" (note the larder of the pair here shown). It has also been suggested that by hanging up small mammals and birds in this way. flies and other insects are attracted by theil decompesition, and that therefore the so-called "larder" is used as a bait to attract insects upon which the Shrike feeds. The nest, made of moss and mots, lined with dry grasses, hair and wool, is ustally plareet in a thorn bush or thick hedge, five or six feet from the cround. Four to six exgs are laid which vary greatly in coloux and markings (see British Bird Eug Cabinet, drawer 4).

\section{Case 124.}

\section{REED BUNTING (Emberiza schoeniclus).}

Local names: Blackcap, Reed Sparrow.

Generally distributed and resident throughout the British Islands. frequenting the virinity of water and swamper plares when hordereel by osiers, reeds or rushes. The food consists of insects and theix larvæ, small freshwater animals, seeds and grain. The nest is usually placed amome tufte of rushes on or mear the gromel, and is made of

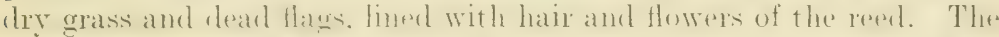
egors, four to six in number, anes pupplish-grey, holdly streaked with dark purplish-brown (see British Bird Equ (abinet. diawer j). Two and sometimes three broods are reared in a season.

\section{Case 125.}

\section{CORN BUNTING (Emberiza miliaria).}

I resident and lowally abundant species, esperially on the low dand: of the Mersey valley. and in corn fields and other arable land. reede and grain form the principal food. The loosely constructerl nest. ut drr grass and roots. lined with hair, is alwars plared on the erouml among growing corn, clover or grass, or under the shelter of a low bush. Four to five eggs of a dull purplish-white. blotehed and strealed with dark purplish-brown (see British Bird Eogr ('abinet. Hrawer j) are laid about the end of Nay. 


\section{Case 126.}

YELLOW BUNTING (Emberiza citrinella).

Lucal names: Yellow Hammer. Yellow Yoldring. Bessy Blakeling.

I common rexident. abumdant everwhere. frequenting farmyards and lawns in company with sparrows. The food consists mainly of insects, but in winter the seeds of many noxious weeds are eaten, thus doing a good service to the agriculturist. The nest, constructed of dry ganom and moss. lined with hair and finer material. is usually placed on or near the ground under tangled herbage, or in a low bush. The four or five eggs are of a purplish-white, streaked and spotted over

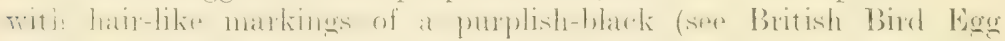
Cabinet, drawer 5). Two broods are produced in the year, the first set of eggs being laid in the middle of April.

\section{Case 127.}

(1) SNOW BUNTING (Plectrophenax nivalis).

Local names: Shore Lark, Mountain Bunting.

An annual winter visitant to our shores in considerable numbers. (See British Bird Egg Cabinet, drawer 5).

\section{(2) CIRL BUNTING (Emberiza cirlus).}

A very rare visitor locally. It is recorded to have bred at Formby. (Witchell, " Birds of Lancashire," El. 2. p. 79). (Nee British Bird Egro Cabinet, drawer 5).

\section{(3) ORTOLAN BUNTING (Emberiza hortulana).}

I mate of this species was killed near Manchester in Norember. 1827. and was figured he Selly (Mlitchell, "Bircts of Lancashire," Eid. 2. p. 79). (See British Bird Egg Cabinet, drawer 28).

\section{(4) LAPLAND BUNTING (Calcarius lapponicus).}

A very rare winter visitant, and only four times observed in Lancashire between 1834 and 1892. (Nitchell, "Birds of Laneashire, p. 73). (See British Bird Egg Cabinet, drawer 28).

\section{Case 128.}

\section{SKYLARK (Alauda arvensis).}

This well-known songster is widely distributed throughout the British Isles, and frepuents the vicinity of cultivated fields and grass lands. Its food consists of seeds, insects, and worms. The nest of dry grass is placed on the groume under tufts of grass, or in growing corn. The eggs are three to five in number, of a dull grey ground

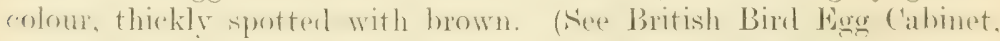
drawer 6). 'Two broods are usually produced in a season. 


\section{Case 129.}

\section{TREE-PIPIT' (Anthus trivialis).}

A summer visitor arriving early in April, frequenting enclosed and woody districts. The male hats a some not molike at camatry and he may be seen perched on the top of a hush ar tree. from whenere he rises singing inte the air. returning often to the hranch from whe he he started. The food comsists of insirets and small serets. The nest is placed on the ground near woods and plantations, and is formed of

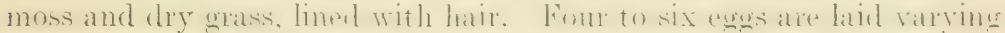

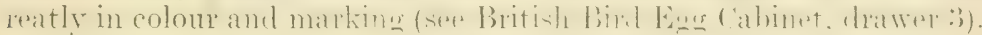

\section{Case 130.}

\section{MEADOW-PIPI'I (Anthus pratensis).}

Local name: 'Titlark.

Generally distributed throughout the British Islands both in the

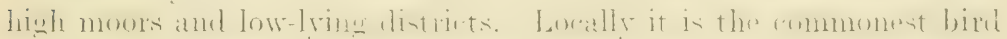
on the sand-hills. Its food consists of insects, worms, snails, and seeds. Large numbers migrate for the winter but many individuals remain

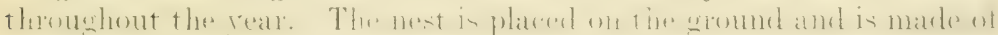
dry grass, lined with finer grass and hair. The eggs, numbering from

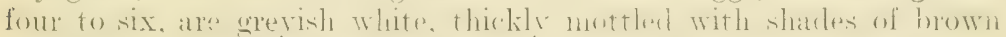

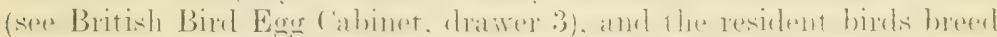
earlier than the migrants-usually two broods a vear.

\section{Case 131.}

\section{ROCK-PIPIT (Anthus obscurus).}

Frequents the more rocky portions of Great Britain, especially during the breeding season Wahner Istand is a well-known breeding haunt of this species. The sandy ("onsts of on locality are monited to) this rock-loring species. but its nest has heen foumd on the rorky islets of Ifilbre (Coward, "Birds of ('heshire," p. bilj). The fom consist. mainly of small marine shells, revestareans and inserets which may he found among seaweed. The nest is found in rock crevices on the grassy ledge of a cliff, or among (lumps of seapinkis. The expers are greenish grer, motted with olive brown, and number four or five

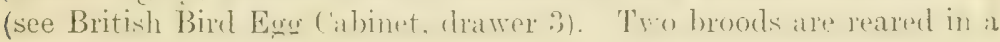
season.

\section{Case 132.}

\section{DARTFORD WARBLER (Melizophilus undatus).}

The Dartford Wanker is a resident in the south of kingland, and is rarely met with in the valler of the Thames and in some of the midland comnties. It doess not minate and in serere winters its numbers are liable to be greatly resluaerl. The nest, plated anomg the branches of 
the thickest furze and dilientt to find. is made of alats and furze shouts. lined with a little wool and moss. Four or five greenish-white eggs,

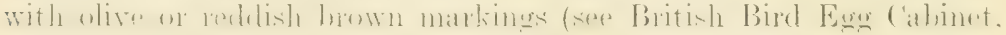
drawer 2) are laid in the end of April or the beginning of May. T'wo broods are reared in a season.

\section{Case 133.}

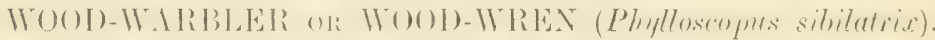
Local name: Fell Peggy.

One of the latest summer visitors, arriving in the south of England about the midelle of April. T'hough somewhat local, it is not uncommon in wooded districts. preferring old plantations of oak or beerh, where it may be seen searching for inserts among the higher branches. Its domed nest is always placed on the gromel among herbagre, and is invariably lined with fine grass and hair, never with feathers. Five to seven white egoss, thickly spotted with purplish-brown and grey (see British Bird Wge ('abinet, drawer 2), are laid about the middle of May.

\section{Case 134.}

\section{YELLOW WAGTAL (Motacilla raii).}

\section{Local names: Yellow Hand-Stir, Seedfore.}

A not uncommon summer visitor, arriving early in April and diparting in september. It is arenerally distributed during the breeding season throughout England, the south of Scotland and in parts of Ireland. The nest, of moss and dry grass, lined with feathers, hair and fine roots, is placed upon the ground and well concealed among rank yrasis and herhage. Fum to six mevish-white erges. mottled with yellowish brown (see British Bird Egg Cabinet, drawer 3), are laid towards the end of Mar. Two broods are sometimes reared in the season.

\section{Case 135.}

GREY WAGTAIL (Motacilla melanope).

Local name: Rock Wagtail.

The Grey Wagtail is nowhere a very abundant species and is far more shy and lowal than the othere Iragtails. It frequents secoluded spots esperially the neighbourhood of rear; rocky or gravelly watercourses. The nest is generally close to a stream on some rugged part of the bank, and is made of fibrous roots, dry grass and moss, lined with wool and hati or feathers. The exgs are from five to six in number. french white, closely mottled, and suffused with a very pale brown or slive (see British Bind Fug ('abinet, drawer 3). Two hroods are rearest in a season, the first is usually fledged by the end of May, and the second in July. 


\section{Case 136.}

\section{MARSH TITMIOUSE (Parus palustris).}

I resident species, frepuenting low-lving land and swampr ground neal woods. Insects form its principal food, and in winter the seets and berries of various plants. The nest, mate of moss, wool and hatir, with a lining of down, is usually placed in a hole in some deraved trees st mmp) (here seen in stump of willow). Five to eight white exors, spotted with bright red (see British Bird Eugre cabinet, drawer 3), are laid from the end of April onwards.

\section{Case 137.}

\section{COAL TITMOUSE (Parus ater).}

I resident but somewhat locally distributed species, freduenting woods, plantations and shrubberies, particularly such as contain firs. Insects form the principal food but seeds are also eaten by them. The nest is placed in the crevice of a loosely-built wall, as here shown, or in a hole in a rotten stump, often excavated by the birl, near the sround. It is built of moss, mixed with wool and hail felted together. 'The eggs, from six to right in number, are white, spotted or speckled with bright red (see British Bird Egg Cabinet, drawer 3).

\section{Case 138.}

\section{GREA'T 'TITMIOUSE (Parus major).}

Local names: Ox-eye Tit, Sawsharper.

An abumdant resident frequenting wools, sardens or corclosed and sheltered districts generally. Inserts form its main food, supplemented in antumn and winter with a variety of hart seeds. The nest, consisting of a foundation of moss, with a thick felted layer of short hairs, is usually built in a hole of a wall, as here shown, or in a tree, but many ndel sites, such as the insicle of a pump or pillar post box, are freduently chosen. The eggs, from six to twelve in number, are white, blotched, spotted or sperkled with light red (see British Bird Hog Cabinet, drawer 3).

\section{Case 139.}

\section{BLUE TITHOUSE (Parus comleus). Local names: Blue Nope, Blue Cap.}

A common resident, tame and familiar in winter, frequenting

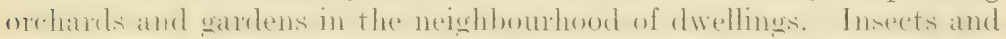

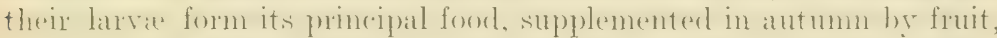

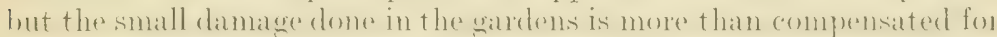
he the wholesile destrurtion of inseret pests. The mest is marle of moss, hair and feathers, and is generally placed in a hole in a tree, as here

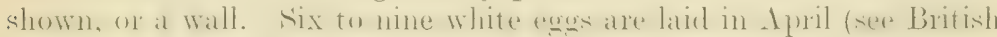
Bird Egg Cabinet, drawer 3). 


\section{Case 140.}

WREN (T'roglodytes parulus).

Local name: Kitty Wren.

I familiar resident. erenerally distributed and its number greatly increaserl be antumn inmingation. Its atctive. featress wass and loud mhereful song have endeared it to all. The heautifully constructed dome-shaped nest with the entrance at the side, is made of leaves, moss and grass, and ocrasionally lined with feathers. In situation it is reer varied, alwars well concealed in dense tangled regetation or in at hole in a tree trunk (as here shown). The exgers, from six to nine in

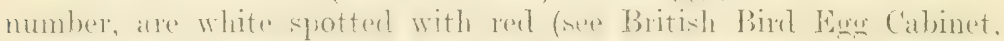
drawer 3). The nesting season begins early, and two broods are produced in the season.

\section{Case 141.}

\section{GOLD-CRESTED WREN (Regulus cristatus).}

This resident species is the smallest of our British birds, and is gencrally distributed whereser plantations of larch and fir are to be foumd. "The food consists of inserets. and being a rery social bird they are frepuently obsenved seatrehing for food in the eompany of floctss of Tits and creepers. The nest is beatutifully comstructed moss and lichen feltud togethel: with wonl and spiders" wehs and lined with feathers. It is generally placed beneath the extremity of a branch of some evergreen tree, such as fir, yew (as here shown), or cedar. Five to ten eggs of a pale bufi, minutely freckled with yellowish brown (see British Bird Egg Cabinet, drawer 2), are laid early in the season.

\section{Case 142.}

\section{LONG-TAILED TITHOUSE (Acredula caudata).} Local name: Bottle Tit.

The resident form of this sivecies is generally distributed throughout the British Islands. Its food consists of insects and their larve. The nest is usually placed in a bush such as a holly or ugrse bush (as here shown), but aceasionally in the lichen-eoremed hanches of a tree. It is oval in shape, formed of moss and wool, and felted together by spiders' webs. ancousted with lichens and lined with feathers. The entrance is placed in the upper part of the side. Seven to ten eggs, white in colour with indistinet molspots (see British Bird Eoge ('abinet. drawer 3), are laid in the latter half of April.

\section{Case 143.}

\section{SPOTTED FLY-CATCHER (Muscicapa grisola).}

A common smmmer visitor, appearing about the first week in May: genorally distributed throughout the British Islands. Its food consists 
principally of insects, which it captures on the wing. The nest. usually placed among creepers or trellis-work, or in a hole in a wall or tree (ahere shown), is mate of moss, lichen and strips of hark, lined with wool. hair and feathers. The egess, rarving in number from four to six, arm pale greenish-white, spotted and hloteherl with a deep listy hue (sope British Bird Egrge (abinet. drawer t). 'Two broods are often laid in a? season.

\section{Case 144.}

\section{TREE SPARROW (Passer montanus).}

The Tree Sparrow is a much rarer bird than the House Sparrow, and its distribution is more local. It is never seen in towns. but it may approach villages, where it associates with the house sparrow. It frequents old trees more or less remote from houses and is a very aretire. bird with rapiel flisht. Its foed is similar to that of the House sparrew. but consists more of small seeds than grain. The Tree Sparrow is rather a late hreeter and is excendingly partial to building in pollaw willows. The nest is loosely put togetherd. and is made of dery grass. straw and rootlets. The egos. from four to six in number, vary (onsiderahly in colour in different clutches (spe British Bird Eige (abinet. drawer 4), and two, sometimes three, broods are reared in a season.

\section{Case 145.}

\section{NUTHATCH (Sitta cresia).}

Local name: Kitty Wren.

A common resident in the southern and central districts of England. and in parts of Wales, but rare towards the north, only seen as a straggler in scotland, and unknown in Ireland. It feeds on insects. acorns and hard seeds. It is extremely partial to hazel nuts, which it werlges in some crevice and breaks by repeated blows from its strong bill, hence its name Nuthatch (i.e., Nuthack). The nest, of dry leares and bark, is built in a hole of a tree or other cavity, the entrance being reduced to a small aperture with chay. Five to six white extses, blotched with reddish-brown (see British Bird Eggg ('alsinet, drawer 3) are laid about the end of April.

\section{Case 146.}

\section{HOUSE SPARROW (Passer domesticus).}

('ommonly foumd throughout the British Islimels, attacherl to the habitation of man, appearing and raphilly increacing wherever the land is brought under cultivation. It is not particular as to site for its nest, wheh is plared in any suitable situation on buildinesor trees in their vicinity. When in trees it constructs a parge domed nest (as here shown) with an entrance in the side. It 
frepuently takes possession of the nests of the House and Sand Martin. driving away the jightful occupants. Four to six eges (see British Binl Eger (abinet, drawer t) are laid, amel, two, often three. hroods are reared during the season.

\section{Case 147.}

\section{I.ESSER SPOTTED) TOODPE(KER (Dendrocopus minor).}

A resident species, much more rarely seen than the Great Spotted Woodpecker. owing to its small size and partiality for high trees, but it is fairly common in many parts, especially in the southern half of England. 'The food consists almost entirely of timber-haunting insects. The nest-hole is usually made in the branches of tall trees. but sometimes at more moderate clevations, or in pollard willows and hombeams. Six or seven white egres (see British Bind Forg ('abinet, drawer 6) ares laid at the bottom on the bare wood, about the middle of May.

\section{Case 148.}

\section{WRYNECK (Iynx torquilla).}

Local names: Long-tongue, Cuckoo's Mate or Cuckoo's Leader.

This spring visitor, formerly numerous but now somewhat rare, arrives in Fngland towards the encl of Mareh or begimning of April. It is rarely met with in seotland. except during the autumm migration. and only accidental stragglers are known in Ireland. It frequents orchards and open parks rather than forest districts. It foeds mainly on insects, especially ants and their larva. 'The common name "Wrvned " is derived from its singular habit of twisting and stretching its neck. About the middle of May, convenient holes in hollow trees are used in which to deposit the eggs, white in colour, and from six to ten in number (see British Bird Egor ('ahimet. dramer fi).

\section{Case 149.}

\section{TREE-CREEPER (Certhia famitiaris).}

A resident species generally distributed throughout the British Islands, hut locally it is hecoming ratere than formerly. Its long emered claws and stiff-pointed tail feathers enable it to acrend the trumls and branches of trees with ease and rapidity as it searches for the spiders and other insects on which it feeds. The nest is made of roots, grass and moss, lined with wool, feathers, etc., and it is usually concealed uncler partially detacheal bark or in a reft in the bole of a tree. but

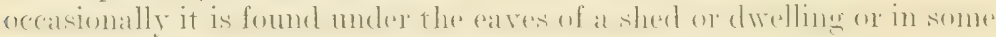
similar situation. Six to nind white regs. spotted with light red and

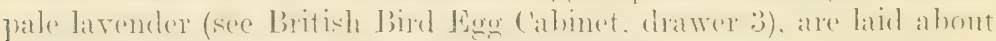
the end of April and two broods are reared in a season. 


\section{Case 150.}

(iREATER SPOTTED WOODPE(KER (Iendrocopus major).

A sparsely distributed resident. chiefty freguenting our fir woods Though it is generally distributed over Great Britain, but few examples have been recorded from Ireland. It is usually found in the highest branches of trees. feeting on insects and their larrar, as well as on berries and nuts, but owing to its retiring nature and colour protection it frequently escapes observation. In April, a circular hole is hewn by the birds in the trunk or branch of some tree, a dead one by preference, and within the stem a chamber is excavated for the reception of the eggrs. These are white (see British Bird Egg (ahinet, drawer 6). five to seven in number. and are deposited in the bare wood about the middle of May.

\section{Case 151.}

GREEN WOODPECKER (Gecinus viridis):

Local names: Heyhough or Yaffle.

The largest of the British woodpeckers, resident, and in England and Wales not uncommon in thick woods where it nests, but scarce elsewhere. It is almost unknown in Scotland and Ireland. Its insect fond is mostly taken off the tree stems, but it feeds ocrasionally on the ground, being especially partial to ants and their pupe. Early in A pril a circular hole is chiselled in the trunk or branch of a tree. usually decayed, and a nesting chamber is excavated in the heart of the stem. The eggs are glossr white and from five to seven in number (see British Bird Egg Cabinet, drawer 6).

\section{Case 152.}

\section{HOUSE-MARTIN (Chelidon urbica).}

This summer visitor is generally distributed throughout the British Islands, usually arriving about the middle of April, and departing in September or October, though consideralyle numbers are to be seen even later in the rear. The nest is made of mul, shaped like the half of a cup or basin, lined with fine straw and feathers, and entered by a hole in the rim. It is usually attached to the walls of houses uncler the eaves (as here shown), or it may be otherwise attached to some rock or other vertical surface, but alwars under some projection so as to be protected from the weather. The same nest is occupied year after vear -.- broken parts heing renovated. Four or five white egress (see British Bird Fggr (abinet, drawer t) are laid, and two, or even three, broods are reared in a season. 


\section{Case 153.}

\section{SWALLOW (Hirundo rustica).}

This well-known summer visitor arrives in the South of England early in April and is generally distributed throughout the British Islands till September or October. The nest of mud, open above and lined with dry grass and feathers, is usually built on the rafters of a barn or out-house. The eggs, from five to six in number, are white,

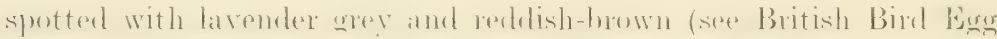
Cabinet, drawer 4). Two broods are reared in a season, the first,

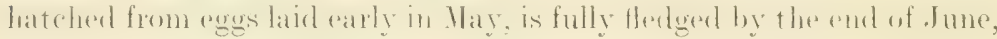
and the second by September. The young birds which are shown in the upper rafters under the tiles in the case, are part of the first brood

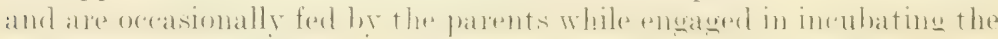
second set of eggs.

\section{Case 154.}

\section{SAND-MIARTIN (Cotile riparia).}

One of our earliest spring visitors, arriving towards the end of Inarch and departing by the end of september. It abounds wherever suitable nesting sites occur, i.e., the steep banks of rivers or lakes, sand-pits, gravel quarries or railway cuttings. In such situations tumnels varying from eighteen inches to six feet in length are loreed by the birds, the nest, of dried grass. lined with feathers, being placed in an enlarged rhamber at the enct. Four to six white exgs (see British Bird Eugg ('abinet, drawer t) are laid in the middle of Iay, and two broxks are usually reared in a season.

\section{Case 155.}

\section{SWIFT (Cypselus apus).}

The Swift arrives in the British Islands towards the end of April and remains till the end of Lugust. When the majority depart southwards to their winter quarter's. though individuals sometimes remain till much later in the real. The Hight of the hird is very rapid, and the foorl. consisting entirely of inserts, is taken on the wing. It is interesting to note that all four toes are directed forward, forming a four-tined salaple. They differ in this respeet to the Martin and Swallow. The nest is placed under the eaves of buildings, in crevices of eliffs, and, when available, in the crannies of the walls of old ruins (as here shown). The nest is a somewhat flimsy structure of straws, cobwebs,

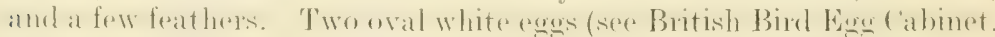
drawer 6) are laid in the end of May or early in June, and incubation lasts for eighteen days. Only one brood, as a rule, is produced in a season. 



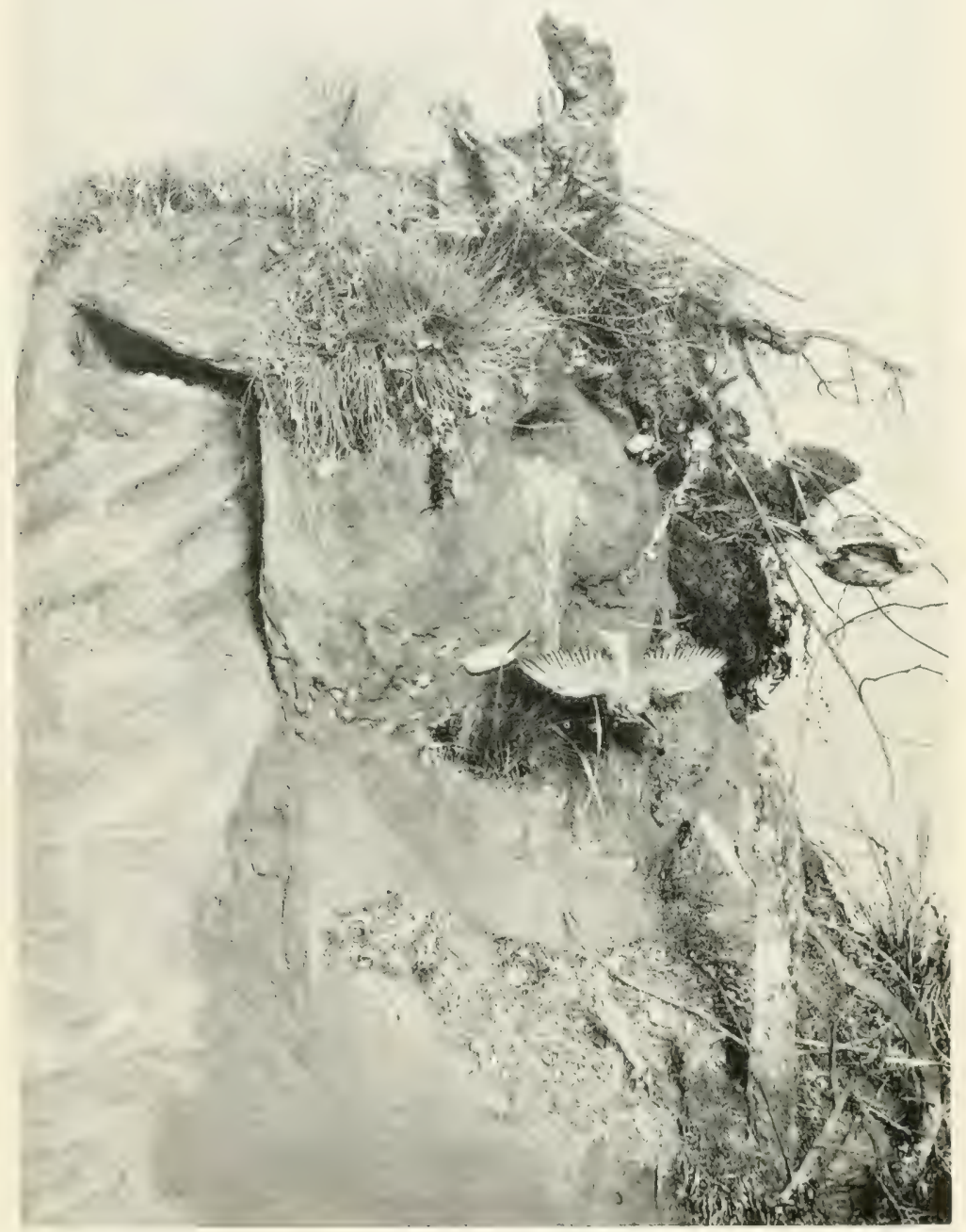

The Kungasher Group.

CAST $15 \%$. 



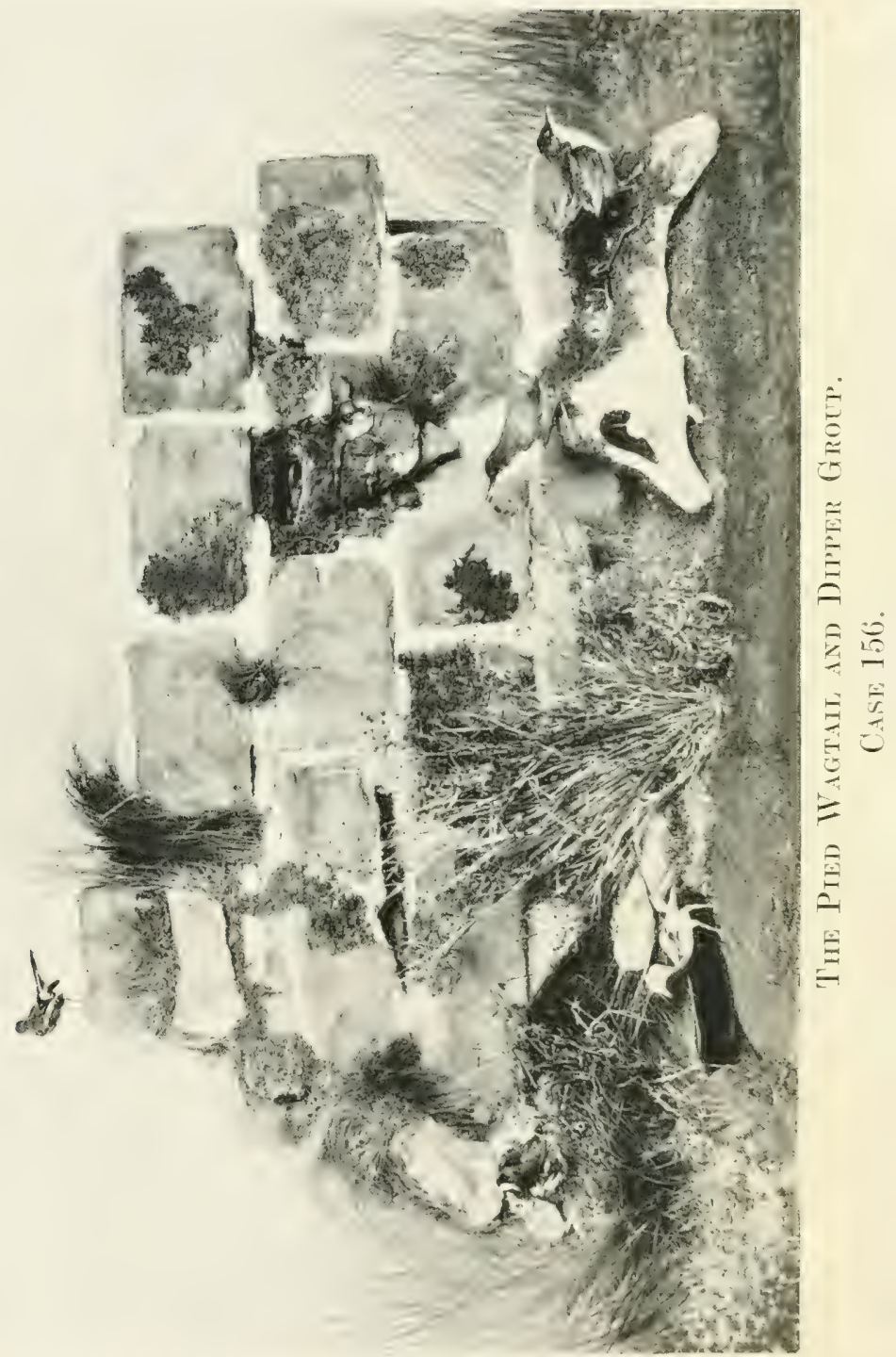




\section{Case 156.}

\section{DIPPER (Cinclus aquaticus).}

Local names: Bessy Ducker or Dowker, Water Ouzel.

A resident species found throughout the British Islands, wherever there are hills and rapid streams. It not only swims and dives with equal farcility but may be seen walking along the bottom, searching for the water insects on which it feeds. The nest, always placed close to the water's edge, is made of moss and leaves, and is oval in form with an entrance at the side. Four to six white exges (ree British Bird Egeg Cabinet, drawer 2) are laid early in the year, and sometimes three broods are reared in the season.

\section{PIED WAGTALL (Motacilla lugubris). Local name: Water Wagtail.}

This is a common and generally distributed species throughout the British Istands, espectially in the hreeding seasene. but a partial miglation takes place in autmm and winter. Flies and ayuatio insects form its principal food. The nest, made of moss, dried grass and fibrous ronts, lined with hair and feathers, is usually placed in a cleft in a bank or some hole in a wall or rotten tree. Four to six eggs, spotted and streaked with ash brown (see British Bird Egg Cabinet, drawer 3), are laid towards the end of April. Two broods are frecquently reared in a season.

\section{Case 157.}

\section{KINGFISHER (Alcedo ispida).}

A resident species. common about streams and lakes and on many parts of the coast of England, but less common in Feotland and Ireland. Its food consists of small fish, crustacea and insects. The fish are seized by a sudden plunge from a convenient perch above the water. The nesting place, which is a hole in the bank, is excavated upwards, to prevent flooding, for two or three feet, and terminating in a chamber. No nest is constructed, but on the floor, especially in old nesting places, scales and fish bones are often found, which have been cast up by the voung of previous brouds. The egos, from six to nine in number, are rounded, white and highly glossy (see British Bird Egg ('abinet, drawer 6 ). In the group exhibited part of the bank has been removed to show the internal construction of the burrow, with the eggs lying in the enlarged end.

\section{Case 158.}

\section{BEARDED TIT or REEDLING (Panurus biamicus).}

This resident species is now almost confined to the Norfolk Broads, the draining of the reedy fens and meres having destroyed many of its 
former breeding grounds in the eastern and southern counties of England. Its principal food consists of the seeds of the reed, but, in summer, numbers of small shell-bearing molluses are also eaten. The nest, placed near the water among sedere and weeds, is composed of dry leaves of aquatic plants and lined with the flowers of the reed. The eggs, from five to seven in number, are white with short wavy lines and markings of purplish-brown (see British Bird Ligg (ahinet, drawer 3). Two broods are produced in a season.

\section{REED WARBLER (Acrocephalus streperus).}

This summer visitor arrives in England towards the end of April and remains till September. It is not uncommon by the margins of our meres and osier thickets. The nest is generally suspended on reeds, or on the branches of willows and alders, which are woven into the sides. It is compactly built of fine dry grass, lined with flowering grasses, and is sometimes situated several feet above the surface of the water, Four or tive greenish-white eggis, clouderd and blotched with dart olive and ash (see British Bird Egg ('abinet, drawer 2) are laid towards the end of Mar. The ruckoo frequently places its egors in the nest of this species.

\section{Cases 159-161.}

\section{CUCKOO (Cuculus canorus).}

This well-known visitor is generally distributed during the summer months, arriving in the south of England about the first week in April. and remaining till dugust, or sometimes later. The food consists of insects and their larva, especially hairy caterpillars. No nest is built and the female cuckoo lays her egg on the ground, conveying it in her bill to the nest of a foster parent:-Hedge Sparrow, Wagtail, Sedge Warbler, Reed Warbler, Meadow Pipit (as here shown) and others. Soon after the young cuckoo is hatched, it ejects the other nestlings. Four to six eggs are laid in a season, and the eggs laid by different individuals vary greatly in colour. sometimes resembling those of the foster-parent (see British Bird Egg Cabinet, drawer 7).

Case 159.-The male bird is being mobbed by Headow Pipits (mobbing by smaller birds is common, probably because the Cuckoo is mistaken for a bird of prey). Both in size and colouration there is considerable resemblance between Sparrow Hawks and Cuckoos.

Case 160.-The female is seen depositing her egg in the Meadow Pipit's nest. It is suggested that the egg is laid on the ground, and carried in the beak to the nest as seen in the group, the beak being specially adapted 


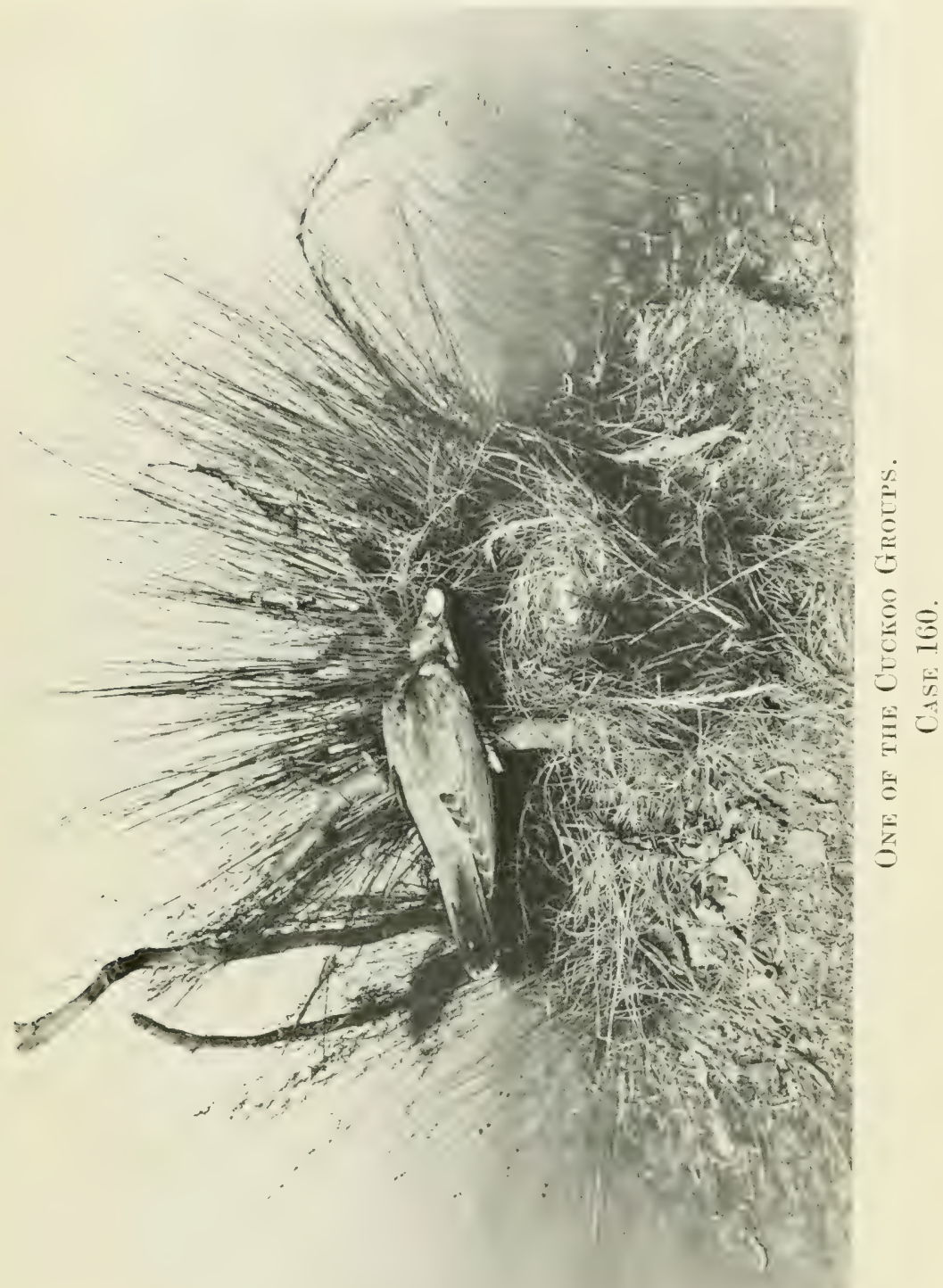



to hold the egg firmly, and yet without risk of damaging the tender shell. On the other hand other observers state that the egg is conveyed to the nest by the claws. It is interesting to note that the egg may be a good match in colour, with those of the foster parents. This may have been brought about by natural selection, as probably each individual cuckoo always chooses the nest of the same species for all her eggs.

Case 161. - The young ('nchoo is here seen occupying the nest of (a) the Hedge Sparrow, and $(b)$ the Wagtail. In both instances the foster-mothers are shown conveying food to the usurper.

\section{Case 162.}

\section{SEDGE-WARBLER (Acrocephalus phragmitis).} Local name: Water Nanny.

A common summer visitor. generally distributed over the British Islands from the latter half of April till the end of September. It frequents meres and reedy swamps. and the nest is generally placed in a low hush or among rank herhage by the sicle of some stream or ditch. It is composed of moss and coarse grass, and the inside is deep and thickly lined with hair. The exess, four to six in number, are of a pale rellowish-brown. generally suffused or sometimes slightly mottled with darker brown, and not imfrecquently streaked with hair-like lines of hlack (see British Bird Eign ('abinet. dratwer 2). They are generally laid towards the end of May and hatched in June.

\section{Case 163.}

BLACKCAP (Sylvia atricapilla).

A common summer immigrant, arriving about the midalle of April. and departing southward in Septrmber. a few hirels occasionally staying thoughout the rear. It frequents wouks. thick hedges, orchards and gardens. Its song is frepuently mistaken for the Nightingale. The ut st. built of dry grasses and lined with horsehand is usually fixed in a bush from two to five feet from the ground. The eggs, five to six in mumber, differ much in colour, and are usually vellowish-brown blotched with darker brown, but sometimes both ground colour and markings are of a redrlish hue (see British Bird liger Cabinet, drawer 2). The egos are laid first about the midrlle of Mar, and two broods are reared in a season. 


\section{Case 164.}

\section{LESSER WHI'ETHROA' (Sylvia curnca).}

\section{Local name: Hazel Linnet.}

A common summer immigrant, arriving about the middle of April and remaining as late as the begimming of octolser. It frepuents ligh and thick hedges and shrubheries, and is orasionally sern in lofty trees, but is seldom found in large woods. Its food is mainly the various stages of insecets, and when these alle salees fruit and herries. The mest is frepuently fomel in low hranehes. and is eompartly hoilt of strong stalles. lined with fibrous roots and horsehair. The exges. four to five in number, ale white. blotrlied and speckted over, mostly

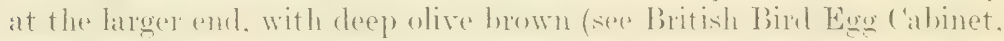
drawer 2).

\section{Case 165 .}

\section{GRASSHOPPER WARBLER (Locustella novia).}

Local name: Reeler.

A summer visitor arriving from the South about the middle of April, and departing in September. Being shy and restless in its

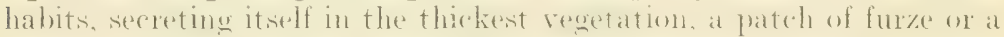
helge bottom, it is at all times dittionlt to ohtain a wimpere of this himel. The nest, built in May, is placed on tles wromed well hidelen amome thick herbage. It is ajplomeled by ome of more monse-like rums, and

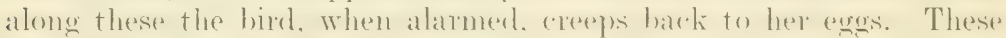
are from five to seven in number, pinkish-white, thickly zoned and

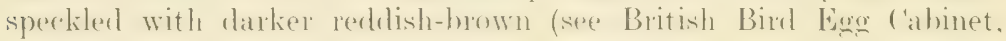
drawer 2).

\section{Case 166.}

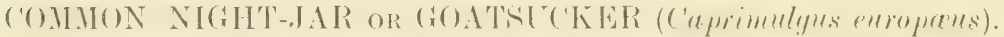
Loral names: Night-hawk. Fern (lwl, Evenine Jar. Jenny Nimner.

The Night-jar is a summer visitant to the woods and mosses of our local area, and to most parts of the United Kingdom, arriving in numbers fowards the end of May, and migrating again in september or somewhat later. It oceus over all Eurepe. The Night-jar, which flies in the twilicht when it utters a peculiar " jarring " or "churring " note. feeds rhiefly on insects. This hird makes no nest, laving its two egos (see British Bird Eger ('abinet, dlatwer (i) on the bare groumd in the besimning of Jume. A very chatracteristir habit of this species is here illustrated. When alarmed by the approach of strangers in the neighbourhood of the nest. the hird goes fluttering along as if womded. therehy entiong the strangers, not knowing this habit, to follow. The bird always leads away from the nest. 


\section{Case 167 .}

CHIFF-CHAFF (Phylloscopus rufus).

Local name: Peggy.

The Chiff-Chaff is a rather rare summer visitor to our local area, and is more numerous in some parts of Britain than in others. Its food consists of insects and gruhs. The ('hiff-('hati arrives in March. and migrates about Septemluer. It nests late in May or carly in June. and lays from five to seven aggs (see British Bird ligg ('abinet, drawer. 2) of two distinct trpes of colouration. It builds a domed nest like the Willow Wren, hut no moss is used for lining as in the nest of the latter. The Chiff-Chaff differs from the Willow Warbler and the Woul Warbler by its rounded wing. the second gnill being of the same length as the sixth; and also by its dark feet.

\section{Case 168.}

WILLOW WARBLER OR WILLOW WREN (Phyllescopm:s tiochith.'). Local names: Peggy Whitethroat, White Wren, White Robin.

The Willow Warbler is one of the commonest birds of the woods and orchards of our local area, as it is of most parts of Britain. It arrives in $A$ pril from its winter home in Africal and migrates again in Autumn. The Willow Warbler feeds on insects. It builds such a nest as is here shown. usually in May and lays from five to eight reddishspotted exges (see British Bird Equ (abinet, drawer 2). The Willow Warbler is chistinguished from the Wood Warbler (which it closely resembles). by its smaller size and duller colour: and also from the Chiff-('haff' by having a pointed wing (whose third and fourth quills are the longest) instead of a rounded one.

\section{Case 169.}

(1)MIION ROBIN or REDBREAST (Erithacus mbecula).

The Robin resides the year through in all parts of our local area : ranging also throughout the rest of Britain. In atutumn, numbers migrate from one part of the country to another only. while others cross to the continent, returning again in the spring to their usual haunts. The Rohin builds in April and May laving from five to eight egers which vary comsiderably both in egromed colour and markings (see British Bird Bigg (abinet, drawers 1 and 7 ). The location of the nest is very varied, and although a hole in a bank is the site generally adopted. it frequently uses disused tin cans (as here seen) as a shelter. The Cuckoo often deposits its egge in the Robin's nest. It is interesting to note that the plumage of the nestlings differ's from that of the parents. which it will fully resemble only after the first antumm moult, except in the tips of the middle wing coverts. which remain buff till the following spring. 


\section{Case 170.}

REDSTART (Ruticilla phonicurus).

Local name: Jenny Redtail.

An early spring immigrant, sparingly distributed. The Redstart frequents the skirts of forests, orchards and gardens and is partial to old walls and ruins overrun with ivy. The food consists of worms, insects, fruits and berries. The nest, loosely constructed, is formed of dry grass and fine roots, lined with hair and feathers, and is usually placed in some hole in a tree, wall or roof. The eggs, from five to seven and even eight, are pale greenish-blue (see British Bird Egg ('abinet, drawer 1). Two hroods are often produced in a season, the young of the first being fledged by the second week in June.

\section{Case 17 1.}

STONECHAT (Pratincola rubicola).

Local names: Stone Chack, Flick-tail.

This species is resident throughout the year, but is irregularly distributed, frequenting commons and furzy wastes. It closely resembles the Whinchat both in its nesting habits and number of eggrs, the nest heing placed on or near the ground in some furze bush, but it is built much earlier in the year, about the middle of $A$ pril, and the eggs are somewhat greener in colour (see British Bird Esg ('abinet, drawer 1). The nest is here shown in a gorse bush.

\section{Case 172.}

\section{WHINCHAT (Pratincola mbetra).}

I summer visitor, generally distributed over (ireat Britain from the middle of April to early in (ictoher. In Ireland it is limited to some of the southern counties. The food consists of insects, worms and berries. Its nest, constructed loosely of dry grass and moss, lined with hair, is made about the beginning of May, and is msually formed in some hollow in the ground well concealed by surrounding foliage. The egus are greenish-blue fantly zoned with rust colons, and are usually six in number (see British Bird Egg Cabinet. (lrawer 1). Two broods are sometimes reared in a season.

\section{Case 173.}

\section{HEDGE ACCENTOR (Accentor modularis).}

Local names: Hedge Sparrow, Hedge Dunny, Dunnock, Drker.

A resident, generally distributed over the British Islandis. It frequents woods, hedgerows, and gardens, and feeds indiscriminately on insects, worms and seeds, but not fruit. It is very nearly the first bird to build its nest, which is placed in an almost leatless hedge and 
is made of roots, moss and wool, lined with hair. Four to six eggs of a light greenish-blue, without spots (ser British Bird Equg ('ablinet. drawer 2), are laid early in 1 areh. I second or eren a third brood may be reared in a season.

\section{Case 174.}

GREATER WHITETHROAT (Sylvia cinerea). Local name: Peggy Whitethroat.

The Yettle-creeper. as this hird is also called. is one of our commonest summer visitors. It is generally distributed throughout the British Islands from the middle of April till the begimning of September. It frequents hedgerows and thickets overgrown with hrambles and nettles. The nest. a lightly constructed structure, of fine grass, with a lining of bents and horsehair. is almost invariably placed low down in straggling brambles or nettles. The egiss are greenish-white or stone colour. blotehed with violet grey and light hrown (see British Bird Eqg Calbinet. drawer 2).

\section{Case 175.}

\section{WHEATEAR (Saxicola xnanthe).}

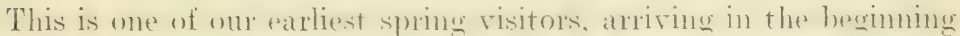
of Narch and leaving parly in ()etolser. It is generally, though locally. distributerl throughout the British Islands and frerquents the wilder parts of the country, such as open downs, heaths and barren hills. The white patch on the rump, so conspicuous when in Hight. is entirely hidden when the bird is at rest. The nest is loosely made of chry grass. lined with hair and feathers, and is variously placed in rabbit hurrows. crevices of stome walls and heaps of stomes. The erges are very pale blue, sometimes faintly spotted with purple (see British Bird Egg Cabinet, drawer 1), and vary from five to seven in number. Two broods are produced in a season.

\section{Case 176.}

\section{RING-OUZEL (Turdus torquatus).}

A spring visitor which arrives in the British Islands in Ipril, remains till september or Octrober when the majority move southwarks. but in mild seasons individuals have been observed as late as December. It is more abundant in the fells and more elevated districts. It feeds on moorland herries. slugs. worms and insects, and often visits gardens in search of fruit. The nest is plared in heather or on lerlgess of rock. often on the side of a stream, and resembles that of a Blackbird. The egges also resemble those of a Blackhird, but are usually more boldly marked, and are four and sometimes five in number (see British Bird Egg Cabinet, drawer 1). Two broods are produced in a season. 


\section{Case 177 .}

\section{BLACKBIRD (Turdus merula).}

A resident species commonly distributed thronghont the British Islands. Snails, worms and insects as well as fruit of all kinds constitute its food, and owing to its partiality for fruit, great numbers are annually destroyed in gardens and orchards. The nest, generally plareed in bushes and hedgerows is marte of moss. lined with dry grass. Four to six egas are latid, usually greenish-blue spotted with beddishbrown (see British Bird ligge ('abinet, drawer 1). Several hrowds are reared in a season.

\section{Case 178}

MISTLE-THRUSH (Turdus viscivorus).

A resident species known as the "Stormeock" from its habit of singing during the roughest weather, and found wenerally thromghout the British Islands. It feeds on fruits, worms, snails and insects, and is especially partial to the berries of the yew, holly, mistletoe, etc., from the last of which the trivial name is derived. The untidilyfinished nest is generally placed in the fork of a tree some clistance from the ground. Four to five exger are laid, sometimes as early as Fehruary. of which the erround colour is greenish or tawny white, blotehed with reddish-brown and lilare (see British Bird ligge ('abinet. (lrawer 1). Two broods are often reared in a season.

\section{Case 179.}

SONG-THRUSH (Turdus musicus).

The "Throstle" or "Mavis" is a common resident throughout the British Islands. The food consists of fruit, snails, worms and insects. The familiar nest, lined with mud, is senerally placed in a thick bush, and the first clutch of egos, from four to six in number. is laid early in March. Ther are greenish-blue, usually blotched with black or purplish-brown, but are sometimes unspotted (see British Bird Egg Cabinet, drawer 1). Two or three broods are reared in a season.

\section{Case 180.}

\section{BARN OWL (Strix flammea). \\ Local names: Howlet, White Owl.}

Probably the best known of all the British Owls, and resident throughout the rear. It inhabits churches, barns, deserted ruins and hollow trees. and the same haunts are frequented by the same pair or their oftspring for many rears in surcession. They feed on 


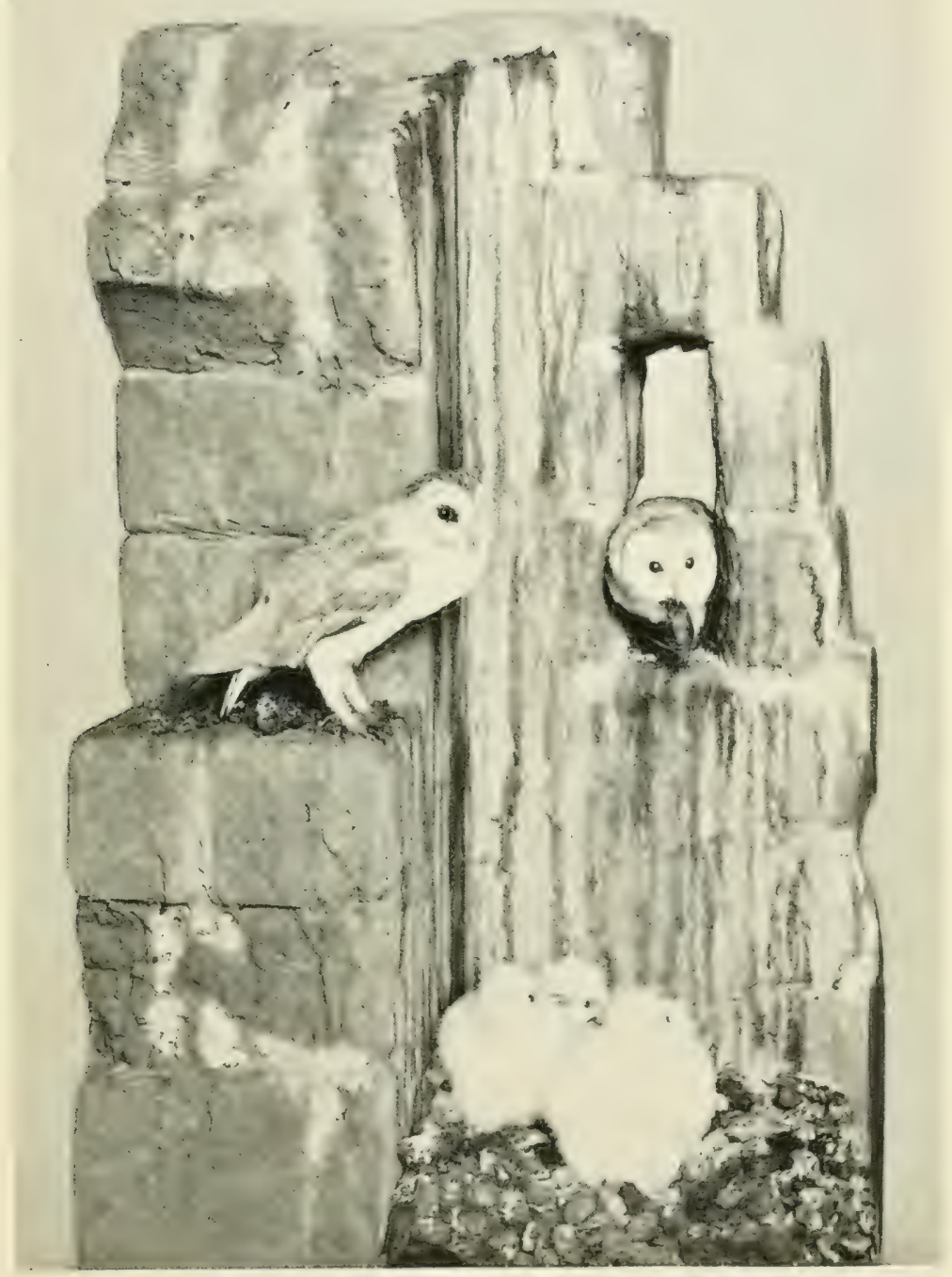

The Barn Owl Group.

CANE 180. 

rats, mice, shrews and small birds, and less commonly on insects, parts of all of which have been recognised at different times on eximmination of the pellets rejected thromen the mouth, which ale ax+merally to be found in abundance near any place of their resort. The Barn Owls undoubtedly render gomb service to the agriculturist he the destruction of remin. Two to six egus are commonly lairl. of a dull white in colouring (see British Bird Eogr ('abinet, drawer T).

\section{Case 181.}

\section{TAWNY OWL (Symium aluco).}

Local name: Wood-owl.

This species, also known as the Brown Owl, is fairly common throughout creat Britain, wherever wouls and rages suitable to it: habits alle found. It doess not appear to oreur in lreland. It is more. nocturnal than any other British ()wl, and feests rhefty on rats. mice. moles, and sometimes on small birds, insects, or surface-swimming fishes. The nesting sites vary mueh. the most usual being a hollow in the trunk of a trees, but oli nests of Pooks. ('rows and of hes bive are frequently used, while ruins, barns and disused chimneys are sometimes resorted to, and not infrequently the bare ground, under shelter of fir branches or roots. Three or four eggs, smooth, white and nearly pound in shape (see British Bird bigg ('ahinet. drawer 7 ). are laid sometimes as early as the end of February.

\section{Case 182.}

\section{LONG-EARED OWL (Asio otus).}

I resident species. generally distributed throughout the wooded distriets of treat britain and Ireland. and espectally partial to fir plantations. In Lancashire, it is more sparsely found than other British ()wls, hut is plentiful in some parts of the comnty. Witton Park. Blackhurn. is recorded as a nesting site ('oologist. 19101. p. 25y). Noctumal in habit, it feeds principally on small rats. mice and hirels. and occasionally beetles and other insects. The exgs. white, and from four to six in number (see British Birl Eug ('abinet, llawer 7), are usually laid rery early in the rear in an old squirrel's drey, or in the deserted nest of some large bird (as here shown). but recasionally they are laid on the ground, at the foot of a hollow tree.

\section{Case 183.}

\section{SPARROW-HAWK (Accipiter nisus).}

The Sparrow-Hawk is a our local area as of the British Inles generally, and ererrwhere across central Europe and Asia. It feeds on small hirds (ratching them 
unexpectedly in trees and hedges, and pursuing them even into woods), game nestlings, mice and rats. In llay the sparrow-hawk either builds a nest for itself, or appropriates a disused one, in a fairly high tree, in which it lays from three to four, or sometimes five, very variably marked exgs, usually pale bluish-white blotched with reddish-brown (see British Bird Eugre ('abinet, drawer ?). The male is always much smaller than the female.

\section{Case 184.}

\section{MERLIN (Falco cesalon).}

Local name: Stone Falcon.

The Merlin is a resident, but by no means common, in our local area, and as a breeding bird is more abundant in northern England and Seotland than in England or Ireland. It oreurs over all the mountain districts of northern Europe and Asia. It feeds chiefly on small birds such as larks, dunlins, etc., and often large moths, which it "flies down "in the manner of the larger falcons. The Merlin nests usually in a hollow scratched in the ground, sometimes on a rocky ledge and very rarely in a tree, laying in May from four to six eggs (see British Bind Egen (abinet, drawer s). The roung of the Merlin and spatrow-

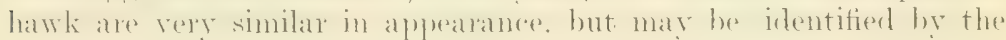
colour of the eyes, the iris of the Merlin being dark brown, while that of the Sparrow-hawk is yellow.

\section{Case 185 .}

COMION KESTREL (Falco timnunculus).

Local name: Windhover.

This hawk is common throughout our local area, as in all parts of the British Isles and Northern Europe. Its food consists largely of field mice, other small mammals, frogs and insects, and very occasionally of small birds and chickens. It is a most useful bird to the farmere and gardener. The Kestrel early in Apuil lays its rather variable egess (see British Bird kige (abinet, drawer s), three to seven in number, in at disused nest of a crow, pigeon, etr., in wooded districts, and also on the bare rock on shore cliffs.

\section{Case 186.}

\section{PEREGRINE FALCON (Falco peregrinus).}

The Peregrine Falcon is rather a rare resident among the high rocky fells of om local area. It freequents all the sea clifts and uplands of Fingland and Wales, and espertally of Scotland and Ireland, and throughout the northern and temperate parts of Europe and Asia. It has long been esteesmed the hest bird for the purposes of falconry. 
It feeds on all game, marine and other birds, often of large size : and also on hares and rabbits. It has been observed, through telescope. hunting ducks on the Dee. The Peregrine Faleon nests in April, in the same place rear after rear, in rock hollows on high inaccessible cliffs, laying from two to four very variable eggs (see British Bird Lgg (abinet, drawer s). It is interesting to note that the helpless young are not protectively coloured by resembling their surrounting. like the roung of so many other birds. but are conspicunonsly white. It is suggested that as the parents (of whom one is always in attemelance on the nest) are so formidably armed with beak and claw, the necessity for colour protection has disappeared, and that the conspicuns. whiteness serves as a signal to other birds and animals of the riskis they rum in attempting to prey upon them. There are many examples of such warning colouration in the animal kingdom.

\section{Case 187.}

\section{COMAON BUZZARD (Buteo vulgaris).}

A much persecuted resident, nesting now only in our lake listricts or where it receives least molestation from game-keepers. The food consists chiefly of young rabbits and hares, but reptiles and inserts are also eaten. The large nest, of sticks and dead heather, is built in a tree or placed on the ledge of a cliff. Three or four greyish-white eggs, blotched with reddish brown and lilac (see British Bird Egg Cabinet, drawer 9) are usually laid in April. Both birds participate in the incubation of the eggs.

(The birds in the group are in an immature stage of plumage.)

\section{Case 188.}

WHITE-TAHAED OR SEA E.AGLE (IIaliatus albicilla).

This species is principally observed in England as a migrant in autumm and winter, though it formerly heed on many parts of the coast in the Lake District and it still breeds in the western islands and North-west of scotland. The immature specimen (wing extended) in the group, was killed at Blundellsands in the winter of 1895 . The food consists of the smaller game, i.e., hares, young deer and ducks. and it also feeds largely on carrion. The nest is a huge structure of sticks, added to year by year until it attains an immense size. The site of the nest varies, usually on ledges of cliffis, often on a rock in the middle of a lake, sometimes in trees and rarely on the gromul. The two eggs are white or whitish-brown when nest stained (sep British Bird Egy Cabinet. drawer 9). They are smallen than the megs of the Golden Eagle and somewhat rounder in form. 


\section{OSPREY OR FISH HAWK (Pandion haliaëtus).}

Though formerly said to breed on the north coast of England and in the Lake District, the eyries of the species are confined to a few places in sootland. In antumn at considerable number oceur in various parts. especially estuaries of large rivers and inland lakes. The foort "onsists entirely of tish, and the spiky soles and powerful talons of the feet enable it to hold the fish secturely. The favourite brecting haunt is a forest, with water in the vicinity where fish abound. The large nest is placed in a tree or on some ruin near an inland lake. The eggs are very tinely marked. ground ablour white sometimes entirely hidhen by real in purple blotches which congregate at the larger end of the egg (see British Bird Egg Cabinet, drawer 9).

\section{Case 189}

\section{GOLDEN EAGLE (Aquila chrysatus).}

The proprietors of deer-forests now afford protection to this grand birel of prev. with the result that they have increased greatly during recent years. Its breeding places are confined to the Highlands of Scotland, the Hebrides and the north and west of Ireland, but in exreptionally severe winters it sometimes risits the soutl of scotland and very rarely, England. One was recorded near Furness Abbey in 1815) (Dunsford. "Birds of Walney"). It preys upon mountain hares. lambs and even voung rest deer, also grouse and ptamigan. The nest. built of sticks and dead heather, lined with coarse grass and bits of scoteh fir, is usually placed on some inacressible ledge on a cliff and occasionally in a tree. The greyish-white exgers, blotehed more or less with reddish-brown and lilac (see British Bird Egg (abinet, drawer ?), are laid early in April, and the young are on the wing early in August.

\section{Case 190.}

GANNE'T oR SOLAN GOOSE (Sula bassana).

This species is found throughout British water's during the autumn and winter months, when it may frequently be seen in liverpool Bay. In spring it repairs in rountless numbers to some isolated rock to breed. The most noted breeding onlonies are Lundy Island, Frassholme. off Pembrokeshire, Ailsal ('rag, off the Butt of Lewis. Boreray (St. Kilda), the Bass Rock, the Bull Rock, off' ('o. C'ork, and the Little Skellig. Fish. which are caught be plunging, often from a great height. form its foorl. (Bnly one exg, of a pale blue orerlaid with a challiy white coating (see British Bird Egge ('abinet, drawer 10). is laik in a nest malle of seaweed and grass The young, naked when hatched, soon become 



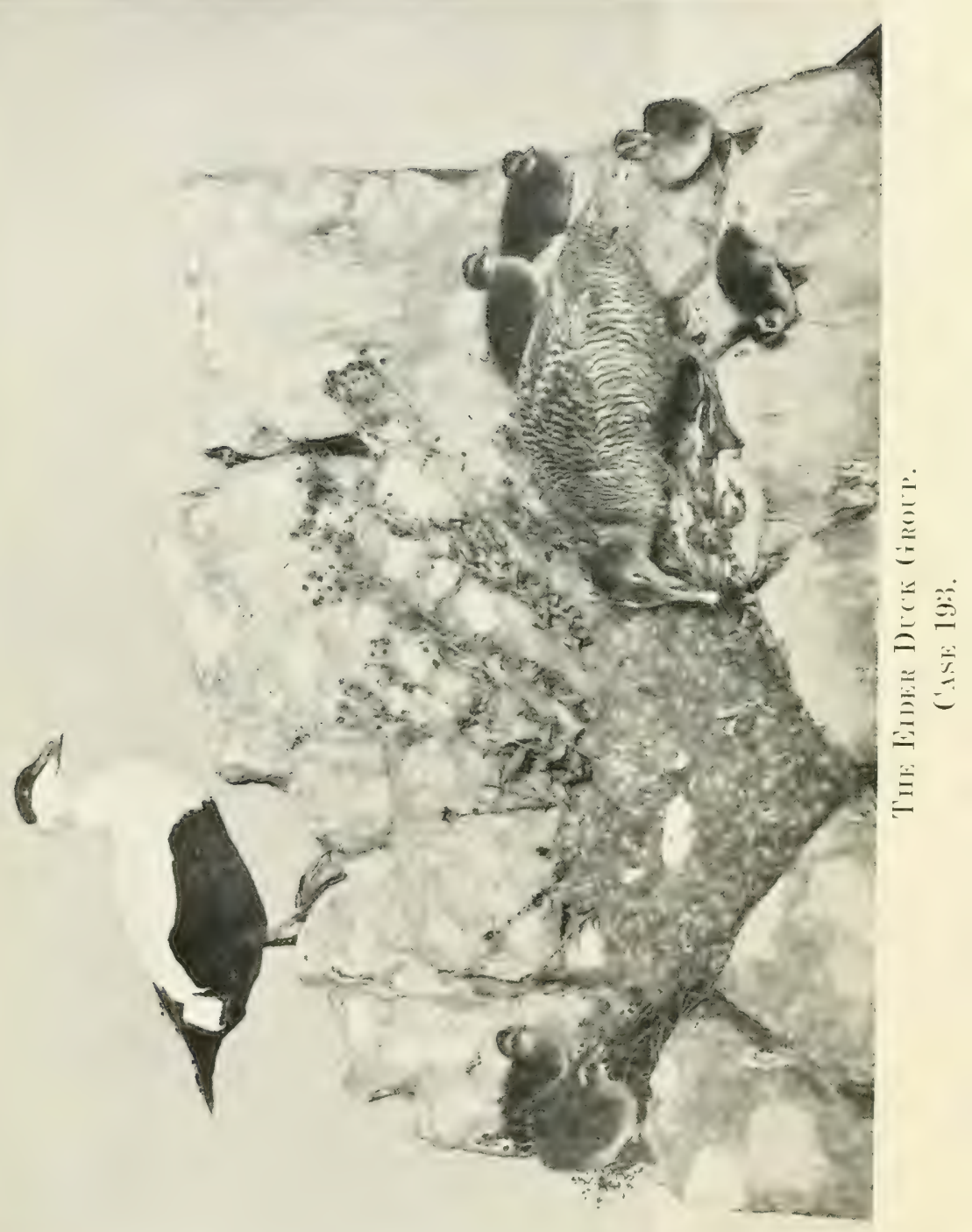


covered with white down, replaced in a few weeks with dark feathers tipped with white. There are four distinct changes of plumage, the mature plumage notfbeing assumed until the fifth year.

\section{Case 191.}

SHAG oR GREEN CORHORANT (Phalacrocorax graculus).

This species is also known as the Crested Cormorant, from the curved tuft-like crest, which is assumed in the early spring and shed in Mar. Though essentially marine and common along all the rugereel (o)asts of the British Islands it is not so (onmmon lowally owing to the lark of nesting sites. It is an expert diver and ferels principally on sea fishes. The nest, generally placed on a ledge of rock, is made of seaweed and other badly-smelling materials plastered together. From three to five eggs, with a pale blue undershell thickly encrusted with

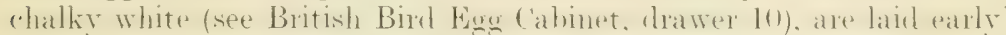
in Mar. 'The manmer in which the vomme are feet is remarkahle. The' balent birel, with its sullet filled with fish. bends over the voums. "pening its bill to the fullest extent. upon which the roung bird thrusts its hear and neck down the old bird's throat and extrarts the partiallydigested food.

\section{Case 192.}

\section{GREY IAG-GOOSE (Anser cinereus).}

The only species of wild goose nesting in the British Islands. Locally, it is seen in flocks during the spring and antumn migration resting on the sand-banks off the mouths of the Mersey and Dee. In Norecambe Bay and the Ribhle Estuary. where other waders have ceased to find suitable rendezvous in the reclaimed land, geese of several species annually muster to the number of many thousands (Mitchell, "Birds of Lancashire"). A pair of this species nested on the Formby Sands in 1904, hut their egess being taken the hirds left. The nest of reeds, dry heather, etc. is zenerally placed among coarse grass, rushes or heather. Four to seven yellowish white eggs (see British Bird Egg ('abinet, drawer 12) are laid, surrounded by down, from the breast of the female. The males take no part in the incubation.

\section{Case 193.}

\section{EIDER DUCK (Somateria mollissima).}

This species is only known as a winter visitor on the southern and western roasts of Englamb and Wales, hut it hreeds in suitable localities 
along the coasts of Scotland and on the Faroe Islands, off Northumberland. It is a great diver, the food consisting of shell-fish and crustaceans. Five to eight equgs of green colour (see British Bird Egro Cabinet, drawer 16) are laid in a nest mate of the stems of plants. grass and seatweed. usually sit uated among coarse herbage on low islands. During incubation, a lining of down, plucked from the breast of the female, is gratually added. The males take no part in incubation, and the duckis are left by the drakes directly they hegin to sit. The group exhibits the provision usually made for securing the nest hy having it lorlged in the middle of a rooted coarse plant. so that though built of light material in an exposed situation, it is held securely.

\section{Case 194.}

\section{TEAL (Nettion crecca).}

This species, which is the smallest of our British ducks, is more abundant during the winter months than in summer, but it breeds in almost every county in Great Britain and Ireland. In Lancashire all suitable heath-lands serve as breeding sites. At the duck decoy at Hale, an average of about 460 Teal are annually captured. It frequents fresh water, and feeds on the seeds of aquatic plants, grain, worms, slugs and insects, and the flesh is much esteemed as food. The nest, placed in tufts of coarse grass or heather on the borders of lakes or morasses, is composed of dry grass and leaves, lined with blackish down. Eight to fourteen ereamy white or pale buff eggs (see British Bird Egg Cabinet, drawer 13) are laid early in May.

\section{Case 195.}

\section{MALLARD oR WILD DUCK (Anas boscas). Local name: Mere Duck.}

This species was formerly more numerous in the British Islands than at present. A certain number still remain to breed, but they are comparatively few in proportion to the number of winter visitors. Several hundred are taken every year in the large decoy at Hale. The food consists mainly of grain or seeds, worms, slugs and insects. The Mallard is an early breeder, and the nest, composed of grass, lined with down, is usually placed on the ground, near the margin of rivers or lakes, but often at a considerable distance from water. The egges are a dull greenish grey colour (see British Bird Egg ('abinet, drawer 11), and the male does not participate in the incubation. The Mallard is the muloulted origin of the many varieties of our domestic ducks. 



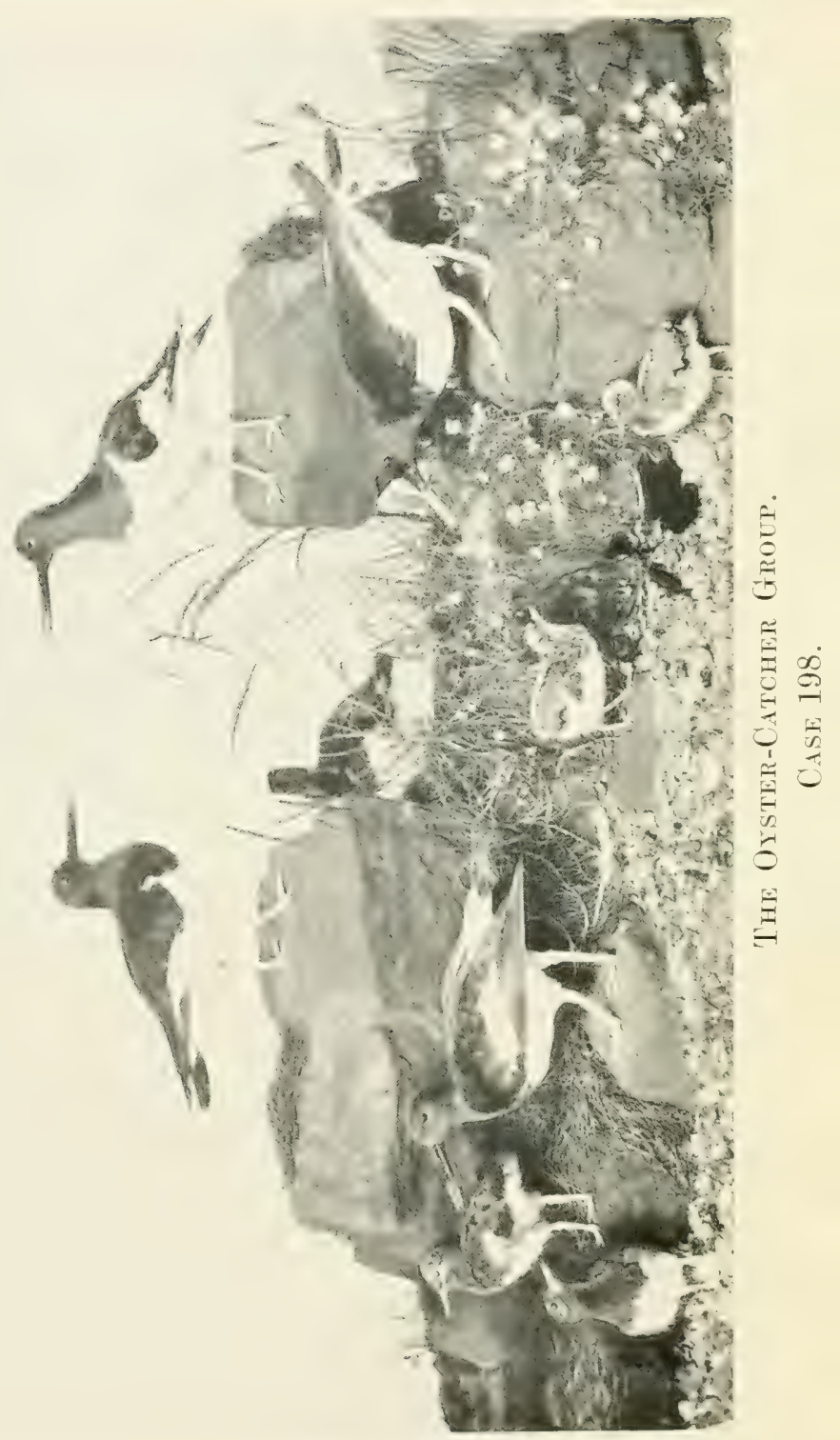




\section{Case 196.}

SHELD-DUCK (Tadorna cormuta).

Local name: Barrow Duck.

A resident species not uncommon on suitable parts of the coast of Great Britain and Ireland. Low sand-hills and mud flats are its favourite haunts, where small molluses, crustaceans, marine insects ancl other kinds of food are plentiful. In Lancashire, Formby sand-hills, the warrens near the Ribble and Walney Island are some of the nesting sites. Although the plumage is very similar in both sexes, the colours of the male are brighter and more defined. The nest is generally placed inside a rabbit burrow some feet from the entrance, and is made of bents with a thick lining of down from the breast of the female. Seven to twelve cream-coloured egos (see British Bird Ega ('abinet. drawer 11) are laid in Nay, and although the drake takes no part in incubation, he remains in the vicinity of the nest.

\section{Case 197.}

\section{RED-BREASTED MERGANSER (Mergus serrator).}

A winter visitor in considerable numbers to the larger estuaries in England and Wales, but in Scotland and Ireland it is resident and breeds more or less plentifully on the fresh-water lochs and on many parts of the coast. It is an expert diver, and feeds chiefly on trout, young salmon and other small fishes. The nest usually consists of a hollow in the ground thickly lined with down, but it is sometimes placed in an old burrow. It is usually well concealed among heather or long grass. The eggs, rarely more than ten in number, are laid towards the end of May, and are of a greenish-buft colour (see British Bird Egg C'abinet. drawer 14). The female undertakes the entire duties of incubation.

\section{Case 198.}

\section{OYSTER-CATCHER (Hæmatopus ostralegus).}

A common resident, frequenting the shores of the British Islands, but more numerous during the colder months of the year, when its numbers are increased by migrants from the continent. Its food consists mainly of mussels, whelks and limpets, which are extracted from their shells by the bird's powerful bill. No nest is made, but a slight hollow is usually scraped in the sand or shingle, on the seashore above ligh-water mark, or on the stony beds of rivers. The eggs, generally three in number, are pale brownish-buff, spotted and streaked with dark brown and ash-grey (see British Bird Egg Cabinet, drawer 20). 


\section{Case 199.}

COMLION SANDPIPER (Totanus hypoleucus).

Local names: Summer or Sand-Lark, Willie Liltie.

A regular visitor, arriving in April and departing in September. It is common in Ireland, Scotland and Wales, and in the northern and western portions of England. but less plentiful in the southern and rastern counties. In Lancashine it hreeds on the fells and uplands. The nest, made of dry grass and leaves, is placed in a hollow on the gromul, usually near fresh water. The four egges are of a creamy hutf colour, finely spotted with grey and with two shades of brown (see British Bird Egg Cabinet, drawer 21).

\section{REDSHANK (Totanus calidris).}

An autumn and winter visitant, occasionally seen in large flocks, but a few alwars resident throughout the rear. It breeds in marshy districts and pastures. nesting in a hollow in the ground among rushes. heather or long grass. The birds betrar great anxiety when the nest is approached, and endeavour to lead the intruder away by flying round and uttering their shrill and phantive note. The egges which are usually well concealed, are four in number, and are of a greenishbuff colour, blotched and spotted with purplish-brown (see British Bird Lgge (abinet, drawer 21). The nesting localities in Lancashire are few in number, Carnforth and Martin Marshes, Winster Valley and Walney Island among others.

\section{Case 200.}

\section{COMIION HERON (Ardea cinerea).}

Local names: Longricks, Jammy.

This speries is generally distributed throughout the British Islamb. The food consists of fish, frogs, reptiles, mice and voles as well as worms, molluses and insects. Although the Heron often leads a solitary existence on the coalsts and inland waters, during the breeding season numbers congregate together and form what are known as heronries. The most important heronries in this district are at Ince Blundell, near. Waterloo, Scarishrick, near Southport, and there are several flourishing colonies in Cheshire. The nests are generally placed on the tops of high trees: they are large flat structures formed of sticks and lined with roots, ete. The eggess, three to tive in number. are bluish green in colour (see British Bird Egg ('abinet, drawer 10). and are laid in March or in mild seasons much earlier. Both parents assist in tending on the young. 


\section{Case 201.}

LAPWING oR PEEWI'T (Vanellus vulgaris).

Local names: Peewit, Green Plover.

A common resident throughout the British Islands, but having its numbers greatly augmented in winter by large flocks from the continent. It frequents bare fallow and moorland, where worms, insects and slugs are abundant. The nest is merely a depression in the soil, scratched out by the birds, and lined with a little dry grass. The eggs, usually four in number, are very variable in colour, but rommonly brownish-buff, blotehed and spotted with blackish-brown (see British Bird Eigg (abinet, drawer 20). The egors are collected for the table. In the group notice how the colouration of the young Peewits blends with the surromenting foliage in which they are sheltering, rendering them most inconspicuous, and without doubt affording protection to them.

\section{DUNLIN (T'ringa alpina).}

Local names: Sea-lark, Sea-snipe, Oxeye.

This species is common on the shores and tidal rivers of the British Islands, throughout the year, and may be met with in large flocks feeding on the mud flats and sandbanks uncovered by the tide, during the winter months. In summer most of the adult birds move inland to the moorlands to breed. The nest consists of a slightly lined depression in the turf, situated among short heather or coarse grass. The eggs, four in number, are usually of a pale green colour, blotched and spotted with grey and reddish-brown (see British Bird Eggo (abinet, drawer 21).

\section{GOLDEN PLOVER (Charadrius pluvialis).}

Although many are resident, the species is most plentiful during the periods of migration and in winter, when vast flocks frequent the pastures and coasts in search of food insects, worms, molluses, etc. The birds retire to the moors to breed, about March. The nest is merely a slight hollow in the ground, usually among heather or short gratss. The four eggs are yellowish-huff, handsomely blotehed and spotter with puplish-brown and hrownish-black (see British Bird Egg Cabinet, drawer 20). It is interesting to note that after the antumm moult the black underparts are replaced hy white.

\section{SNIPE (Gallinago colestis).}

('ommon throughout the British Istands esprecially in Scotland and Ireland, frequenting marshy districts. It is more numerous during the colder months of the yaar, when numerous flights arrive from the 
continent and remain until March. Insects, worms and molluses form its food, and in frosty weather it is frequently forced to shift its quarters in seareh of open spound where food may be obtained. The nest merely consists of a lining of dead glass in some hollow in the gromel, situated among rushes, grass or heather. The four ergs are generally greenish-buft, spotted and blotehed. especially at the larger end, with light and dark brown and grey (see British Bird Egg Cabinet, drawer 20).

\section{Case 202.}

\section{COMMON TERN (Sterna fuviatilis).}

Local name: Sea Swallow.

This summer visitor reaches our coasts towards the end of April, and returns to the South between August and October. They are somewhat gregarious in habit, and numerous breeding stations are seattered along the eoasts of the British Islands as well as on inland lochs. The food is mainly small fish, shrimps and other crustacea, and like the Aretic Tern it plunges into the sea after its prey. Two or three egus are laid, and they vary greatly in colour and markings (see British Bird Egg ('abinet, drawer 22). They are deposited above high water mark among the shingle, and their colouration as well as that of the newly hatched young, closely resembles the tones of the surrounding water worn pebbles. This example of protective colouration is well illustrated in the group.

\section{ARCTIC TERN (Sterna macrura).}

This summer visitor reaches the British Islands at the end of April, and departs southwards in the autumn, the migrations lasting from August to October. Large colonies breed round the coasts of Great Britain and Iretand, but in the north of Scotland it is most numerously represented. In food and habits it resembles the Common Tern. Two to three eggs are laid and vary greatly in colour markings (see British Bird Eggr ('abinet, drawer 22). They are laid in depressions in the sand or shingle.

\section{LITTLE TERN (Sterna minuta).}

This, the smallest of our terns, arrives early in May, and leaves in September or early in October. Its food is similar to the Common Tern. The breeding stations on the flat sandy or shingly shores are scattered along the coasts of the British Islands. Two or three stonecoloured egges are laid towards the end of Nary in hollows in the samd or shingle (see British Bird Egog (abinet, drawer 22). In the group 


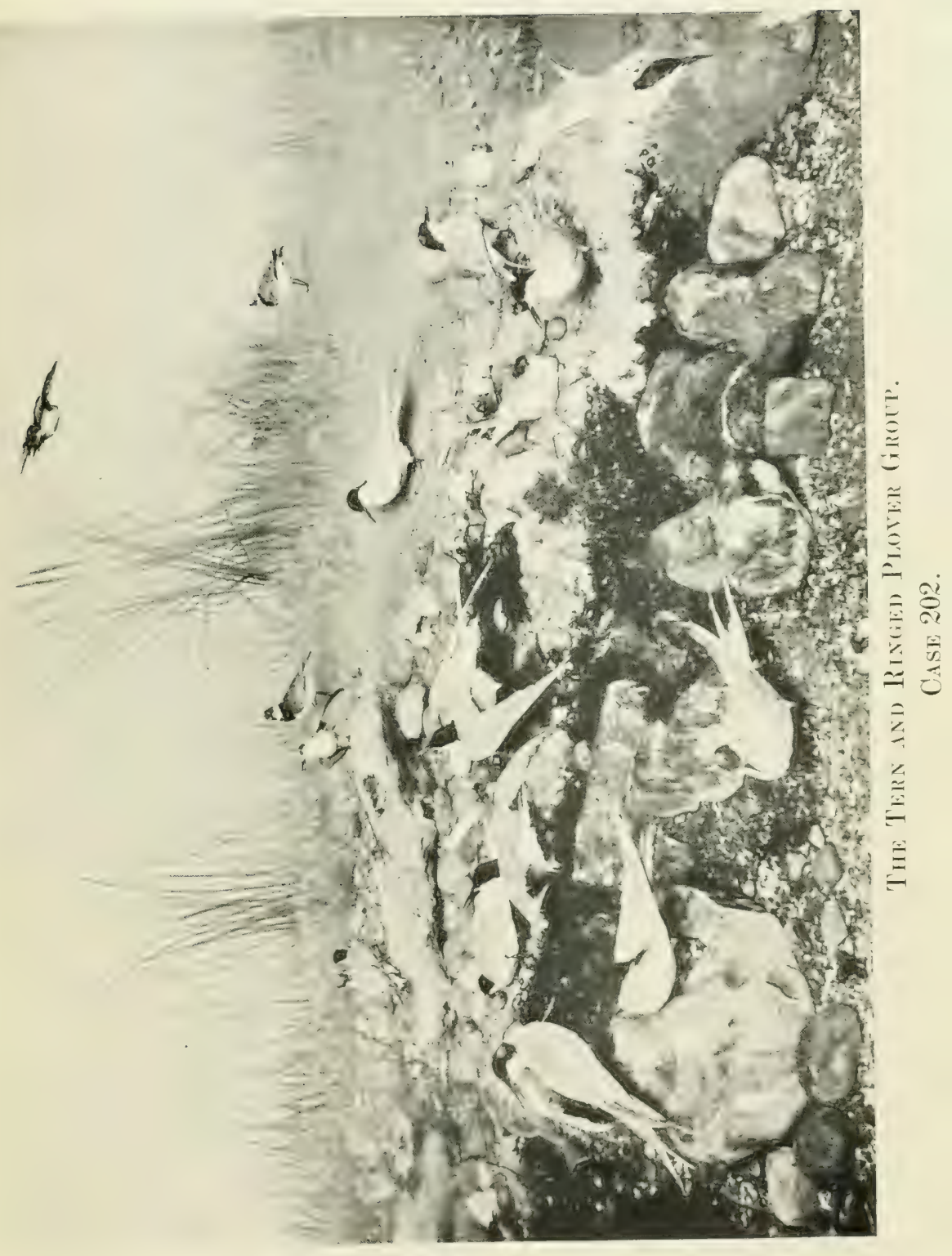



three recently hatched chicks are shown near the log of wood, and the colour of down harmonizes so well with the colour surroundings that they are not seen without careful looking.

\section{RINGED PLOVER (Egialitis hiaticola).}

There appear to be two laces of Ringed Plover. The latger race, sometimes called the Ringed Dotterel, is more or less resident and inlabits the flat sandy portions of our coast. The smaller race visits our shores for a brief periorl in spring. The four egos are latid in a hollow in the gromed often lined with tragments of shell. They are pale buff or stone-colour spotted with black or grey (see British Bird Egg Cabinet, drawer 20). Two broods are usually reated in a season. Here again the egrs and roung so closely resemble their surroundings that they are difficult to find.

\section{Case 203.}

BLACK-HEADED GULL (Larus ridibundus).

Local names: Chir-maw, Cockle Maw, Laughing Gull.

A common resident, abundant on our inlaud waters in great and increasing numbers. This Gull is a useful friend to the farmer, feeding on grubs and other injurious insects. In spring it resorts to the breeding places, where it congregates in large numbers. The "galleries" as they are called, are found in marshy localities or on inland lakes, and are resorted to year after year. The nest, made of sedge, flags, ete., is placed on the ground or on clumps of rushes. The eggs, three or four in number, varying greatly in colour markings (see British Bird Egg Cabinet, drawer 22), are laid tomards the end of April, and in many places are collected for the market.

\section{Case 204.}

\section{LESSER BLACK-BACKED GULL (Larus fuscus).}

A resident, common on all the coasts of the British Islands during the greater part of the rear. but somewhat local in its distribution during the breeding season, when large numbers congregate on moors, turf-clarl slopes, or tlat-topped islands. Being almost ommivorous, and especially partial to the ecres and roung of gamp-linds and water-fowl, it is constantly destrored by gamekeepers. The nest is made of grass, dry seaweed, etc., and three eggs are laid early in May, and vary greatly in colour and markings (see British Bird Egg ('abinet, drawer 23). In Lancashire, the nesting places are confined to small colonies, "on the low gromeds near the estuary of the Kent" (Mitchell, "Birds" of Lancashire," p. 250) ; also on Maluey Tsland and Foulshaw Moss. near Morecambe Bay. 


\section{Case 205.}

KITTIWAKE (Rissa tridactyla).

The "Kittiwake" a trivial name derived from its note, is generally distributed along the coasts of the British Islands throughout the winter months, but in summer it resorts in vast numbers to rugged cliffs for the purpose of nesting. Large breeding colonies are to be

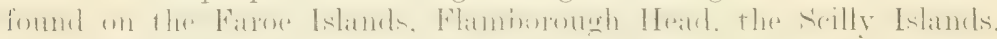
Lundy Island, and around the coast and islands wherever cliffs may be met with. The nest, usually formed of seaweed and lined with grass, is placed on a ledge of rock, and contains two or three pale-buff

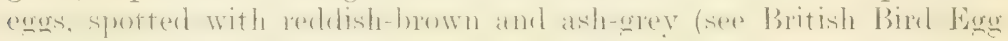
Cabinet, drawer 23).

\section{Case 206.}

\section{COMMON GULL (Larus cames).}

demerally distributed alonge the roasts of the British Islands and frequently seen inland during the colder months of the year, but in April the majority move northwards. It is not known to nest in England or Wales, but in north Britain and parts of Ireland large colonies are numerous. Open woods, islands in lakes, and the less precipitous coasts are the favourite breeding places. When at sea the food is mainly fish, but when inland the birds may be frequently seen following the plough in searh of worms and grubs. The some what large nest is made of any convenient material such as grass, heather or seaweed. The eggs, three in number, are laid early in May, and vary greatly in colour, but are generally olive brown, spotted with dark brown (see British Bird Egg Cabinet, drawer 22).

\section{Case 207.}

\section{HERRING GULL (Larus argentatus).}

Local name: Silver Gull.

A resident, abundant on the coasts at all seasons, and breeding wherever precipitous rocks or isolated "stacks" afford a suitable refuge. Nany pairs also nest among the sandhills on the north-east coast of Scotland, and some colonies may be found on the islets in lochs. This species generally nests in company with others of its kind, and often among colonies of the Lesser Black-backed and

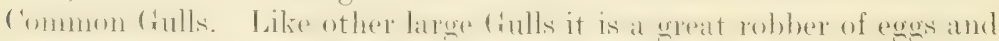
young birds. The nest is formed of grass, and the eggs, three in number, are of a stone colour, or light olive brown, blotehed and

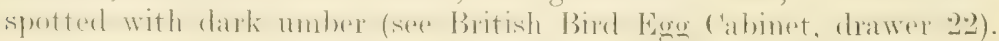
In Laneashire the nesting places are few in number. mainly at Foulshaw 



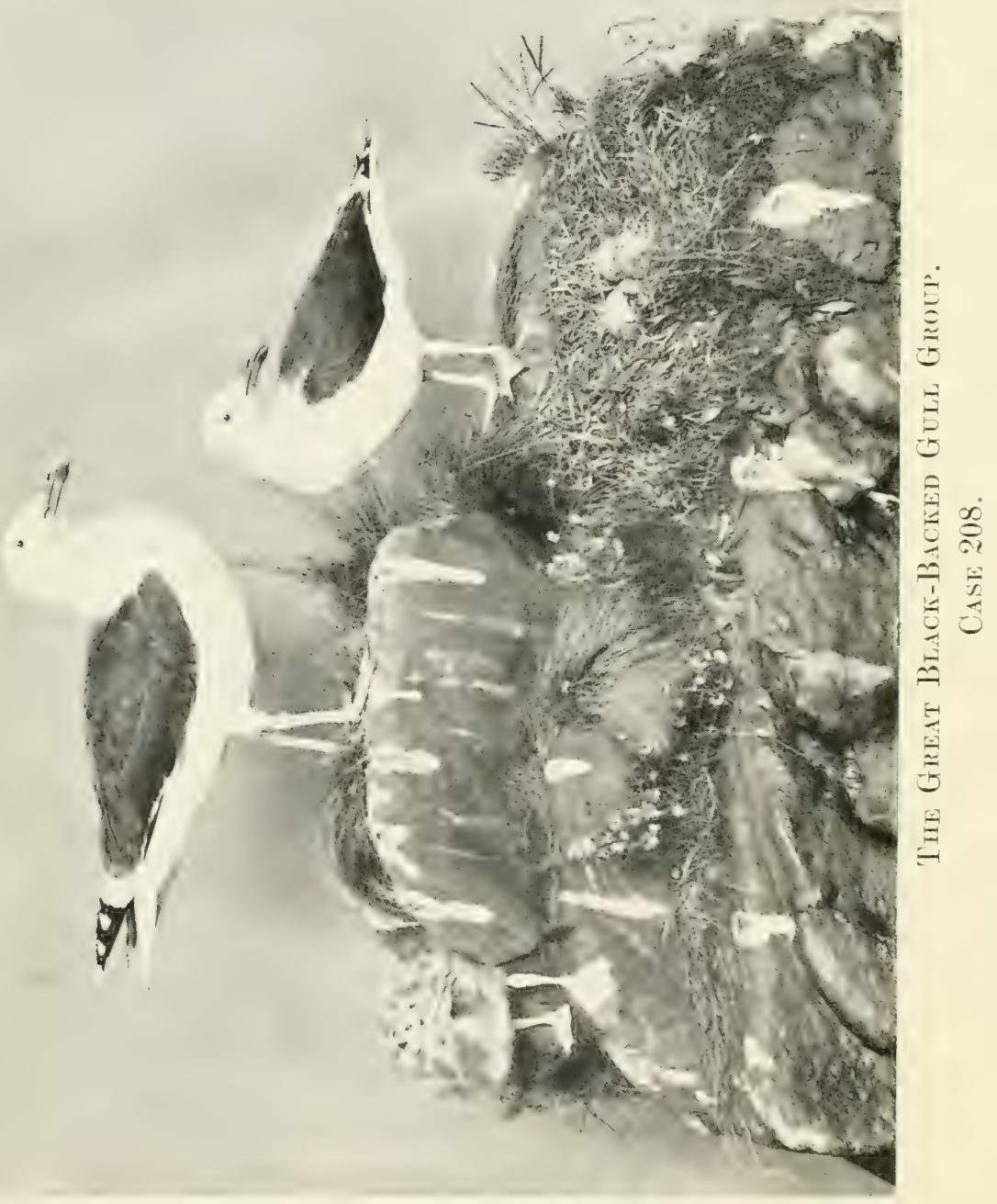


Hoss, near Morecambe Bay. Fxampless of the various changes of plumage of this ciull, from the chick to the adult plumage of a five year old Gull, may be seen in Case No. 229.

\section{Case 208.}

\section{GREAT BLACK-BACKED GULL (Larus marimes). \\ Local name: Devoke water maw.}

The largest of our resident species. frecunently seen on the IIersey during the winter, and numerous a few miles of the shore all the rear round. It breeds in small numbers on the south and west coasts of England and in Wales, hut is common in many parts of teotland and Ireland. It feeds largely on animal food, attacking sickly sheep and lambs, devouring the young and egges of game-birds and water-fowl. as well as carrion. The roughly constructed nest. mate of seaweed. dry grass, etc., is usually situated on isolated stacks or on an islet in some sechuded mountain loch. In Lancashipe it nests on Piling Moss and on the fells near Rusland, not far from Morecambe Bay. The equs, two or three in number. are lorownish-buff. blotehed with umber and dark-grey (see British Bird Egg Cabinet, drawer 23).

\section{Case 209.}

\section{PUFFIN (Fratercula arctica). Local names: Coulterneb, Sea-Parrot.}

Large numbers of this species breed in the cliffis and grassy slopes on many parts of the coast-line of the British Islands. Towards the end of iugust. when the young are ready to follow their parents into the water, they leave the coast for the open sea, where they pass the winter, returning to their breeding places in IIarch or April. The single dull-white egre, faintly spotted with brown or lilas (see British Bird Egg Cabinet, drawer 25), is laid in a crevice of a rock, or in a rabbit burrow or a hole made by the bird. The young are fed on small fishes. which are carried transversely in the bill of the parent, six or eight being brought at a time.

\section{Case 210.}

\section{BLACK GUILLEMIT'T (Uria grylle).}

The Black (ruillemot closely resembles the common Guillemot in habits. It is a bird of the sea, diving and swimming under water with great rapidity, and it only visits the rocks for breeding purposes. Its food is principally composed of the frr of fish, especially the Coal Fish and Herring. It breeds on the west of seotland, the Hebrides, the Orkners and Shetlands. and a few pairs may he seen in the Isle of Man. No nests are made, the eggs being generally placed in the crevice of a rock. They are two in number and are coloured white or 
greenish-white, with black spots generally distributed, and with very distinct underlying spots and blotches of purplish-grey (see British Bird Egg Cabinet, drawer 25).

\section{Case 211.}

\section{RAZOR-BILL (Alca torda).}

The Razor-bill closely resembles the Guillemots in its habits, and is generally distributed along rocky coasts from Cornwall to the Shetlands. It is most at home in the water where it vies with the fish, on which it feeds, in activity and rapidity of movement. In summer it comes to the rocky headlands and wild precipitous coasts to rear its young. One egg only is laid. differing in shape from that of the Guillemot and not having the same range of variation in colour (see British Bird Egg (abinet. drawer 25), and they are usually placed in more sheltered positions, such as corners or hollows among rocks or projecting boulders.

\section{Case 212.}

\section{COMMON GUILLEMOT (Uria troile).}

The Guillemot is found throughout the rear frequenting the open seas surrounding the British Islands. It is an expert diver, and the wings are used for propulsion under the water, in search of fish on which it feeds. In Jareh rast numbers make for land and assemble in immense colonies for breeding purposes. Island cliffs or precipices form their accustomed nesting places, and a single pear shaped egg, varying greatly in colour and markings (see British Bird Eggr Cabinet, drawers 25 and 26), is laid in May or June on an open ledge of rock. The female usually sits facing the eliff, and the egg is held between her legs with the point outwards.

\section{Case 213.}

\section{COOT (Fulica atra).}

Local name: Lake-Hen.

A resident species, found in suitable situations throughout the British Islands. Locally, it mav be seen frequenting and nesting on our various lakes and in all reedy tarns and pools. In severe weather it migrates to the sea-coast. The food consists of aquatic insects, worms, molluses and vegetable substances. The nest, made of dry reeds and sedges, forms a deep compact mass, and is generally placed above shallow water, among tall rushes. The eggs are buff-colour with small spots of blackish-brown (see British Bird Eggg Cabinet, drawer 19), and are usually seven to ten in number. The nest seen in the group was collected from Knowsley Park. 


\section{Case $213 a$.}

This duplicate case of the c'oot is shom because of its historical interest. It is the first case of its kind mounted so as to show the characteristic habitat of the species. It was prepared in 1865, and was exhibited at the British Association Meeting, held in Birmingham the same year.

\section{Case 214}

\section{IIOOR-HEN (Gallinula chloropus).}

A common resident throughout the British Islands, found wherever the reedr margins of lakes, ponds. or rumning water attord suitable shelter. It is a good swimmer and feeds on slugs. worms and insects, and has been known to kill and devour the voung of ot her water fowl. The nest is usually situated just above shallow water among reerls or other aquatic plants, but it is oecasionally placed a considerable height over the water in the branches of some overhanging trees. It is a compactly built structure, made of dry flags and sedges. The egos, from seven to nine in number, are pale-buff. spotted with redrlish-brown and dull lilac (see British Bird Egg Cabinet, drawer 19).

\section{Case 215.}

\section{GREAT CRESTED GREBE (Podicipes cristatus).}

This species is more or less resident in England and Wales. In winter it is to be found on many parts of the British Coasts. It feeds on fish and crustaceans and sometimes on tadpoles and frogs. The nests may be found on the more extensive and reedy sheets of water, and are usually floating masses of wet aquatic plants. Four or five white egos are laid, but they soon become stained to a vellow-brown from contact with the wet decomposing vegetable matter (see British Bird Egg Cabinet, drawer 21). The (treat Crested Grebe has an instructive habit of covering her eggs with shavings made from the surrounding bullushes, when she leaves the nest. These shavings are prepared by the bird while sitting on the eggis. and in the gromp the heap of shavings and the stumps from which they have been talien are shown. The nest was collected from the lake at Knowsley Hall. The muptial adormments - the crest and tippet- disappear at the autumn moult, and the top of the head and hack of the neck become brown. and the throat and fore-neck silvery white.

\section{LITTLE GREBE or DABCHIT (Podicipes fluriatilis).}

A common resident throughout the British Isles. It may be found frequenting all reely streams and lakes. Its food consists 
mainly of fish, inseres and regetable matter. 'The rather largenest is made of reeds and decaying weeds, interwoven with and anchored by some aquatic plant or shrub. Four to six creamy-white eggs are laid. which som berome stamed hy contart with the damp vegetable matter of the nest (see British Bird Huge ('ahinet. drawer 21). The Little Grebe has a habit of covering her eggs when leaving the nest with water weeds and rushes, so adding continuously to the bulk of the nest. In winter the chestnut colouring of the side of the neck and head is replaced by uniform white, and the crown is brown and the under parts of the body much paler.

\section{WATER-RAIL (Rallus aquaticus).}

This speries mav he regarder as a resident. for though some of our native birds move southwards in autumn, their place is taken by others from the Continent. It frequents marshy districts and its principal fornt comsists of worms. molluses and arpatic plants. The nest is well concraled among rushes or erarse herbage, and the material of which it is made, flat leaves of reeds and sedges, harmonises well with its smommdings. Seren to eleven esss are laid. and they are pale creany-white. spotted with reddish-brown and ash-grey (see British Bird Egg Cabinet, drawer 19). The young when first hatched, are covered with black down, and two broods are reared in a season.

\section{Case 216.}

\section{RED-THROATED DIVER (Colymbus septentrionalis).}

Adult birds of this species with the white throat characteristic of the winter plumage, are commonly met with in the winter on all our coasts. The only places in which it is known to breed in the British Islands are the north of Freland and in parts of seotland. The female is rather smaller than the male, but in plumage is almost similar. This species prefers small lochs and prols for nesting, and is seldom seen on the larger lochs except in search of fish on which it mainly feeds. The large olive-brown eggs, spotted with dark brown (see British Bird Eger ('abinet, drawer 2t) are laid on the hare and often wet ground, close to the water's edge. The male shares the duties of incubation.

\section{Case 217.}

\section{BLACK-THROATED DIVER (Colymbus arcticus).}

An annual winter visitor in small numbers to this district, but tolerably common during the breeding season about the larger lochs of the north and west of Scotland. In winter the plumage is entirely 


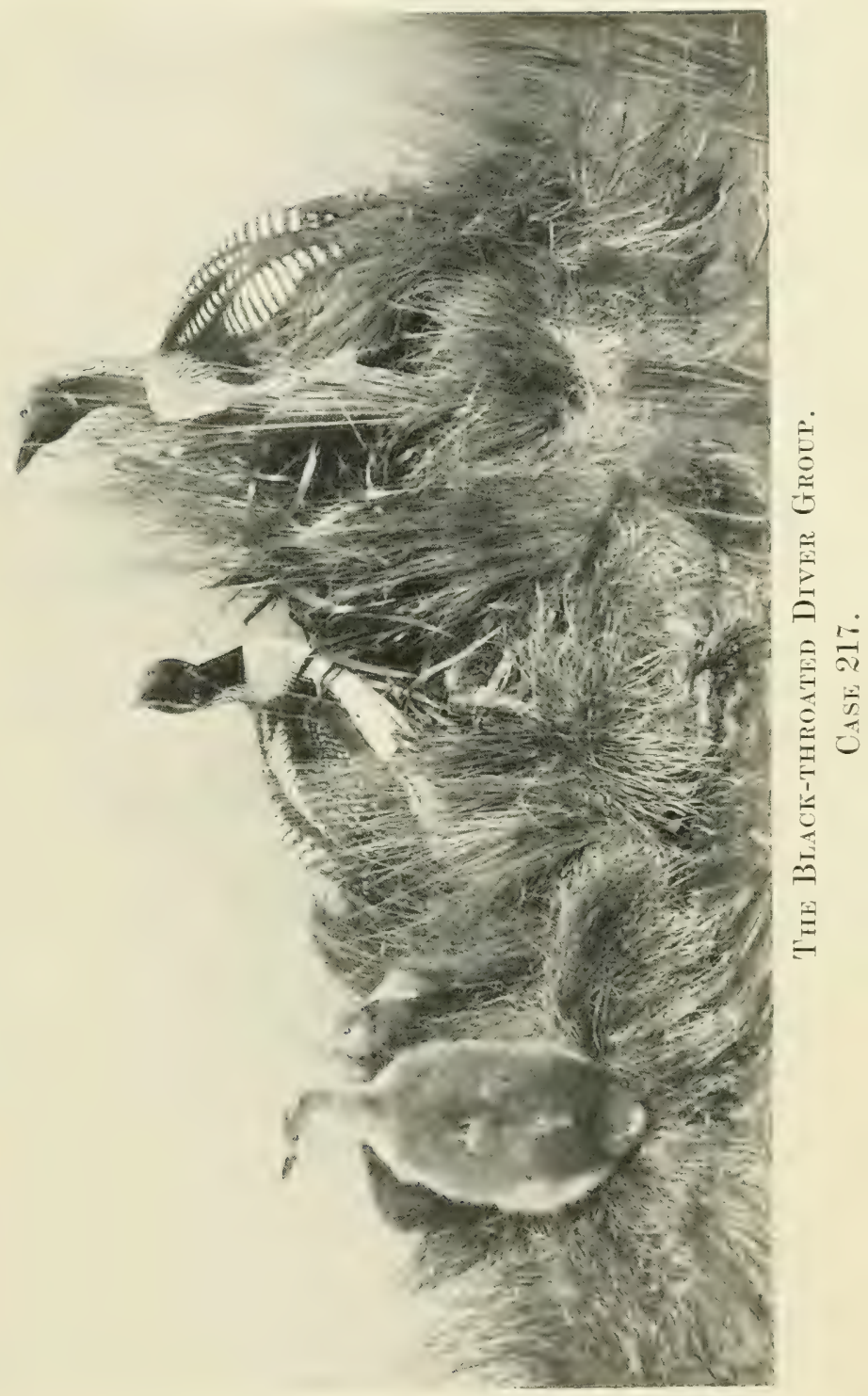



alferent frem that of spring. for after the attumm moult, the appres. parts become ashy-brown and the under parts white. The flight is very strong and rapid, and the movements both on and below the surface of the water are active and varied, though slow and awkward on land. Fish, which mainly form its food, are captured by diving; and subsequently brought to the surface and swallowed. The nest, generally situated chose to the water's extge, consists of merely a hollow in the ground, with little or no lining, either on some grass grown island. of on the mainland. Two olive-hown regs. suntert with black (see British Bird Egg Cabinet, draver 24) are laid in May.

\section{Case 218}

\section{TURTLE DOVE (Turur communis).}

A summer visitor generally arriving about the hegimning of Mat a and departing in september. Its numbers seem to he reatr increasing and it is now found in many localities in which it was formerly entirely absent. Although a few years ago it was hardly known in (heshire. it is now a common summer visitor to most parts of Wirral. The flat, slighty eonstructed nest of twigs is placed in a thich hush. usually at no

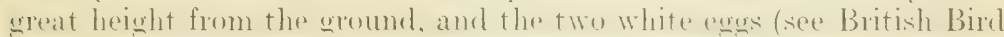
Egrge (abinet. drawer 17) alre laid towalds the end of May. The nest. here shown was collected at Heswall, Cheshire, in 1911.

\section{Case 219.}

\section{RED-LEGGED PARTRIDGE (Caccabis rufa).}

This species is now a local resident in the eastern and midland founties and is gradually extending its range in all directions. They

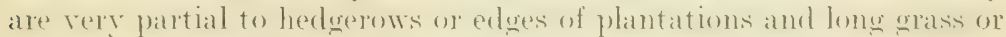
rushes, and when flushed. orasionally pereh on a neighbuming trees. which the grey partridge is believed never to do. The nest is merely a hollow scratched in the ground under the shelter of a hedge or of tall herbage. The eges (see British Bird Egre (abinet. drawer lis). ten to

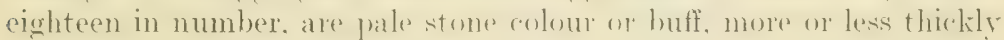
spotted-sometimes blotched, with dark reddish brown.

\section{Case 220.}

\section{ROCK DOVE (Columba livia).}

This species is resident and common along the rocky coasts in the morth of Great Britain and Ireland. Where caves and deep fissuress exist. and afford suitable resorts. Somewhat similar in size and weight to the Stock Dove, it mas be distinguished hy the white rump) (instead of blue). 
and by the black bars on the wings. The nest, composed of dry seaweed, srass or other material, is generally placed on the ledge of some deep carren. Two white eggs (see British Bird Ego Cabinet, drawer 17) are laid at each sitting, and sereral broods are reared during the rear.

From this species all the domestic varieties of Pigeon have been derived (see Case 230).

\section{Case 221.}

\section{RED GROUSE (Lagopus scoticus).}

The Red Grouse is peculiar to the British Islands. It is the insular representative of the Willow Grouse (L. layoprs) of northern Europe, Asia and America, but it does not assume a white plumage in winter. It is generally distributed over the moors, especially in the north of England and heotland. Its food consists of berries and grain and the tips of the ling and heather. Eight to ten eggs (as many as fifteen have been foumd) are laid in a hollow among heather. They are whitish-buff, heavily mottled and blotched with reddish-brown (see British Bird Egg Cabinet, drawer 17). Incubation takes about twenty-four dars, and the young, when hatched, are carefully tended by both parents.

\section{BLACK GROUSE (Tetrao tetrix).}

This species was formerly much more common in England. It is now comparatively scarce, except in the south-western districts. It frequents youmg plantations of fir. larch and birch in the neighbourhood of moorland. Its food consists mainly of berries, seeds and the buds of trees and plants. The male, known as the Black-cock, is polvgamous and takes no share in the incubation of the eggs and care of the roung. The female or Grey-hen makes a slight nest in a concealed hollow, and lays from six to ten eggs of a creamish-white colour, spotted with orange brown (see British Bird Egg Cabinet, drawer 17).

\section{CURLEW (Numenius arquata).}

This species is a common resident thoughout the vear. Although usually frequenting the coast, in spring the adult hirds retire inland to the moors and uplands for nesting purposes. The food as a consefuence varies, consisting of berries, worms, molluses, ete., in summer and crustaceans and other marine animals in winter. The nest is usually situater among heather or grass, and consists of a slight hollow in the ground, lined with bits of dry herbage. Four large pear-shaped egges are laid, varying in tint from olive green to brownish-buff, spotted and blotehed with brown and purplish-grey (see British Bird Egg Cabinet, drawer 21). 


\section{Case 222.}

\section{COMMON PHEASANT (Phasianus colchicus).}

This well-known resident is genterally distributed thronghout the British Isles. It frequents thick covert-woods with plenty of undergrowth, in the immediate neighbourhood of cultivated land, where in the morning and evening the birds can come out to feed. The chief food consists of grain, seeds, berries and young shoots, varied with insects and grubs, wireworms being a favourite morsel. The nest is a mere hollow in the ground, roughly lined with dearl leaves and well concealed. The eggs (see British Bird Eugg ('abinet, drawer ls) vary in number from eight to twelve, but a score or more are sometimes found in one nest, probably the produce of more than one female.

There is little doubt that if the Pheasant were not artificially reared and annually turned down in this comntry it would soon cease to exist, for in hard winters especially, the hirds left for stock are largely dependent on artificial feeding.

\section{COMLION PARTRIDGE (Perdix cinerea).}

A generally distributed resident, being especially abundant in the south-eastern counties of England. The food consists of green leaves, seeds, grain and many species of insects and snails. The wellconstructed nest consists of a hollow in the ground, lined with leaves, etc. From twelve to twenty eggs are laid towards the end of April or the beginning of May (see British Bird Egg (abinet, drawer 18). Incubation lasts from twenty-one to twenty-three lars, and the young are carefully tended by both parents.

\section{WOODCOCK (Scolopax rusticula).}

Though generally regarded as a migrant, which arrives in October and returns northward in March, many specimens of this species remain to breed. It is generally distributed, freguenting wooded districts. The Woodcock provides a good example of protective colouration in which the colour of the plumage is aided by the crouching habit of the birct. so that it is almost invisible when among the dry autumn leaves and brushwood which it frequents. This is well illustrated in the exhibited specimen in the case. The food consists mainly of worms, of which enormous numbers are eaten, the bill being specially adapted for burrowing after them in the soil. Any rounded depression in the ground, in some sheltered spot, serves as a nest, merely lined with dry leaves. Four eggs are laid (see British Bird Egrg (abinet, drawer 21). of a creamy buff, blotched and spotted with grey and reddish-brown. The Woodcock has heen observed carring its roung when on the wing-the nestling being held with the aid of the legs and bill. 


\section{LAND RAIL oR CORN-CRAKE (Crex pratensis).}

A well-known visitor anriving in the south of England about the end of April and learing usually hefore the end of September. During this time it is willely distributed throughout the British Isles, frequenting Erass-land and "ultivated fields. The harsh call-note of the male is familiat to most people. but the bird is seldom seen owing to its retiring habits. The foont consists of slugs, insects and worms as well as seeds. The nest is placed on the ground among standing crops of erass, elover, etc., and is made of piecess of dry plants. Seren to ten buffi-roloured roge (see British Bird Eugg ('abinet, drawer 19), spotted with pale lavender and reddish-brown, are laid towards the end of May.

\section{Case 223.}

\section{CAPERCAILLIE (Tetrao urogallus).}

This species, although originally indigenous in the British Islands, berame extinct in this country in the middle of the 18th century, but was re-introduced from Sweden, and it is now abundant in the pine and beech forests of the central districts of Scothand. Its principal food consists of the tender shoots of the Scotch fir, together with beries and grain. The flesh, especially of the older birds, is strongly flavoured with turpentine. Its nest is a hollow scraped in the ground near a tree or bush, and the eggs (see British Bird Egg Cabinet, drawer 17) are a pale reddish-yellow, spotted with brown, and in number from six to twelve. The male takes no part in the duties of incubation or of rearing the young.

\section{Case 224.}

RING DOVE or WOOD PIGEON (Columba palumbus).

\section{Local names: Cushat, Queeze.}

A generally distributed resident in the British Islands, in all wooded districts where its numbers have greatly increased in recent years. In winter immense flights arrive on our east coasts from the continent, greatly increasing the numbers of these voracious bircls, which cause serious loss to agriculturists. A slightly built nest of twigs, is placed on the branches of almost any kind of tree or bush. Two or three bronds are reared ammually, the first pair of white eggs (see British Bird Egg (ahinet, drawer 17) are generally laid in February or March, and in farourable seasons nests containing eguss or young birds may be found during every month in the year.

\section{STOCK DOVE (Columba aenas).}

A common resident, which has greatly increased in numbers of late vears, extending its range northward so that it is now plentiful in many parts of the morth of sicotland. The nesting sites vary greatly. 
In timbered districts, holes in trees are generally nect. but in treeless areas, rabbit burrows (as here shown), the shelter of dense furze, overhanging ivy on cliffs and walls are made use of. Sometimes a small quantity of dried roots are used, barely sufficient to keep the egas from the ground, but generally they are placed upon the hare sand, especially when laid within the entrance of rabbit burrows. Two white egges (see British Bird Eugg (abinet. drawer 17) are laid and several broods are raised during the year.

In Cases 225 to 229 there are examples of birds that do not breed in the neighbourhood, regular winter visitants, and birds that have only been recorded on rare occasions.

\section{Case 225.}

NUTCRACKER (Nucifraga caryocatactes).

The Nutcracker has been observed 40 times south of the Tweed, 3 times only in Scotland, and not at all in Ireland. It has been recorded locally but once-at Vale Roval, Delanere, ('heshire, 1860). This specimen is now in the Grosvenor Museum, Chester. (c)ward. "Birds of Cheshire," p. 98). For eggs see Case 231, drawer 28.

FIELDFARE (Turdus pilaris).

An autumn and winter visitor; may be often seen in large flocks in the Nersey Valley. For eggs see Case 231, drawer 28.

REDWING (Turdus iliacus).

A common winter visitor. For eggs see Case 231, drawer 28.

BLACK REDSTART (Ruticilla titys).

A winter visitant to Great Britain. Locally rarely seen.

ROSE-COLOURED PASTOR (Pastor roseus).

The Rose-coloured Pastor is a vagrant in the British Islands. It oceurs fairly frequently, and there are sereral reeorded instances of its occurrence, viz. Ormskirk, 1821: Salford, 1829: Ecrles, 1830, 1831 (locality not cited): Liverpool. 1840: ('artmel. 1854: ()ldham. 1860; and from Prestwich ('lough, Heaton Park and Barlow Wood, on the south of Uanchester. (Mitchell, "Birds of Lanciashire," p. 77). For eggs see Case 231, drawer 28. 
Case 225-continued.

GOLDEN ORIOLE (Oriolus galbula).

This species breed in Cornwall, there are records of its nesting in six other English counties, but it is only recorded as a rare visitor to this locality. For eggs see Case 231, drawer 4.

\section{WAXWING (Ampelis garrulus).}

An irregular visitor to the British Islands. Invasions of the bird have occasionally occurred to the local area. The upper specimen of the two on exhibition was shot at Simonswood, near Liverpool. For eggs see Case 231, drawer 28.

\section{PIED FLYCATCHER (Muscicapa atricapilla).}

A summer visitor; few breed in the local area. For eggs see Case 231, drawer 4.

\section{GREAT GREY SHRIKE (Lanius excubitor).}

An annual autumn and winter visitor to the eastern side of Great Britain, and only an occasional visitor to the local area. A female was shot at Urmston in January, 1904 (Zoologist, 1904), and specimens were taken at ('horlton in 1905, Sale, ('headle in 1850), Delamere Forest in 1886, and Dorleston, Nov. 9th, 1893. A specimen from Middlewich is in the Warrington . Museum. (Coward, "Birds of Cheshire," p. 66). For eggs see Case 231, drawer 28.

\section{WHITE WAGTAIL (Motacilla alba).}

The White Wagtail passes through the British Islands from the middle of March to the early part of June, being chiefly noticed in the coastal regions of the western side of Great Britain and Ireland. It has been recorded in the local area in 1869, at Burton. (Coward "Birds of Cheshire," p. 62). For eggs see Case 231, drawer 3.

\section{SHORE LARK (Otocorys alpestris).}

An exceedingly rare winter visitor. Several records from Lancashire and Cheshire.

\section{BRAMBLING (Fringilla montifringilla).}

A winter visitor to the British Islands, and an occasional visitor to the local area. For eggs see Case 231, drawer 4.

\section{HOOPOE (Upupa epops).}

A passage-migrant to the British Islands. The specimen exhibited in the case is one of four shot at Knowsley Park in 1815. There are 
Case 225-continued.

a dozen other records of its occurrence in the local area, viz, at Sale, Hoylake and Hanchester ('oward. "Birds of ('heshire," p. 117), 1905, and Walney Island, 1881 (Mitchell, "Birds of Lancashire," p. 97). For eggs see Case 231, drawer 7.

\section{HEALY REDPOLL (Linota linaria).}

An irregular autumn and winter visitor. For eggs see Case 231, drawer 28.

\section{PINE GROSBEAK (Pyrrhula enucleator).}

A rare vagrant. There have been fifty more or less authenticated records, of which two near Hurlston in 18.37 were local. (Mitchell. "Birds of Lancashire," p. 69). For egges see (ase 231, dratwer 28.

\section{ROUGH-LEGGED BUZZARD (Buteo lagopus).}

Once a common visitant but now rare. Five specimens were shot locally in 1880. For eggs see Case 231, drawer 30.

\section{KITE (Milvus ictinus).}

The Kite was formerly abundant in (rreat Britain, but it is now confined to Wales and is a very rare vagrant elsewhere. At one time it nested in the tall trees among the fells, but it has not appeared during the last 25 years. Although formerly a common resident in the Cheshire woodlands, it has only been noticed very occasionally within recent years. For eggs see Case 231, drawer 8.

\section{HONEY BUZZARD (Pernis apivorus).}

The Honey Buzzard is an uncomnon passage-migrant in May, September and October. It is more frequently seen in the eastern counties. The two specimens in the case are local, the immature female being shot at Knowsley Park by the Hon. E. C. Stanley, in October, 1818, and the adult female at Rainford, in 1835. It is now a very rare visitor to the local area.

\section{MONTAGUE'S HARRIER (Circus pygargus).}

A rare summer visitor in the British Islands. It has been recorded twice locally Wahey Island in 187t (Mitchell, "Birds of Limeashire," p. 107), and Whitendale MIoor, 18s9 (Mitrhell, "Birds of Lancashire." p. 123). For eggs see Case 231, drawer 8 .

\section{GREENLAND FALCON (Heirofalco candicans).}

An irregular winter visitor. There are no local records. 
Case 225-continued.

\section{MARSH HARRIER (Circus aruginosus).}

A casual visitor. For eggs see Case 231, drawer 8.

\section{HEN HARRIER (Circus cyaneus).}

The Hen Harrier is a British resident and a winter visitor. and nests from time to time among the fells. For eggs see Case 2:31, drawer 8.

\section{HOBBY (Falco subbuteo).}

A summer visitor in the British Islands, but rare locally. For egess see Case 231, drawer 8.

\section{GOSHAWK (Astur palumbarius).}

A rare vagrant; there are only two local records. For eggs see Case 231, drawer B.

\section{SCOPS OWL (Scops giu).}

A casual straggler to the British Islands. The two local area records are Boggart (lough about 1850 (this specimen is now in the Peel Park Museum) (Mitchell, "Birds of Lancashire," p. 105) and Cardon Park in 1868 (Coward, "Birds of ('heshire," p. 126). For eggs see Case 231, drawer 29.

\section{TENGMALH'S OWL (Nyctala tengmalmi).}

Tengmaln's Owl has its home in the far north and has occasionally straggled to the British Islands in very cold winters. A specimen is recorded as having been taken near Preston, which is now in the Nottingham II seum (Mitchell, "Birds of Tancashire." p. 104). For eggs see Case 231, drawer 29.

\section{LITTLE OWL (Athene noctua).}

The Little Owl is now resident as an introduced bird. There are about twenty early recorded examples which may have been genuine vagrants (I)r. Hartert). Locally there is one record by Mr. T. Williams, of ()rmskirk, in 1863, at Bathwood. ()rmskirk. For ergas see ('ase 2:)1. drawer 7 .

SNOWY OWL (Nyctea scandiaca).

A rare winter visitor. There are no local records. For eggs see Case 231, drawer 7 .

\section{SHORT-EARED OWL (Asio accipitrinus).}

Resident and a winter visitor. It is now only a winter visitor to the local area. For eggs see Case 231, drawer 7. 


\section{Case 226.}

GOLDEN-EYE (Clangula glaucion).

A winter visitor to the British Islands and regularly seen in this district. For eggs see Case 231, drawer 36 .

\section{LONG-TAILED DUCK (Harelda glacialis).}

A winter visitor. There are a few local records only (Mitchell, p. 199, and Coward, p. 171). For eggs see Case 231, drawer 15.

GADWALL (Chaulelasmus streperus).

A winter visitor. Rarely seen in this district. For eggs see Case 231, drawer 11.

\section{POCHARD (Fuligula ferina).}

A resident species and winter visitor. Locally a winter visitor only, and it is rarely seen inland. For eggs see Case 231, drawer 15.

\section{PINTAIL (Dafila acuta).}

A resident and winter visitor. Regularly seen in this district during the winter months. For eggs see Case 231, drawer 13.

\section{GARGANEY (Querquedula circia).}

A summer resident and vagrant. Locally a very rare visitor. For eggs see Case 231, drawer 13.

\section{TUFTED DUCK (Fuligula cristata).}

A resident and winter visitor. Locally not uncommon, frequently seen on the meres and marshes. Fon egos see Case 231. drawer 15.

\section{SCAUP DUCK (Fuligula marila).}

A winter visitor. Regularly seen in this district. For eggs see Case 231, drawer 15 .

\section{HARLEQUIN DUCK (Cosmonetta histrionica).}

A very rare vagrant, and there are no authentic records of visits to this district. For eggs see Case 231, drawer 33.

\section{GOOSANDER (Mergus merganser).}

A resident and winter visitor. Occasionally seen in this district. For eggs see Case 231, drawer 14. 
Case 226-continued.

HOODED MERGANSER (Mergus cucullatus).

A very rare visitor from America. No local records.

SMEW (Mergus albellus).

A winter visitor. Locally very rarely seen.

EGYPTIAN GOOSE (Chenalopex ogyptiacus).

Many examples of this introduced species, an inhabitant of Africa and Palestine, have been killed in various parts of the country. There are several records of specimens shot on the Ribble, probably eseapes from confinement (Mitchell, "Birds of Lancashire," p. 5).

BERNACLE GOOSE (Bernicla leucopsis).

A winter visitor. Regularly visits this district, and is occasionally seen inland. Prior to 1862 it was common on the Dee marshes. Captain Congreve has one in his collection at Burton. C'heshire (Coward, "Birds of Cheshire," p. 157). For exgs see Case 231, drawer 36.

\section{BRENT GOOSE (Bernicla brenta).}

A winter visitor. Locally not uncommon. Visits the Dee Estuary in winter in considerable numbers. It is recorded that 200 were seen in 1888 hy Mr. A. O. Walter. Specimen at Burton, 1881. Mr. L. Jones shot one on Hilbre Island, 1895 (Coward, "Birds of Cheshire," p. 157).

\section{WHITE-FRONTED GOOSE (Anser albifrons).}

A winter visitol. Of fairly common occurrence locally in the winter months. For eggs see Case 231, drawer 36.

\section{BEAN GOOSE (Anser segetum).}

A winter visitor. Occasionally shot on the coasts of this district. One record on the Dee marshes, 1872 (coward, "Birds of Cheshire." p. 155). For eggs see Case 231, drawer 36.

\section{PINK-FOOTED GOOSE (Anser brachyrhynchus).}

A winter visitor. Regularly seen in this neighbourhood. For eggs see Case 231, drawer 36.

\section{MUTE SWAN (Cygnus olor).}

A. resident and generally distributed species in a semi-domesticated condition. Originally introduced. Locally common. For eggs see Case 231, drawer A. 
Case 226 -continued.

BEWICK'S SWAN (Cygnus bewicki).

A winter visitor. Fairly common in England and Wales. Very rarely seen locally.

\section{SHOVELLER DUCK (Spatula clypeata).}

A resident. Locally a winter visitor, but in small numbers. For eggs see Case 231, drawer 11.

\section{WIDGEON (Mareca penelope).}

A resident and winter visitor. Locally seen as a visitor only. For eggs see Case 231, drawer 13.

COMNION SCOTER (Edemia nigra).

A resident and winter visitor. Locally of common occurrence during the winter months. For eggs see Case 231, drawer 16.

\section{Case 227.}

CURLEW SANDPIPER (Tringa subarquata).

A passage-migrant, chiefly on the east coast. Fairly common locally in the spring and autumn.

GREAT SNIPE (Gallinago major).

A straggler to the British Islands in August to Uctober. It was first described by Peunant from a specimen shot in Lancashire (Mitchell, "Birds of Lancashire," p. 181). and has occurred on sereral orcasions in Lancashire and Cheshire. The specimen exhibited was shot at Winwick, Lancashire.

\section{JACK SNIPE (Gallinago gallinula).}

The .Jack Snipe is a winter visitor and fairly abundant locally. For eggs see Case 231, drawer 32.

TURNSTONE (Strepsilas interpres).

A passage-migrant and winter visitor. Fairly common locally. For eggs see Case 231, drawer 31.

GREY PHALAROPE (Plaalaropus fulicarius).

A rare and irregular passige-migrant. It is an irregular visitor to the local area. For eggs see Case 231, drawer 32. 
Case 227 - continued.

SPOT'TED SANDPIPER (Tringoides macularia).

An American bird whose appearances in the British Islands seem to he few ont of many dombthul records. There are, however, recorded

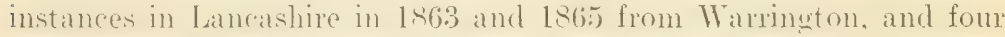

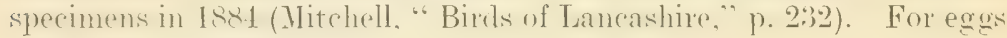
see Case 231, drawer 32.

RED-NE(KED PHALAROPE (Phalaropus hyperboreus).

A summer migrant and locally rare. Recorded once from Southport and eight times at Carnforth and Martin marshes ("History of Lancashire," p. 202). For eggs see Case 231, drawer 32.

\section{DOT'TEREL (Eudromius morinellus).}

A spring and autumn visitor. For eggs see Case 231, drawer 20.

\section{GREEN SANDPIPER (Totanus ochropus).}

A passage-migrant. occuring less frequently in the local area than on the east coast. For eggs see Case 231, drawer 32.

\section{KNO'T (Tringa canulus).}

A winter visitor, it is more abundant on the east coast, being a straggler to the local area.

\section{PURPLE SANDPIPER (Tringa striata).}

A winter visitor and widely spread over all our coasts, especially those of a sandy character. For eggs see Case 231, drawer 21.

\section{SANDERLING (Calidris arenaria).}

The Sanderling is a passage-migrant in April-May and in August to October, it is also a winter visitor, preferring sandy coasts.

\section{PTARMIGAN (Lagopus mutus).}

Resident in the north of Scotland. No local records. Specimens in winter and spring change of plumage are exhibited. For eggs see Case 231, drawer 34.

STONE CURLEW OR THICK-KNEE (.Edicnemus scolopax).

A rare resident in the British Islands. There is a specimen in the Warrington IIuseum, taken at IFoole, ('heshire (Coward, "Birds of Cheshire," p. 200). For eggs see Case 231, drawer 20. 
Case 227-continued.

SCLAVONIAN GREBE (Podicipes auritus).

A winter visitor. A few breed in the north mainland of Scotland, but there is no pronf that it breeds elsewhere in the British Islands. There are only a few recorts of its appearance in the local area. One was recorded at Burton in 1839 (Coward, "Birds of Cheshire," p. 250). For eggs see Case 231, drawer 33.

\section{RED-NECKED GREBE (Podicipes griseigena).}

A winter visitor, chiefly to the east coast of the British Islands. One is recorded as shot by . Ir. Lewis Jones, at Hilbre Island, in the estuars of the river Dee, Cheshire (Coward, "Birds of Cheshire." p. 249).

EAPED or BLAC'K-NECKED GREBE (Podicipes nigricollis).

A resident and visitor to the British Islands. In the local area one was secured near the mouth of the river Lume, Lancashire, in March or April, 1286 (Mitchell, "Birds of Lancashire," p. 262) ; one was shot at Bagilt, Dee estuary, on the 27th September, 1856 (Coward, "Birls of Cheshire," p. 250); and an adult male in full summer plumage was captured alive at Middleton, near Lancaster, on the 28th July, 1904 ("Zoologist," 1901, p. 350). A specimen caught in a fishing net on the Merser, near Trammere, in 1897, is now in the Chester Museum. For eggs see Case 231, drawer 24.

\section{PALLAS'S SAND GROLSE (Symhaptes paradoxus).}

An irregular visitor to the British Islands; the greatest numbers occurred in May, 1863, and in 1888. Of the specimens in the case the male with the wings closed is from Tremadoc. Torth Wales, July 8th, 1859 ; it is one of the first examples known to be taken in Europe. The male with open wings was taken at Hovlake in 1863 , and the female at Storeton, July 1st, 1888.

\section{QUAIL (Coturnix communis).}

This species is resident in the British Islands, with additional visitors in spring. Although once a common visitor to this district, it is now rare, and only seen at irregular intervals. For eggs see Case 231, drawer 18.

\section{SPOTTED CRAKE (Porzana maruetta).}

A spring visitor to the British Islands. There were three occurrences recorded in 1898, and one in 1904. all in the Rusland Tailey, Furness, Lancashire (" Zoologist, 190t, p. 160). For eggs see Case 231 drawer 19 . 
Case 227 -continued.

LITTLE AUK (Mergulus alle).

An irregular winter visitor, occasionally met with in the local area. For eggs see Case 231, drawer 33.

\section{GREAT AUK (Alca impennis).}

The Great Auk (now extinct) used to breed in St. Kilda, but even by the middle of the 1Sth century the birds had become very irregular in their visits. The bird made no nest, but the single egr was laid on the bare rock. The IIuseum possesses a good example of the Great Auk's Egg.

The exhibited specimens include the skull of the Great Auk, photographs of the restoration of the bird and an egg in the possession of the Norwich Corporation, and a case of an egg (see ('ase 231, drawer A).

\section{LITTLE STINT (Tringa minuta).}

The Little Stint visits the British Islands in the spring and in the autumn on its migrations to and from the North. It is occasionally met with in the estuaries of the Dee and Mersey in the autumn.

\section{TEMMINCK'S STINT (Tringa temmincki).}

Temminck's Stint is a rare and irregular migrant, chiefly in autumn, and is very rarely met with in the spring. In the local area it is, recorded from Ribbleton IIoor, 1864. Pilling, 1873 (Mitchell, "Birds of Lancashire," p. 191), and the Dee Marshes near Shotwick, 1862 (August) (Coward, "Birds of Cheshire," p. 215). For eggs see Case 231, drawer 32.

\section{GREY PLOVER (Squatarola helvetica).}

A winter visitor to the local area.

\section{AVOCET (Recurvirostris avocetta).}

The Avocet was formerly one of our regular summer migrants, but it is now merely a straguler. It has occurred in the local area on Walney Island and on the Ribble. For eggs see Case 231, drawer B.

\section{WOOD SANDPIPER (Totanus glareola).}

A jassage-migrant and a rare autumn and winter straggler to the local area. For eggs see Case 231, drawer 21. 
Case 227-continued.

COLLARED PRATINCOLE (Glareola pratincola).

The Collared Pratincole is an African species, and occasionally, visits the British Islands in the spring and autumn. The bird in the case is the first recorded British specimen, and was taken at North Meols, Lancashire, in 1803.

WHIMBREL (Numenius phoopus).

A summer resident and passage-migrant. In the local area it visits Morecambe Bay. For eggs see Case 231, drawer 21.

BAR-TAILED GODWIT (Limosa lapponica).

A winter visitor and passage-migrant.

BLACK-TAILED GODWIT (Limosa belgica).

An irregular migrant. and more rarely met with than the Bar-tailed Godwit. For eggs see Case 231, drawer 21.

\section{DUNLIN (Tringa alpina).}

A resident and winter visitor. The specimens here shown are in winter plumage. For eggs see Case 231, drawer 21.

\section{SPOTTED REDSHANK (Totamus fuscus).}

An uncommon passage-migrant, rare to the local area. A specimen taken at Southport is in the Sturly Collection. For eggs see Case 231, drawer 32.

GREENSHANK (Totanus nebularis).

The Greenshank is a resident in the British [slands, and breeds in Scotland. It is sparsely distributed in the local area.

\section{GLOSSY IBIS (Plegadis falcinellus).}

Common in Southern Europe, but only an accidental visitor to Great Britain in autumn or early winter ; observed on four occasions in Lancashire during the past century. The specimen sliown was shot at Ormskirk over 62 years ago. No records in Cheshire.

\section{Case 228.}

\section{SANDWICH TERN (Sterna cantiaca).}

A summer visitant. At one time it bred freely on Walney Island. (Mitchell, "Birds of Lancashire." p. 208). For egggs see Case 231, drawer 22. 
Case 228-continued.

\section{BLACK TERN (Hydrochelidon nigra).}

A passing migrant. Few local records one at Ashton-on-Mersey. November 3, 1893 ("History of Lancashire," p. 203).

\section{IVORY GULL (Pagophila eburnea).}

This species appears on the Northern coasts when severe winters have driven it from Spitzhergen and the neighbourhood. Locally it is said to have been killed on several occasions in .Iorecambe Bay (!). and one was taken at Kendal and one at Carnforth ("Fauna of Lakeland," p. 438).

\section{GLAUCOUS GULL (Larus glaucus).}

This species is the "Burgomaster" of the whalers. It is distinguished by its enormous spread of wings, being one of the largest of the gulls. It is only an irregular visitor, and very rare to this locality.

\section{POMATORHINE SKUA (Stercorarius pomatorhinus).}

A passage-migrant and winter visitor. It fairly regularly makes its appearance in the district.

\section{POMATORHINE SKUA AND COMMON GULI.}

These specimens were shot in the Nersey in the circumstances shown in the case. While in flight the Skna is forcing the (tull to release its freshly-caught prey, which the Skua in turn by a sudden dive catches before it reaches the sea.

\section{GREAT SKUA (Megalestris catarrhactes).}

This species is resident in the Shetlands. It is locally known as the "Sea Hawk," and not a common visitor to this district. For eggs see Case 231, drawer B.

\section{RICHARDSON'S SKUA (Stercorarius crepidatus).}

A summer resident and passing migrant. Not uncommon locally. For eggs see Case 231, drawer 23.

\section{BUFFON'S SKUA (Stercorarius parasiticus).}

Irregular autumn migrant, locally a rare visitor. For eggs see Case 231, drawer 33.

\section{LITTLE GULL (Larus minutus).}

Irregular autumn and winter visitor. It has been seen on rare occasions in this district during the winter. 
Case 228-continued.

\section{BITTERN (Botaurus stellaris).}

A winter visitor chiefly, but in some districts is seen also in summer.

GREAT NORTHERN DIVER (Colymbus glacialis).

A winter visitor. Most plentiful in the North. Locally only occasionally recorded. For eggs see Case 231, drawer 24.

CORIIORANT (Phalacrocorax carbo).

A resident, generally distributed. May be seen occasionally in the Mersey Estuary. For eggs see Case 231, drawer 10.

STORMY PETREL (Procellaria pelagica).

A resident, locally sometimes seen after storms. For eggs see Case 231, drawer 27.

\section{MANX SHEARIVATER (Puffinus anglorum).}

A resident and a winter visitor to this district. For eggs see Case 231, drawer 27.

\section{FULMAR PETREL (Filmarus glacialis).}

A resident. Locally of very rare occurrence. For eggs see Case 231, drawer 27.

LEACH'S PETREL (Procellaria leucorrhoa).

A straggler, breeding at St. Kildat. Locally it has only been recorded during stormy weather. For eggs see Case 231, drawer 27.

WILSON'S PE'TREL (Oceanites oceanicus).

Very rare vigrant. The only local record is of one washed ashore, Walney Island, November, 1890 ("Fauna of Lakeland," p. 457).

The following additional birds have been occasionally recorded in Lancashire and Cheshire, and representative specimens are contained in the Study Collection, and may be seen on application :-

Blue-headed Wagtail (Motacilla flava).

Black-throated Wheatear (Saxicola stapazina)

Fire-crested Wren (Regulus ignicapillus).

Richard's Pipit (Anthus richardi).

Woodchat (Lanius pomeranus). 
White-bellied Swift (alpine) (Cypselus melba).

Roller (Coracias garrulus).

Spotted Eagle (Aquila clanga).

Red-footed Falcon (Tinnunculus vespertinus)

Purple Heron (Ardea purpurea).

Little Bittern (Ardea minuta).

Night Heron (Nycticorax griseus).

American Bittern (Botaurus lentiginosus).

Spoonbill (Platalea leucorodia).

Whooper Swan (Cygnus musicus).

White-eyed Duck (Nyroca ferruginea).

Velvet Scoter (Edemia fusca).

Surf Scoter (Edemia perspicillata).

Baillon's Crake (Porzana bailloni).

Little Crake (Porzana parva).

Crane (Grus communis).

Little Bustard (Otis tetrax).

Sociable Plover (Vanellus gregarius).

Buff-breasted Sandpiper (Tringites rufescens)

Red-breasted Snipe (Macrorhampus griseus).

Roseate Tern (Sterna dougalli).

Gull-billed Tern (Sterna anglica).

White-faced Petrel (Porcellaria marina).

Sabine's Gull (Xema sabinii).

Iceland Gull (Larus leucopterus).

\section{Case 229.}

The specimens in this case are designed to show the remarkable changes in the plumage of many birds, according to age and season. Tany gulls, for example, differ so much from year to year in the first four or five year's of life that birds of the same species during this period are often mistaken for different species. Some species of birds have a summer or breeding plumage, which is quite different to the winter plumage, and males are often very different from females.

RED-THROATED DIVER (Colymbus septentrionalis).

Four specimens to illustrate the stages in the change of plumage of this species from the chick to the adult. The complete breeding plumage of this species may be seen in the group, Case 217.

\section{BLACK GUILLEMOT (Uria grylle).}

Ten specimens showing the stages in the change of plumage from the chick to the adult summer plumage, and from this to the winter plumage. The first plumage of the young Black Guillemot, 
Case 229 -continued.

with the exception of the white patch on the wings, which is here mottled, resembles the winter plumage of the adult, so that with this exception the changes here shown are undergone each year in both sexes.

\section{HERRING GULL (Larus argentatus).}

The front six specimens of this species illustrate the yearly change of plumage from the chick to the adult in five vears. The two specimens at the back are intermediate stages of the third year.

KITTIWAKE GULL (Rissa tridactyla).

Contrast of immature and adult plumage.

\section{GREAT BLACK-BACKED GULL (Larus marinus).}

A specimen in immature plumage. The adult may be seen in the group of the Great Black-backed Gull, Case 208.

\section{EIDER DUCK (Somateria mollissima) (male).}

Six specimens showing the gradual change in the moulting from the dark brown to the full adult male plumage.

\section{Case 230.}

\section{Domesticated Birds.}

A case of specimens illustrating recognized varieties of birds in domestication, which have been derived by artificial selection from ancestors in a state of nature.

\section{THE COMNON CANARY (Serinus canaria).}

Ahout twenty recognized varieties of the Common Canary have been produced from it by artificial selection and pedigree breeding. Of these many are shown by prize or exhibition specimens, so that the points of each fancy are well displayed.

There are also several specinens of hybrids produced by crossing with Finches, and by other crosses.

\section{THE ROCK PIGEON (Columba livia).}

There are upwards of 200 varieties of Domestic Pigeon, all produced by artificial selection from a common ancestor, the Rock Pigeon. A few of the more well-marked varieties are here on exhibition, sufficient to show the extreme types of rariation brought about. Many of these specimens are prize birds, most typical of the fancy they represent. 
Case 230-continued.

Varieties of the Domestic Fowl, Pheasant Hrbrids and several Fighting (Game ('ocks of historical interest from having fought in this district, are exhibited

A specimen of Black Grouse (Tetrao tetrix) that has assumed male phumage is also on view. This is a variation that is somewhat common among Game Birds.

\section{Case 231.}

\section{Cabinet of Eggs of British Birds.}

In this Cabinet are specimens of the eggs of British Birds, arranged in their respective clutches, including all the nesting species and most of the birds that visit the British Islands. The birds that breed and build nests in the neighbourhood are distinguished by a red asterisk.

A liey list of the birds is placed over the case, arranged alphabetically with cross references, giving the number of the drawer opposite each bird, in which its eggs may be found.

\section{Case 232.}

\section{A case arranged to facilitate the comparative study of Birds' Eggs.}

(a) Structure of egg shell and the surface grain or texture of eggs.-

The egg shell is composed of carbonate of lime which is secreted by the shell gland and spread over and around the egg shortly before the egg is laid. (Hence the necessity for lime salts in the food of birds generally).

In certain families the egg shell exhibits a definite grain or texture and in some cases species of the same genus are so distinguished. Exanples of this latter condition, which may be called specific differences are seen in the difference between the Trumpeter Swan (1) and Mute Swan (2), or hetween the Grey Lag Goose (3) and Pink-footed Goose (4), examples of which are shown.

According to appearance, eggs may be grouped under the following heads: Smooth, Glossy, Porcellanous, Greasy, Chalky film, Dull and Granulated.

Smooth Variety. The majority of birds lay eggs with a smooth surface. Examples shown are Pheasant (5), Red Legged Partridge (6), Moor Hen (7). Golden Plover (8), (Oyster Catcher (9). Song 'Thrush (10), Jay (11). Skylark (12), Butcher Bird (13), and Wheatear (14).

*The numbers here given are the numbers of the specimens in the Case. 
Case 232-continued.

Glossy Variety. Examples of this variety, which in addition are usually colourless, thin and semi-transparent are seen among others in Woodpeckers, one of which, the Green Woodpecker (15) is shown.

Porcellanous Variety. The Tinamous, Central and South American Birds are good examples, the shells of which are thick. oparue and so highly glazed as to have a burnished appearance. Specimens of the birds may be seen in the Upper Gallery, and its eggs are shown in this Case (16).

Greasy Variety. All ducks have eggs with a greasy or oily appearance, i.e., Mallard (17), Eider Duck (18), and MLerganser (19).

Chalky-film Variety. Some eggs are covered with a chalkyfilm, for example the Flamingo (20), Cormorant (21) and Grebe (22). It is suggested that this covering serves as a protection against too much damp-Grebes for example build over water.

Dull V'ariety. Many eggs are without polish or lustre, i.e., the Black Guillemot (23) and Kestrel (24).

Granulated Variety. Examples of this variety are best exhibited by egus of many of the Rumning Birds -Emu (25) and ('assowary (25a) but there are others such as the ciuinea Fowl (26) and Francolin (27), which present quite a granulated appearance.

\section{(b) Colouring of Eggs。-}

The pigment of birds' eggs is on the surface and is deposited immediately before it is laid. Almost every shade of colour is represented, and a sufficient explanation of its meaning is not always fortheoming. In many instances the colour markings are undoubtedly protective. Generally speaking eggs that are laid in the open. with little or no covering or the protection of a nest, have their colour markings harmonising with the colour tones of their surroundings, rendering them so inconspicuous that they are not seen by a casual observation, i.e., the Terns (see Case 202), the Lapwing and Snipe (see (ase 201), the Ptarmigan and Grouse. Again it is suggested that the reason of the light colour or whiteness of the eggs of many birds that build in dark places, i.e., the Starling (see ('ase 109), the Sind Martin (see (ase 15.4), the Kingfisher (see Case 157), and the Stock Dove (see Case 224) is that the eggs may be easily found by the parents, hut there are many exceptions to this.

The eggs of young birds are usually not so richly coloured as when the birds are in their prime, and when old age advances the colours again become less brilliant. Examples are here shown 
Case 232 - continued.

taken from various clutches, viz., House sparrow (28), R obin(29), Sparrow Hawk (30), Buzzard (31), and Lapwing (32), in which the variations seen are probably due to the difference in age of the parent of each egg. Eggs of the same clutch however, often vary, i.e., clutch of Lesser Tern (33). Two complete clutches of Lapwing eggs are also shown, one (32a) being all normal in colour, whereas the other $(32 b)$ are abnormal in colour. But perhaps the most striking example of the variations exhibited by eggs, not only of the same species, but even of the same bird is that of the Guillemot, in which no two eggs are quite alike. An interesting series of these eggs may be seen in the Egg Cabinet (Case 231, drawers 25 and 26).

\section{(c) Clutches. -}

The set of eggs which a bird lays for each setting is called a clutch. The number of such a full clutch varies in different species, from one to as many as twenty. In many groups of birds the number of the clutch is constant and distinctive of the species. The following examples are given :-

One. Where a clutch consists of only one egg it is generally large in comparison with the hird, i.e., Guillemot (34), Puffin (35), and Stormy Petrel (36).

Two. Two eggs clutches are very common and constant Examples shown-Dove (37). Nightjar (38), Diver (39), and Buzzard (40).

Two to Three. Hany birds are variable, sometimes two, sometimes three to the clutch, i.e., Herring (xull (41), Kittiwake (42). Skua (43) and Common Tern (44).

Four. This is a very constant number among Plovers, etc., i.e.. Ring Plover (45), Sandpiper (46) and Common Snipe (47).

Four to Seven. The Perching Birds are mostly included in this series, i.e., Song Thrush (48), Greenfinch (49), Yellow Bunting (50) ant swallow (51). I few however, as the Tits, lay as many as ten or twelve eggs.

Ten to Fifteen. Nearly all the Game Birds, Rails and Ducks, lay from ten to fifteen eggs to the clutch, sometimes more. Examples given are the ('ommon Partridge (52) and Joorhen (5.3)

The Cuckoo lays several eggs during the season, but only one is deposited in each nest of the foster mother. For further account of the Cuckoo see description of groups under Cases 159-161. 
Case 232-oontinued.

\section{(d) Size of Egg.-}

Eggs vary much in size, for example note the egg of Ostrich (54) and Humming Bircl (55). A large exg usually means that the young chick is hatched in it less helpless condition than from the small egg; as a much larger amount of food rolk is present, the incubating period is longer and the chich is mure dereloped when hatched. Generally but nut it all constantly, the size of the egg is proportional to the parent as the utmilser of euge to ise curered by cue bird inust be considered. The fullowing examples illustrate the size of eggs in comparison to that of the parent.

The egy of the partrielge (5) alt hongh at muth latger bird is nu larger than the egg of the Snipe (5) . Igain the Blackbird's egg (58) is much smaller than the Snipe, although the birds are about equal in weight. The young Blackbirds are helpless when hatched, but the young snipe are able to run about immediately. The ('nekon and Ilissel Thrush are of equal size. but the egg of the former (Cuckoo 59) is much smaller than the latter (Missel Thrush (j0), and is but slightly larger than the sparrow's fogg (61). Again the Guillemot egg (62) is considerably larger than the Raven (63) although the birds are about equal in size, whereas the Imperial Eagle is five or six times larger than the fruillemot. hut its egg (64) is no larger.

\section{(e) Form of Eggs.-}

The shape of the eggs is fainly constant in the various groups of birds. The principal varieties may be classed under the following heads :-Ovoid, Pyriform, Bi-conical, Oval, and Spherical.

Ovoid. This is the most common and familiar form-that of the (ommon Fowl. Nearly all (ame Birds. Gulls. Ducks and Perching Birds have this type of egg. Examples shown are Partridge (65), Great Black-backed Gull (66), Jackdaw (67) and Nightingale (68).

Pyriform. The pear shaped eggs are characteristic of Snipe, Plovers, ete., the Guillemot and Great Auk. The pyriform shape of egg is especially useful where little or no nest is made, and its shape causes it to roll in small circles if disturbed. The examples of this variety shown are-Godwit (69), Ring Plover (70), Lapwing (71), and Guillemot (72).

Bi-conical. Eggs pointed at both ends are characteristic of the Grebes, i.e., Great Crested Grebe (73) and Little Frebe (7t). 
Case 232-continued.

Oral. The eggs of the Nightjar (75) have both ends equally rounded, forming a true oval.

Spherical. Nearly round or spherical eggs are characteristic of the 0 wls and a few other groups. The eggs uf birds of prey approach this form. Examples shown ure Tawny Owl (76). Barn OwI (77). Lingfisher (78). Osprey (79), Herhn (30) and Sparrow Hawk (81)。 
Index and reference List of the British Birds on Exhibition with the common names arranged alphabetically.

\begin{tabular}{|c|c|c|c|c|c|}
\hline & & & & No. OF & \\
\hline & CASE. & P.IGE. & & CASE. & PAGE \\
\hline vocet & 227 & 56 & Duck, Long-tailed....... & 226 & 51 \\
\hline Auk, Little & 227 & 56 & , Pin & 226 & 51 \\
\hline Auk, Creat & 227 & 56 & $\begin{array}{ll}. & \text { Poc } \\
. & \text { Sca }\end{array}$ & $\begin{array}{l}-296 \\
226\end{array}$ & 51 \\
\hline Bittern, Common .......... & 228 & .5) & She & 196 & \\
\hline 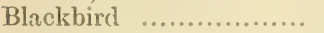 & 177 & 26 & Sh & 226 & 53 \\
\hline reap.................... & 163 & 21 & Ter & 194 & 32 \\
\hline tock.................. & 221 & 14 & 'l'u & 206 & 51 \\
\hline g $\ldots . . . \ldots \ldots \ldots \ldots . .$. & 225 & is & , & 226 & 53 \\
\hline & 11 & $\therefore$ & , IVild or Mallard & 195 & 32 \\
\hline unting, Cirl $\quad$............. & 12 & 111 & IJunlin................ 201 , & .227 & 5.5 \\
\hline " Corn ............. & 12 & 9 & & & \\
\hline Lapland $\quad . . . .$. & 12 & 111 & Eagle, Golden & 189 & 30 \\
\hline $\operatorname{lan} . . . . . .$. & & 11 & - & & \\
\hline (n........ & 12 & 9 & Egg Cabir & 231 & 02 \\
\hline v $\ldots \ldots \ldots \ldots$ & 12 & 111 & . Sturly. & 232 & (i:2 \\
\hline Yellow .......... & 12 & 10) & & & \\
\hline Buzzard, Common ...... & 187 & 29 & Falcon, Greenls & & 49 \\
\hline$" \quad$ Hon & 22 & $+!$ & , Peregrine........ & & \\
\hline h-legged & 225 & 4) & $\begin{array}{l}\text { Fieldfare } \\
\text { Flycatcher, Pied .......................... }\end{array}$ & $\begin{array}{l}225 \\
225\end{array}$ & \\
\hline nercaillie & 223 & $41 i$ & "Spo & 143 & 14 \\
\hline 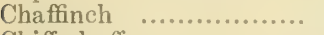 & 11 & $\bar{j}$ & & & \\
\hline 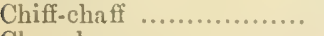 & 167 & 23 & Gan & $1 !$ & 30 \\
\hline gh $\quad \ldots \ldots \ldots \ldots \ldots \ldots \ldots$ & 10 & 3 & sucker & 166 & 22 \\
\hline oot................ 213, & 213 & 4 & Godwit, Blac & 227 & 57 \\
\hline orant .................. & 22 & ¿!! & & 227 & 57 \\
\hline (............... & 222 & Hi & Goldfinch & 116 & 6 \\
\hline Spotted ............. & 227 & 55 & nder $r$ & $2:-1$ & .31 \\
\hline Crossbill .................... & 12 & s & Goose. Be & $226 i$ & 52 \\
\hline Crow, Carrion ............. & & 1 &,$\quad B e$ & 226 & 52 \\
\hline "Hooded .............. & & 2 &, & 226 & 52 \\
\hline 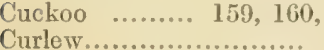 & & 20,2 & , & & 52 \\
\hline 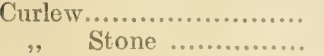 & & 44 & , & 192 & 31 \\
\hline$" \quad$ Stone ................ & 227 & 54 & . $\quad \mathrm{Pi}_{\mathrm{I}}$ & $\begin{array}{l}2216 \\
226\end{array}$ & 52 \\
\hline ipp & & $1 !$ & Goshawk & 225 & 50 \\
\hline Diver, $\mathrm{B}$ & & 42 & Grebo, Ear & & \\
\hline " $\quad$ Gt. Northern $\quad$ Red-throated & & & & 227 & 55 \\
\hline $\begin{array}{l}\text { Red-throated } 216 \text {, } \\
\text { Domesticated Birds }\end{array}$ & 229 & 42,60 & rested & 21 & 41 \\
\hline $\begin{array}{l}\text { Domesticated Birds ....... } \\
\text { Dotterel ...................... }\end{array}$ & & (i) & .. & $21, i$ & 41 \\
\hline $\begin{array}{l}\text { Dotterel ........... } \\
\text { Oove, Rock ... }\end{array}$ & & .it & $\operatorname{Re}$ & 227 & 55 \\
\hline $\begin{array}{c}\text { ove, } \\
\text { ", Rock } \\
\text { Ring ... }\end{array}$ & 22 & 43 & n or & & \\
\hline$", \quad 1$ & & 16 & & 227 & 5. \\
\hline (n......... & & 46 & reenfinch & 112 & $\underline{5}$ \\
\hline non Scoter & $\begin{array}{l}218 \\
226\end{array}$ & $\begin{array}{l}43 \\
53\end{array}$ & Grosbeak, & 225 & $\begin{array}{l}5 i \\
49\end{array}$ \\
\hline " Eide & 229 & 31. 61 & Grouse, Red & 221 & 4 \\
\hline ................ & & 51 & B] & 230 & 44,62 \\
\hline ney leal ... & & 51 & "Pallas's Sand & 227 & \\
\hline Golden Eye ...... & 226 & 51 & Guillemot, Black..... 210, & 229 & 39, 60 \\
\hline Harlequin ......... & 226 & $5 !$ & $" \quad$ Common $\quad \cdots$ & 212 & 40 \\
\hline
\end{tabular}




\begin{tabular}{|c|c|c|c|c|c|}
\hline & $0.0 \mathrm{~F}$ & & & NO. OF & \\
\hline ull, Black-headed. & ASE. & $\begin{array}{l}\text { PAGE. } \\
37\end{array}$ & Owl Scons & $\begin{array}{l}\text { CASP: } \\
2.25\end{array}$ & $\begin{array}{l}\text { PACF. } \\
50\end{array}$ \\
\hline , Common......... 206, & 228 & 38,58 & ,Short-eared & 2.25 & 50 \\
\hline "Glaucos .............. & 228 & is & "Snowy ....... & 2.25 & 50 \\
\hline Great Black-backed & & & , Tawny ...... & lsl & 27 \\
\hline 208 & $2: 29$ & 39,61 & .. Tengmalm's & 225 & 511 \\
\hline "Herring........ 207, & 229 & 38,61 & Oyster-catcher ... & 198 & 33 \\
\hline$"$ Ivory .............. & $\begin{array}{l}228 \\
229\end{array}$ & 38.61 & Partridge, Common & .2 .2 & $+j$ \\
\hline "Lesser Black- & & & .. Red-legged .... & 219 & 43 \\
\hline backer & 204 & 37 & 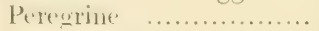 & $180^{\circ}$ & 28 \\
\hline Little & 228 & 58 & Petrel, Fulmar & 2.25 & 59 \\
\hline arrier, Неn ...... & 22,5 & & or Little & $\log _{0.25}$ & 59 \\
\hline , Marsh .................... & 225 & $\tilde{i n}$ & $\begin{array}{l}\text { Stormy or Little } \\
, .\end{array}$ & 2.28 & in \\
\hline " Montague's ... & 225 & 49 & Phalarope, Grey ...... & $2-27$ & .3 3 \\
\hline Hawfinch ................. & 121 & S & .. Red-necked & 207 & 54 \\
\hline Hawk, Sparrow .......... & 183 & 27 & P'hea-ant.................... & $2: 2 \cdot 2$ & 4.5 \\
\hline ge Accentor .... & 173 & 24 & Pipit, Meadow & $1: 30$ & 11 \\
\hline on $\ldots \ldots \ldots \ldots \ldots$ & 200 & 31 & , Rock . & 1:31 & 11 \\
\hline by $\ldots \ldots \ldots \ldots \ldots \ldots \ldots$ & 225 & 51) & .. Tre & $12 ! 9$ & 11 \\
\hline oорое ................. & 225 & 48 & Plover, Golden & 201 & 35 \\
\hline ney-buzzard.. & 225 & +9 & .. (ire & 27 & 56 \\
\hline , Glossy & 227 & 57 & ratinco & 202 & 37 \\
\hline & 20 & 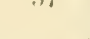 & Ptarmig & 227 & it \\
\hline ackdaw $\quad \ldots$ & 105 & 3 & Puffin .. & 209 & 39 \\
\hline$\ldots \ldots \ldots+\ldots \ldots+\cdots \cdots+\cdots$ & 108 & t & & & \\
\hline rel & 185 & 28 & & $2 \ldots$ r & $\therefore$ \\
\hline fisher. & 157 & 19 & Rail, Land & 22.2 & 46 \\
\hline ite $\quad . . . . .$. & 225 & 49 & Water & 215 & 42 \\
\hline not $\ldots . .$. . & 227 & $5+$ & Raven & 103 & 2 \\
\hline & & & Razorlill.... & 211 & 40 \\
\hline apwing . & 201 & 35 & Redpoll, Lesser . & 112 & 6 \\
\hline ark, Sky ....... & 128 & 40 & ., Mealy & 225 & 49 \\
\hline ", Shore .... & 225 & 18 & Redshank, Common & $19 !$ & $3 t$ \\
\hline ,. Wood ............... & 118 & 7 & , Spotted .. & 227 & 57 \\
\hline Linnet ........... & 115 & ti & Redstart, Common ...... & 170 & 24 \\
\hline agpie & 107 & $t$ & .... & 225 & $\begin{array}{l}47 \\
47\end{array}$ \\
\hline$d \quad . . . . . . . .$. & 195 & 32 & Ouzel .. & 176 & 25 \\
\hline artin, House . & 152 & 17 & n. & 169 & 23 \\
\hline , Sand .......... & 154 & 18 & Rook ....................... & 101 & 1 \\
\hline Merganser, Hooded .... & 226 & 52 & Rose-roloured Pastor ... & $22 \pi$ & 47 \\
\hline " Red-breasted & 197 & 33 & Ruff $\quad \ldots \ldots \ldots \ldots \ldots \ldots \ldots \ldots$ & 106 & $: ;$ \\
\hline Moorhen $\quad \cdots . . . . .$. & $\begin{array}{l}184 \\
214\end{array}$ & 28 & & 227 & 54 \\
\hline & & & Sandpiper, Common ... & 199 & 34 \\
\hline & & 22 & ,, Curlew......... & 227 & 53 \\
\hline & & $m^{2}+2$ & rireen. & 227 & 51 \\
\hline racker..... . & 225 & 47 & Purplo .. & 227 & 54 \\
\hline & 145 & 15 & Spotted.... . & 2.27 & 54 \\
\hline Golden & 225 & 48 & ................. & 191 & 31 \\
\hline & 188 & 30 & hearwater, Manx.......... & $22 \mathrm{~s}$ & 59 \\
\hline Ouzel, Ring & 176 & 2.5 & Sheldrake ................ & 196 & 33 \\
\hline 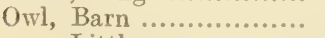 & 180 & 26 & Shrike, Great Grey ...... & 225 & 48 \\
\hline , Little ............... & 225 & 50 & " Red-backed ....... & 123 & 9 \\
\hline " Long-eared & 182 & 27 & Siskin . & 117 & 7 \\
\hline
\end{tabular}




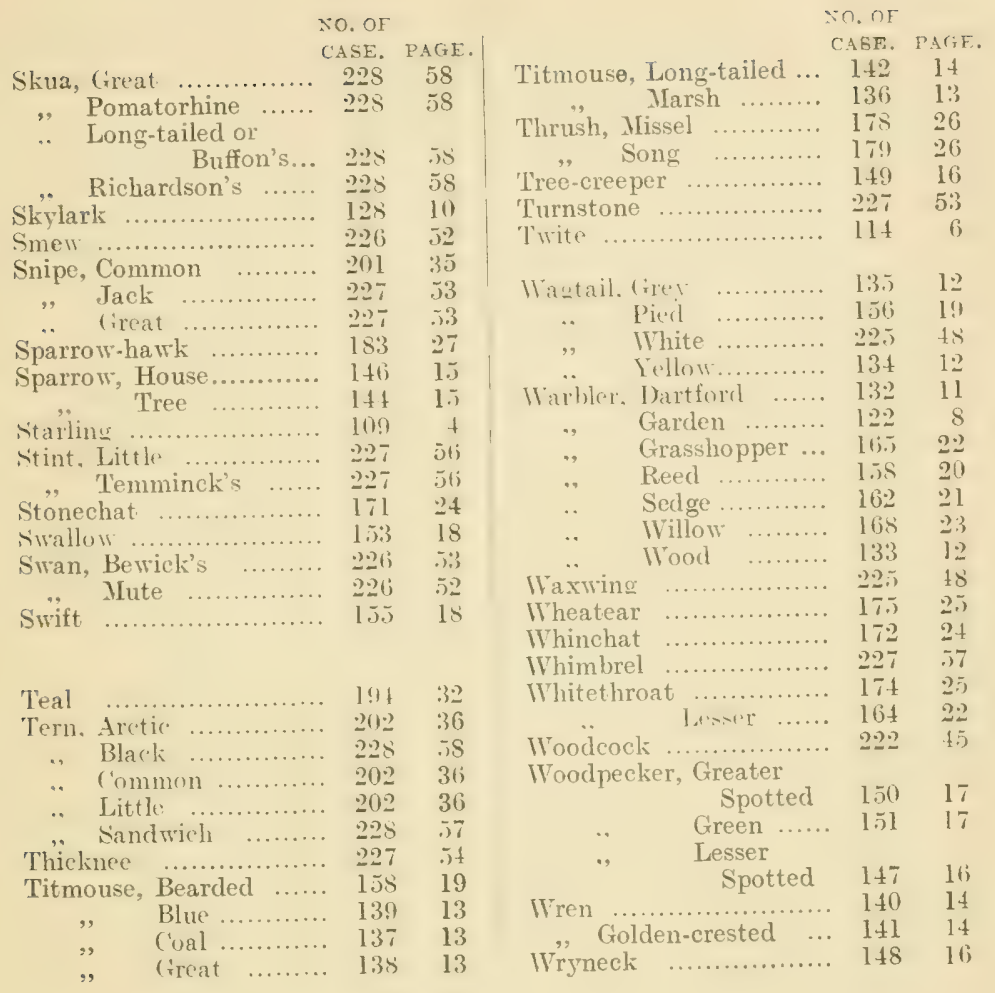








\section{FREE PUBLIC MUSEUMS, LIVERPOOL.}

\section{DAYS AND HOURS OF ADMISSION.}

January - - - from 10 a.m. to 4 p.m. February - - - " " 4.30 , March - - - " " 5 " April to September - " , " 6 " October - - - " " 5 " November and December , " " 4 "

The Museums are closed on Sundays and Public Fast Days. Tuesdays are reserved for Students and Special Visitors on application.

By Order,

JOSEPH A. CLUBB, Curator of Museums. 